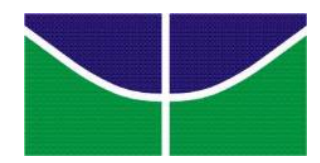

UNIVERSIDADE DE BRASÍLIA - UNB

INSTITUTO DE LETRAS - IL

DEPARTAMENTO DE LINGUÍSTICA, PORTUGUÊS E LÍNGUAS CLÁSSICAS - LIP PROGRAMA DE PÓS-GRADUAÇÃO EM LINGUÍSTICA- PPGL

ESTRUTURA ARGUMENTAL E ORDEM DOS TERMOS NO PORTUGUÊS L2 (ESCRITO) DE SURDOS

Hely César Ferreira

Brasília/DF

2016 


\title{
ESTRUTURA ARGUMENTAL E ORDEM DOS TERMOS NO PORTUGUÊS L2 (ESCRITO) DE SURDOS
}

\author{
Hely César Ferreira
}

Dissertação apresentada ao Departamento de Linguística, Português e Línguas Clássicas do Instituto de Letras da Universidade de Brasília como requisito parcial à obtenção do título de Mestre em Linguística.

Área de concentração: Teoria e Análise Linguística

Orientadora: Prof ${ }^{\mathrm{a}}$. Dr ${ }^{\mathrm{a}}$. Heloísa Maria Moreira Lima de Almeida Salles. 
Dissertação de autoria de Hely César Ferreira, intitulada "Estrutura argumental e ordem dos termos no português L2 (escrito) de surdos", requisito parcial para obtenção do grau de Mestre em Linguística, defendido e aprovado, em 26 de julho de 2016, pela banca examinadora constituída por:

Heloísa Maria Moreira Lima de Almeida Salles

(Orientadora e presidente - PPGL/LIP/UnB)

Rozana Reigota Naves
$($ membro interno - PPGL/LIP/UnB)

Déborah Christina de Mendonça Oliveira

(membro externo - UCB)

Paulo Medeiros Júnior

(membro suplente - LIP/UnB) 


\section{Dedicatória}

À minha família, em especial, a mais nova integrante: Geyse Araújo Ferreira. 


\section{AGRADECIMENTOS}

Agradeço primeiramente a Deus, Pai Eterno e Mentor de todas as minhas ações, que me proporcionou sabedoria e clareza nos meus atos, orientou meus estudos e me deu forças para nunca desistir dos meus ideais;

À minha querida professora Heloísa Salles, orientadora da Dissertação de Mestrado, pelas discussões, ensinamentos e incentivo a essa pesquisa;

Aos meus pais, Ilidio e Almerinda, aos meus irmãos Edson e Sueli, aos meus sobrinhos Lhorena, Thiago Henrique e Isabella, que estiveram ao meu lado nos momentos de que precisei por todo o amor, apoio e sabedoria ensinados a mim;

À minha querida esposa Geyse, companheira para todos os momentos, carinhosa, amorosa e divertida. Mulher escolhida por Deus para ser o amor da minha vida, criar uma família e para compartilhar todos os momentos. Obrigado por todo o apoio que você me dá que esteve junto comigo para me alegrar e me distrair nos momentos de ansiedade, estresse e nervosismo;

Aos amigos surdos Charley, Carolina Resende, desde a graduação, que esteve ao lado dos encontros importantes para me dedicar aos meus estudos e os bons momentos vividos jamais serão esquecidos!

À intérprete de LSB/LP, Fabiane Pagy, o qual colaborou na transcrição dos dados linguísticos deste trabalho;

Aos companheiros pela visita de escola, à diretora Florence Alves, à coordenadora pedagógica Vivian Zerbinatti, aos professores Marília, Renata, Maria de Lourdes, pela disponibilidade em acompanhar o trabalho apontando revisões e sugestões. 
"Um homem não tem que fazer tudo, mas algo, e não é porque não pode fazer tudo que precisa fazer este algo de maneira errada".

Henry David Thoreau 


\section{RESUMO}

Este trabalho tem o objetivo de analisar a expressão sintática da estrutura argumental na gramática da língua portuguesa na interlíngua de surdos aprendizes do português L2 e verificar como ocorre a aquisição dessas estruturas, tendo em vista a hipótese da interferência da L1, a Língua Brasileira de Sinais, no desenvolvimento linguístico. Para tanto, analisamos dados da interlíngua de surdos de uma escola que adota a instrução bilíngue (português (escrito) e LIBRAS), adotando uma perspectiva transversal, com os participantes surdos divididos em dois grupos: o grupo $\mathrm{A}, 4^{\circ}$ e $5^{\circ}$ ano, e o grupo $\mathrm{B}$, do $8^{\circ}$ e do $9^{\circ}$ ano. Nossos resultados mostram que a interlíngua dos participantes surdos dos grupos A e B manifesta duas características: (1) a maioria das sentenças ocorre na ordem VO, V, SV, SVO. Esse padrão coincide com a ordem básica de LIBRAS e do português (SVO); (2) não foi observado o uso de pronomes pessoais na posição de sujeito e de objeto nos dados. O desenvolvimento linguístico foi observado em relação aos seguintes aspectos: (1) os participantes do grupo A produzem mais sentenças com argumento nulos e verbos isolados do que os participantes surdos grupo B, o que indica que o estudante do grupo A tem pouco conhecimento das categorias gramaticais do português; 2) os participantes do grupo B apresentam mais sentenças com a posição de sujeito e de objeto preenchida, o que indica que existe domínio maior da estrutura oracional; (3) os participantes do grupo B utilizam um número maior de verbos, o que mostra que a maior exposição ao input linguístico amplia o domínio dos itens lexicais e de seu uso gramatical. Concluímos que o estudante surdo recebe o input linguístico principalmente pela escolarização. Quanto mais avança no nível acadêmico, maior o desenvolvimento linguístico, embora a aquisição das categorias gramaticais seja seletiva, pois segue uma progressão. No entanto, o ideal é desenvolver uma metodologia para que o estudante surdo tenha acesso ao input linguístico de forma estratégica. Considerando os dados da pesquisa, fica evidente que o input linguístico que os estudantes receberam não foi suficiente para desenvolver o conhecimento em relação ao uso dos pronomes pessoais na estrutura oracional, na posição de sujeito e de objeto. É inegável que essa categoria funcional é muito importante para a construção da estrutura oracional.

Palavras-chave: Português como L2, argumentos, L1. 


\begin{abstract}
This study aims to investigate the syntactic expression of the argument structure in tue interlanguage of deafs learners of Portuguese as a second language, in order to verify the acquisition of the grammatical functions. Assuming the hypothesis that the first language (L1), namely the sign language (LIBRAS) has influence in the linguistic development of the second language (L2), we analyse data extracted from the interlanguage collected in a bilingual school for deafs, adopting a transversal perspective, in which the participants are distributed in group A, from the $4^{\text {th }}$ and $5^{\text {th }}$ year, and group B, from the $8^{\text {th }}$ and $9^{\text {th }}$ year. Our results show that the interlanguage of the participants in groups A and B displays two characteristics: (1) the majority of the sentences occur in the order VO, V, SV, SVO. This pattern coincides with the basic order of both LIBRAS and Portuguese (SVO); (2) the use of personnal pronouns was not observed in the subject and in the object position. The linguistic development in turn was observed with respect to the following aspects: (1) the deafs participants of group A produce more sentences with null arguments and bare verbs than the ones of group B, which points to the conclusion that the students of group A have little knowledge of the grammatical categories of Portuguese; 2) the participants of group B have more sentences with the subject and the object position filled, which points to the conclusion that the students of group B have a better performance in mastering clause structure; (3) the participants of group B make use of a bigger amount of verbs than those of group A, showing that more exposure to the linguistic input increases the mastering of the lexical items and of its grammatical properties. We conclude that the deaf student receives the linguistic input of (written) Portuguese mainly through schooling. The more advanced is the academic level more linguistic development is observed, although the acquisition of the grammatical categories is selective, as it follows a progression. Given this, ideally, the methodology should be developed in order to provide the deaf student with the appropriate access to the linguistic input. Considering the results of the present research, it is undeniable that the linguistic input was not robust enough to develop the appropriate use of personal pronouns in the subject and object position of the clause structure, further implying that this functional category plays a crucial role in language development.
\end{abstract}

Keywords: Portuguese as L2, arguments, L1. 


\section{LISTA DE FIGURAS}

Figura 1: A GU é o estágio inicial da aquisição da linguagem

Figura 2: Formas Pronominais usadas com referentes presentes 54

Figura 3: Formas Pronominais usadas com referentes ausentes 54

Figura 4: Formas Pronominais usadas para a $1^{\mathrm{a}}$ pessoa do plural 54

Figura 5: Variações do verbo OLHAR 55

Figura 6: Pronome da $3^{\mathrm{a}}$ pessoa do plural 55

Figura 7: Uso verbo ENTREGAR, TROCAR, BEIJAR 


\section{LISTA DE GRÁFICOS}

Gráfico 1: Características da aquisição de L1 (IDADE) pelos participantes surdos 65

Gráfico 2: Características da aquisição de L2 pelos participantes surdos 66

Gráfico 3: Características do acesso na escola e sua alfabetização pelos participantes surdos 67

Gráfico 4: Características do tipo de surdez pelos participantes surdos 68

Gráfico 5: Caracterísiticas do grau de surdez pelos participantes 68

Gráfico 6: Características dos principais oralista e prótese auditiva pelos participantes surdos $\quad 69$

Gráfico 7: Capacidade de escrever, ler e ver TV com legenda em português (escrito) - auto-
avaliação

Gráfico 8: Características dos pais dos participantes quanto à surdez $\quad 71$

Gráfico 9: Características da família dos participantes quanto a ter parente surdo 71

Gráfico 10: Características da família quanto ao uso de LIBRAS 72 


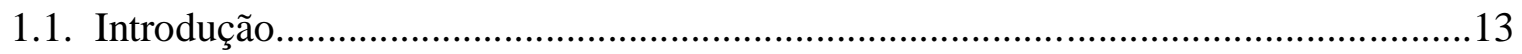

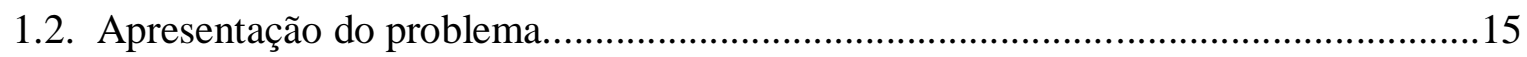

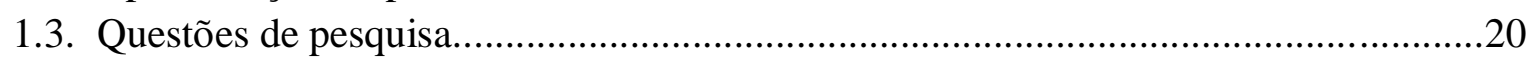

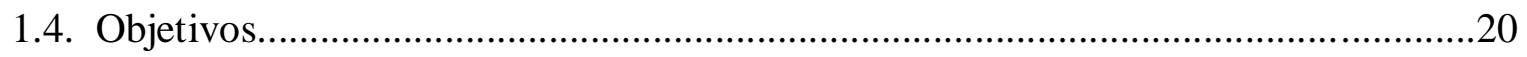

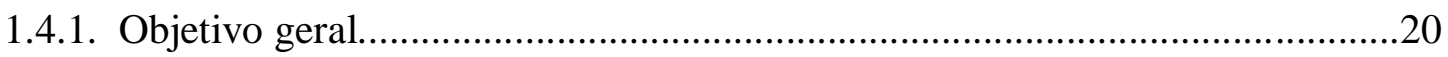

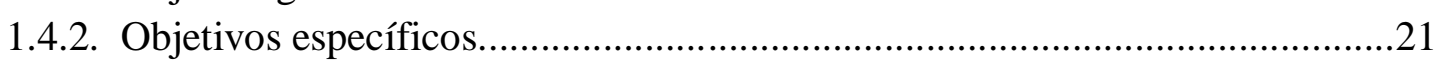

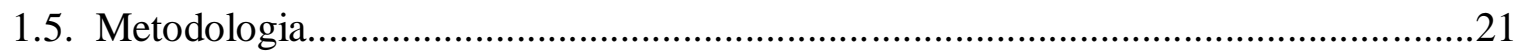

1.6. Referencial teórico.................................................................................................22

1.6.1. Aquisição de L1 e L2 e a teoria de Princípios e parâmetros.............................22

1.6.2. Aquisição de primeira língua (L1) e de segunda língua (L2)..........................25

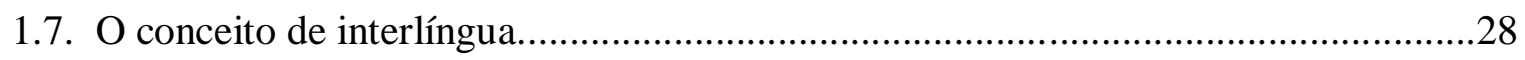

Capítulo II - ESTRUTURA ARGUMENTAL E PAPÉIS TEMÁTICOS....................31

2.1. A arquitetura da linguagem: predicadores e argumentos......................................... 32

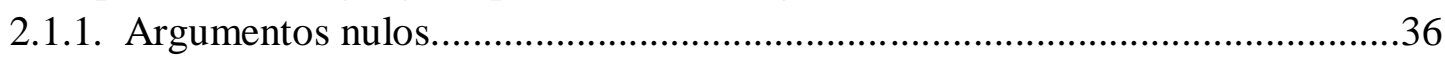

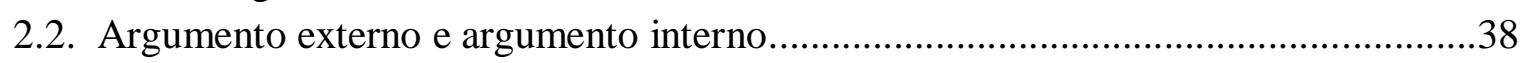

2.3. A estrutura oracional: a posição de sujeito e de complemento...................................40

2.3.1. A árvore sintática da estrutura oracional....................................................41

2.3.2. Papel temático e o seu funcionamento na estrutura oracional..........................42

\section{Capítulo III - ORDEM DOS TERMOS, PRONOMES, CONCORDÂNCIA} VERBAL EM LIBRAS.

3.1. Ordem dos constituintes, tipos de verbos e a realização sintática dos

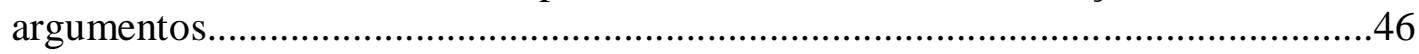

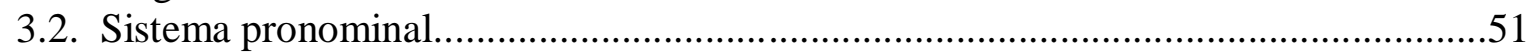

3.2.1. O sistema pronominal no português brasileiro (PB) ......................................51

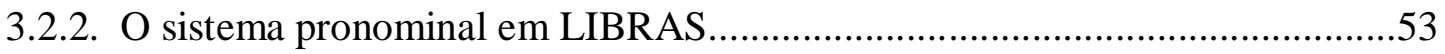

3.3. Verbos sem concordância e verbos com concordância em LIBRAS.............................57

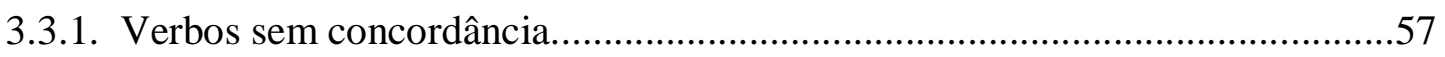

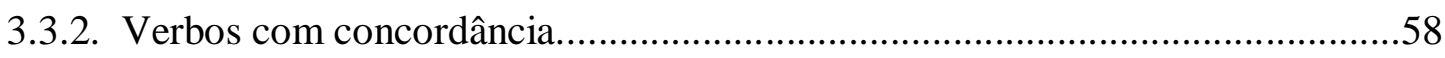

Capítulo IV - ANALISANDO DOS DADOS DA INTERLÍNGUA ….......................61

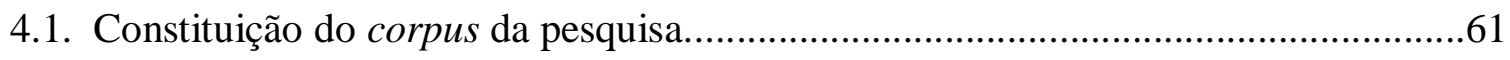

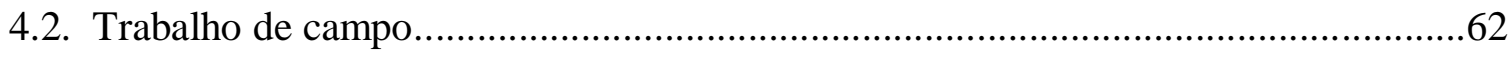

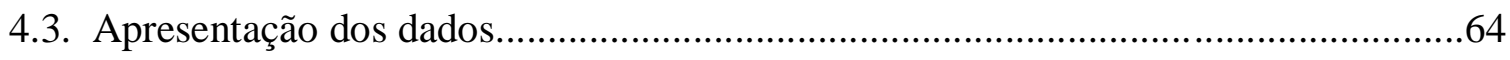

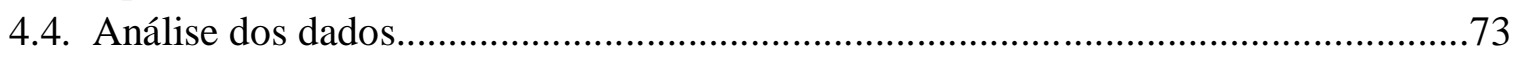


4.4.1. Atividade 1: ordem dos termos e tipo de verbo (VI; VTD; VTDI). . .74

4.4.2. Atividade 2: ordem dos termos e preenchimento da posição de sujeito e de

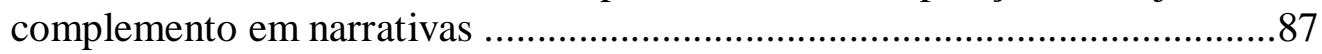

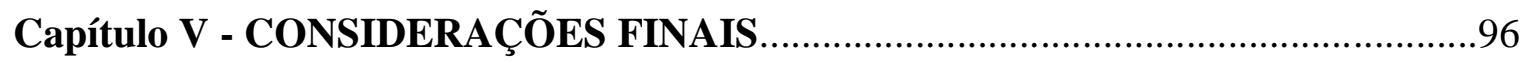

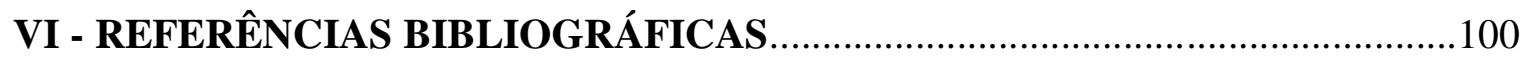

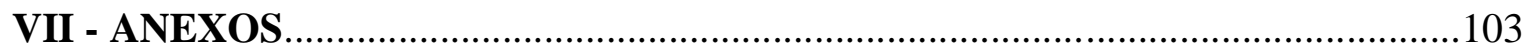

Anexo 1 - Questionários

Anexo 2 - Atividades 1 e 2

Anexo 3 - Comitê de Ética

Anexo 4 - Termos de Autorização e Assentimentos 


\section{INTRODUÇÃO E FUNDAMENTOS DA PESQUISA}

\subsection{Introdução}

Os estudos linguísticos na área de língua de sinais tiveram início a partir de 1960, com o linguista americano Willian Stokoe, que, após buscar os conhecimentos sobre a teoria saussureana, iniciou as pesquisas sobre língua de sinais e confirmou ser esta a língua natural de surdos, ou seja, a primeira língua (L1) dos surdos.

As línguas de sinais são formadas por sinais que têm características como: formas/ configurações da mão, movimento, posição do corpo, e são sistemas linguísticos legítimos e naturais, utilizados pelas comunidades surdas, em que as estruturas linguísticas são veiculadas na modalidade viso-espacial. A partir da concepção de que os sinais nas línguas viso-espaciais correspondem ao que vem sendo chamado item lexical, e que itens lexicais são as palavras de uma língua, como podemos perceber na definição de um conjunto das unidades significativas, concluímos que, nas línguas de sinais, existem também itens lexicais, que recebem o nome de sinais, que transmitem os significados.

Como as línguas naturais existentes, a Língua Brasileira de Sinais, conhecida como LIBRAS e também como LSB ${ }^{1}$, "é composta por níveis linguísticos como: fonologia, morfologia, sintaxe, pragmática e semântica” (Quadros \& Karnopp, 2004).

Sobre a LIBRAS, observa-se a Lei ${ }^{\circ} 10.436$, de 24 de abril de 2002:

[...]Art. 4o O sistema educacional federal e os sistemas educacionais estaduais, municipais e do Distrito Federal devem garantir a inclusão nos cursos de formação de Educação Especial, de Fonoaudiologia e de Magistério, em seus níveis médio e superior, do ensino da Língua Brasileira de Sinais LIBRAS, como parte integrante dos Parâmetros Curriculares Nacionais - PCNs, conforme legislação vigente.

Parágrafo único. A Língua Brasileira de Sinais - LIBRAS não poderá substituir a modalidade escrita da língua portuguesa. (BRASIL, 2002)

\footnotetext{
${ }^{1}$ Preferencialmente é recomendado o uso da sigla LSB devido à convenção internacional que estabelece o uso de apenas três letras para referir-se às línguas de sinais. No entanto, adotaremos neste projeto o rótulo LIBRAS porque é a forma mais conhecida na sociedade brasileira, e também porque é a forma como a legislação se refere à Língua de Sinais Brasileira.
} 
De acordo com lei sancionada acima, a LIBRAS é a primeira língua dos surdos, então a língua oral, língua portuguesa, é a segunda língua, e a escola deve desenvolver apenas na modalidade escrita. Os surdos entram em contato com a escrita para serem alfabetizados em português, portanto a modalidade escrita deve ser desenvolvida na escola. "A língua que o surdo tem como legítima e usa não é a mesma que serve como base ao sistema escrito, por ser um sistema viso-manual, portanto muito diferente do oral-auditivo" (Silva, 2001, p. 48). Nesse caso, vimos que a aprendizagem da escrita corresponde à segunda língua para os surdos.

Consideramos que a opção pelo bilinguismo resulta em uma situação linguística que envolve o uso de duas línguas distintas na comunicação. Assim, a existência de duas línguas no ambiente do surdo e o acesso adequado ao input linguístico torna o surdo bilíngue.

O decreto 5626/2005 estabelece que "a Educação dos Surdos no Brasil deve ser bilíngue, garantindo o acesso à educação por meio da LS (Língua de Sinais) e o ensino da Língua Portuguesa como segunda língua (L2)”. Quadros (1997) pondera que:

\footnotetext{
O bilinguismo é uma proposta de ensino usada por escolas que se propõem a tornar acessível à criança surda duas línguas no contexto escolar. Os estudos têm apontado para essa proposta como sendo mais adequada para o ensino de crianças surdas, tendo em vista que considera a língua de sinais como língua natural e parte desse pressuposto para o ensino da língua escrita. (QUADROS, 1997, p. 27)
}

Este trabalho tem o objetivo de analisar a expressão sintática da estrutura argumental na gramática da língua portuguesa na interlíngua de surdos aprendizes do português L2 e verificar como ocorre a aquisição dessas estruturas, tendo em vista a hipótese da interferência da L1, a Língua Brasileira de Sinais, no desenvolvimento linguístico. Para tanto, vamos analisar a interlíngua de surdos em contexto educacional, na Escola para Surdos de Uberaba-MG, uma escola que adota a instrução bilíngue (português (escrito) e LIBRAS). A gramática da LIBRAS descreve regras que combinam os sinais formando frases que se diferenciam das estruturas linguísticas das línguas orais, como na língua portuguesa (LP), em que a concordância verbal é realizada por meio das conjugações verbais, em que ocorre flexão de modo, tempo, pessoa e número. Pelo fato dos surdos não possuírem acesso às informações orais como 
os ouvintes, esse grupo necessita de um meio escrito ou viso-espacial para receber qualquer tipo de informação.

Salles et al (2004, p. 121) afirmam "que os textos de alunos surdos possuem normalmente enunciados curtos, vocabulário reduzido, ausência de artigos, de preposições, de concordância nominal e verbal, uso reduzido de diferentes tempos verbais, ausência de conectivos (conjunções, pronomes relativos e outros), falta de afixos e verbos de ligação, além de uma suposta colocação aleatória de constituintes na oração". Essas características indicam que existe dificuldade na aquisição de categorias gramaticais da língua-alvo. No presente estudo, a análise da estrutura argumental demonstra que a dificuldade dos aprendizes está situada no preenchimento das funções sintáticas de sujeito e de objeto (direto e indireto) na estrutura oracional, pelo uso de sintagmas nominais e do sistema pronominal. Identificamos também dificuldade na flexão verbal, mas esse aspecto não será considerado em detalhe na análise.

Partimos de um estudo prévio (FERREIRA, 2014), no qual verificamos que existe mais preenchimento da posição de objeto do que da posição de sujeito. Ou seja, as estruturas com sujeito nulo são mais encontradas do que as de objeto nulo. Nossa hipótese de trabalho é a de que tal resultado está relacionado ao fato de que a posição de sujeito pode ser recuperada no discurso, enquanto a posição de objeto é determinada pela estrutura argumental do predicado.

Concluímos que, no processo de ensino-aprendizagem, as crianças surdas têm mais facilidade no aprendizado de português como L2, desde que a metodologia seja adequada para desenvolver o conhecimento da língua como L2. Nesse sentido, é importante também que a criança surda tenha condições de adquirir sua L1 (LIBRAS).

O presente estudo propõe-se fazer a análise da interlíngua, considerando a produção de textos e sentenças em língua portuguesa por surdos matriculados em escola bilíngue que têm a LIBRAS como primeira língua (L1). Para tanto, propomos examinar a realização sintática dos argumentos interno e externo nas sentenças, considerando a interferência da L1 (LIBRAS) na interlíngua.

\subsection{Apresentação do problema}

Sabemos que a escola bilíngue se caracteriza por utilizar duas línguas de instrução, a LIBRAS como L1 e o português escrito como L2. Os surdos adquirem LIBRAS como sua primeira língua, que permite expressar e comunicar suas ideias com 
facilidade. A LIBRAS é uma língua viso-espacial na expressão das relações gramaticais e dos conteúdos semânticos dos enunciados. Quanto à L2, os surdos têm dificuldade de escrever a língua portuguesa, que envolve o uso de propriedades gramaticais distintas em relação a LIBRAS. Nesse caso, questionamos por que a aquisição de L2 ocorre dessa forma: como devemos analisar o fracasso escolar? É responsabilidade da escola ou existe relação da família com o processo de escolarização? São problemas complexos, de natureza social, psicológica, afetiva, que não vamos abordar em detalhe neste projeto. Portanto, vamos investigar as questões linguísticas, considerando aspectos da estrutura gramatical das línguas envolvidas.

A escola bilíngue desenvolve suas atividades educacionais priorizando a LIBRAS e a modalidade escrita da língua portuguesa. Com a observação da produção escrita em português de alunos surdos, verificamos vários fenômenos: sobre a produção de verbos, percebemos que há a ausência de marcação morfológica de tempo, modo, número e pessoa, ou ainda essa flexão não está de acordo com o contexto gramatical. Outros problemas envolvem repetições, ausência de marca de pontuação, de preposições, artigos e outros. Hipoteticamente, os alunos surdos têm acesso à GU (Gramática Universal) e iniciam a aquisição de L1, que é a LIBRAS, e depois devem adquirir a língua portuguesa escrita como L2.

Diante disso, elaboramos este estudo para verificar a forma como as categorias da gramática se desenvolvem na interlíngua do surdo aprendiz de português como L2. $\mathrm{Na}$ análise, discutimos, em particular, a realização da estrutura oracional considerando, o núcleo do predicado e sua relação com sujeito e o complemento. Para tanto, investigamos a interlíngua dos surdos aprendizes do português, para analisar a forma como é realizada a função sintática de sujeito e de complemento na estrutura oracional. Assim, uma questão relevante é investigar que relação pode ser estabelecida entre a flexão verbal e a expressão dos argumentos na posição de sujeito em português. Investigamos também, em uma perspectiva comparada, a realização dos argumentos na posição de complemento.

A interlíngua é o sistema que se manifesta no processo de aquisição de uma segunda língua. Em nossa análise, vamos examinar as sentenças em português e como os alunos surdos realizam os argumentos internos na posição de complemento e os argumentos externos na posição de sujeito. Em nossa análise piloto, e também nos estudos prévios que consultamos, verificamos que, na maioria dos textos criados pelos alunos surdos, os argumentos não estão sintaticamente expressos por meio do sintagma 
nominal, do sintagma pronominal, ou ainda, não existe relação entre o argumento nulo e a presença da flexão no verbo. Hipoteticamente pode ser que os estudantes surdos manifestam essas dificuldades porque a aquisição ocorre em estágios e requer o acesso ao input linguístico adequado. Em relação aos surdos em contexto educacional, pode-se supor que o acesso ao input linguístico foi insuficiente ou faltou o material didático adequado. Outra razão pode ser a falta de conhecimento da L1 (LIBRAS). De acordo com as pesquisas, é desejável que os surdos adquiram sua língua para que possam desenvolver a habilidade de produção escrita de L2 (cf. QUADROS 1997).

A língua de sinais (L1) do surdo utiliza pronomes, verbos, estrutura argumental, e todas as categorias da gramática. Na aquisição da L2, o surdo deverá desenvolver esse conhecimento utilizando as categorias da gramática da língua portuguesa (L2), que está sendo adquirida. O objetivo deste trabalho é analisar a produção escrita em língua portuguesa (LP) como segunda língua (L2) por surdos matriculados da Escola para Surdos "Dulce de Oliveira" na cidade de Uberaba/MG, investigando as características da interlíngua em relação à expressão morfossintática da estrutura argumental de verbos em contexto de oração raiz/ matriz e de oração subordinada.

No corpus examinado, que foram os textos produzidos pelos alunos surdos, constatamos que existe uma realização /omissão dos argumentos dos verbos, na interlíngua dos surdos. Devemos mostrar a tendência para o argumento externo apresentar realização nula, enquanto o argumento interno tem realização lexical. As questões morfossintáticas, como a concordância verbal, o uso de preposições e o sistema de pronominalização serão considerados na análise dos dados.

Para problematizar a questão, tomamos como exemplo dados da interlíngua, de surdos aprendizes de português como segunda língua produzidos em contexto educacional (discutidos em FERREIRA 2014). O texto foi escrito com base em três fotografias, que mostravam um casal, em três momentos da vida: quando crianças, quando adultos, e quando idosos. Os alunos deveriam escrever uma redação para falar de história de amor desse casal. Encontramos o seguinte trecho:

“Conhece criança beija junto amor dela e dele carinha começo futuro também muitos (...)".

Destacamos inicialmente o dado a seguir: 


\section{(1) amor dele e dela}

No caso de amor dela e dela, observamos que o surdo utilizou uma estrutura de posse para expressar a estrutura argumental associada ao verbo 'amar'. A estrutura de posse envolve o substantivo 'amor' e os pronomes 'dele' e 'dela', introduzidos pela preposição 'de', que marca a relação de posse. No entanto, o usuário de L1 não seguiu a gramática do português na elaboração da frase, pois, nesse caso, deveria usar o verbo 'amar'. O verbo amar apresenta dois argumentos um externo e outro interno. Assim, a estrutura argumental do verbo é: amar $(\mathrm{X}, \mathrm{Y})$, e sua realização na estrutura oracional pode ser $\mathrm{X}$ ama $\mathrm{Y}$, em que $\mathrm{X}$ é o argumento externo e $\mathrm{Y}$ é o argumento interno.

$\mathrm{Na}$ interlíngua, para realizar os argumentos X e Y, o surdo utiliza os sintagmas dela e dele. Assim, a estrutura argumental está indicada nos pronomes dele e dela (2 argumentos), mas a estrutura escolhida não está adequada, pois na oração, seria necessário usar o verbo, não o substantivo. No caso do verbo 'amar', seria possível usar duas estruturas: (a) a estrutura transitiva: $X$ ama $Y$ e $Y$ ama $X$, ou (b) a estrutura reflexiva recíproca: $X$ e $Y$ se amam, e os argumentos são realizados como pronome eles, no plural, e nesse configuração satisfazem a estrutura argumental do verbo. O uso da estrutura de posse para realizar a estrutura argumental pode ser explicado pela interferência da L1, pois em LIBRAS, o verbo amar representa a voz reflexiva por meio do sinal PRÓPRIO, e este sinal tem uma realização que pode ser comparada com a realização do pronome possessivo, pois a configuração de mão é a mesma.

Considere os pronomes em LIBRAS, e os dados em que ocorrem na estrutura da oração, a seguir:

(a) O sinal PRÓPRIO,

(b) O possessivo

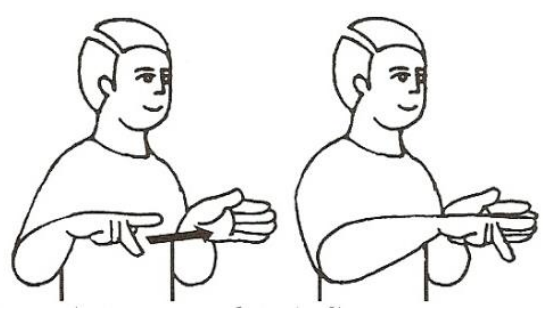

Fonte: Capovilla e Raphael (2001, p.1089).

\section{‘ $<$ ELE-2> $>_{3 p \text { [recíproco] }}$ TER CARRO PRÓPRIO'.}

'Eles têm carro próprio.' 
(3) MEU/MINHA

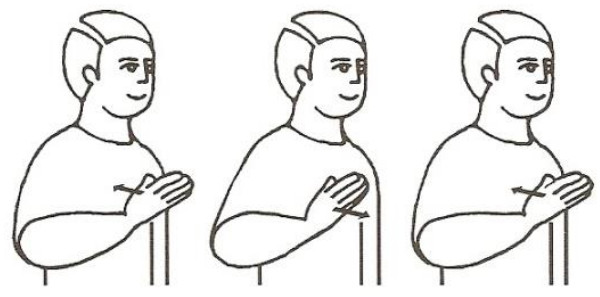

Fonte: Capovilla e Raphael (2001, p.907).

'AQUELA MULHER AMIGA MINHA'.

'Aquela mulher é minha amiga.'

(4) DELES/DELAS
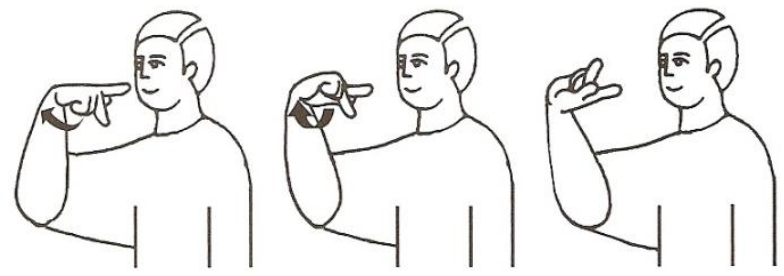

Fonte: Capovilla e Raphael (2001, p.507).

\section{'MESA ESSA CANETA DELA'.}

'Essa caneta na mesa é dela.'

Outro aspecto que se destaca nos dados, é a ausência do argumento externo na oração, conforme ilustrado a seguir:

(5) a. 'conhece criança'

b. 'beija junto'

Nossa hipótese de trabalho é a de que a ausência sistemática do argumento externo é causada por uma interferência de LIBRAS (L1), uma vez que os participantes são definidos no espaço de sinalização, e o surdo os identifica pela apontação. A marcação do referente no espaço de sinalização corresponde, portanto, ao pronome pessoal na posição de sujeito no português. No entanto, o surdo não estabelece uma relação direta entre a marcação do referente no espaço de sinalização em LIBRAS e o uso de pronomes pessoais ou o uso da flexão, em português. Portanto, o input não 
permite verificar que a indicação dos referentes no espaço de sinalização corresponde em português aos pronomes pessoais.

Diante disso, a ausência do pronome na posição de sujeito pode ser analisada como interferência da L1, pois na representação da gramática da LIBRAS e do português, o aprendiz surdo de português não considera a apontação como um tipo de pronome pessoal.

Após essa análise-piloto, vamos investigar os problemas encontrados na realização de argumentos internos e externos nas estruturas de português como L2 observando a realização nos textos que foram produzidos na atividade experimental.

\subsection{Questões de pesquisa}

A partir da análise-piloto, foi feita a constituição de corpus acrescentando mais dados de alunos dessa instituição. Em nosso estudo, buscamos responder as seguintes questões sobre a interlíngua de surdos aprendizes de português como segunda língua, que podem implicar a mudança na realização sintática da estrutura argumental. Nesta afirmação, devemos investigar:

a) Como as categorias pronominais se manifestam na interlíngua?

b) Por que o argumento interno é mais usado do que o argumento externo?

c) Como se manifesta a realização do argumento externo e do argumento interno na interlíngua durante a escolarização?

d) Qual a interferência da L1 (LIBRAS) no desenvolvimento da interlíngua?

\subsection{Objetivos}

\subsubsection{Objetivo geral}

O objetivo deste trabalho é analisar a produção escrita em língua portuguesa (LP) como segunda língua (L2) por surdos matriculados da Escola para Surdos "Dulce de Oliveira" na cidade de Uberaba- MG, investigando as características da interlíngua em relação à expressão morfossintática da estrutura argumental. Para tanto, propomos fazer um estudo transversal, considerando os estudantes em diferentes níveis da escolarização. 


\subsubsection{Objetivos específicos}

Contribuir para os estudos gramaticais do português e da LIBRAS;

Examinar a interlíngua de surdos, observando a expressão morfossintática dos argumentos internos e externos dos verbos nas frases, considerando a interferência da L1 na interlíngua.

\subsection{Metodologia}

Para o desenvolvimento deste trabalho, optamos por uma metodologia de pesquisa exploratória. A instituição onde será realizada a coleta de dados é uma Escola para Surdos em Uberaba/MG, que desenvolve as atividades educacionais buscando priorizar a Língua Brasileira de Sinais e a modalidade escrita da língua portuguesa, adotando-se uma proposta pedagógica em educação bilíngue.

Em nossos procedimentos metodológicos, consideramos que os surdos matriculados na Educação Básica utilizam a língua portuguesa (LP) na modalidade escrita como segunda língua (L2), e adotamos a hipótese de que existe interferência da primeira língua (L1 - LIBRAS) no processo de aquisição da L2. Portanto, a interlíngua na modalidade escrita será diferente de produção escrita de um falante da LP que tem essa língua como L1.

Esta pesquisa apresenta um teste experimental. A atividade é proposta para a investigação da produção escrita dos participantes, que são falantes de LIBRAS como L1, e refere-se à produção de sentenças escritas em LP (L2). Conforme mencionado, a pesquisa tem como objetivo principal é verificar a realização sintática dos argumentos interno e externo nas sentenças produzidas por surdos em português como segunda língua, considerando a interferência da L1 na interlíngua.

Para a coleta de dados, a pesquisa envolve a análise de produção escrita de alunos matriculados no Ensino Fundamental, na Escola Bilíngue para Surdos na cidade de Uberaba/MG. Sendo assim a coleta de dados se deu por meio das atividades escritas em português a partir de um tema proposto livre e comum, com o apoio de recurso visual (fotografia). Conforme mencionado, a pesquisa tem como objetivo principal é verificar a realização sintática dos argumentos interno e externo nas sentenças produzidas por surdos em português como segunda língua, considerando a interferência da L1 na interlíngua. 
A coleta dos dados buscou: (a) estimular, através de diferentes técnicas e recursos, a criatividade e a capacidade dos alunos surdos de externar seus pensamentos de forma clara e objetiva; (b) utilizar vocabulário trabalhado em aula (verbos, substantivos, adjetivos) em português; (c) criar a produção textual como histórias, frases contextualizadas por meio da pedagogia visual.

A identidade dos participantes surdos não será divulgada na pesquisa, e nomes fictícios serão atribuídos a cada um dos participantes. A pesquisa contará com a participação de 19 alunos surdos de ambos os sexos, na faixa etária de 10 a 20 anos, cursando do $4^{\circ}$ ano ao $9^{\circ}$ ano do ensino fundamental, matriculados em instituição de ensino pública, distribuídos em 2 (dois) grupos: $4^{\circ}$ e $5^{\circ}$ ano e $8^{\circ}$ e $9^{\circ}$ ano. ${ }^{2}$

No desenvolvimento da pesquisa, realizamos as seguintes tarefas: aplicar questionários de pesquisa de campo para a identificação dos sujeitos surdos; elaborar entrevistas com sujeitos surdos em relação entre a escola e a família; eliciar produção sintática pelos sujeitos surdos na escrita portuguesa para fins de análise linguística.

Esses instrumentos de coleta de dados permitiu a verificação da hipótese de que o processo de aquisição da L2 está relacionado ao processo de aquisição da L1, pois adotamos a hipótese de que existe interferência da L1 no desenvolvimento da L2. Essa interferência permite comprovar o modo pelo qual a GU é acionada no processo de aquisição da escrita como L2 pelos sujeitos surdos, concluindo que a L1 é o estado inicial.

Nesse sentido, esta pesquisa discute a hipótese da interferência da L1 na aquisição da L2, por meio do conceito de interlíngua. Após a coleta dos dados, fizemos a análise da produção textual em LP por alunos surdos em diferentes turmas do ensino fundamental matriculados na escola pública.

A aplicação das atividades propostas vai contar com o apoio de professor surdo usuário da LIBRAS e de intérpretes de LIBRAS/LP. A constituição do corpus e a sistematização dos dados extraídos dos textos serão realizadas em etapa posterior, com a aplicação de teste estatístico para avaliar os resultados quantitativos.

\subsection{Referencial Teórico}

\subsubsection{Aquisição de L1 e L2 e a teoria de Princípios e Parâmetros}

\footnotetext{
${ }^{2}$ Os dados do $6^{\circ}$ e $7^{\circ}$ ano não foram incluídos porque o objetivo foi mostrar os resultados em dois níveis da escolarização - o nível básico e o nível avançado. Um estudo mais detalhado com os dados desse nível será feito em pesquisa futura.
} 
Segundo Chomsky (1965), a aquisição da linguagem é diferente de outras formas de aprendizagem. O ser humano teria o que foi chamado de Dispositivo de Aquisição da Linguagem (DAL) inato, que, quando ativado, gera a gramática da língua à qual a criança está exposta a partir de sentenças.

Neste trabalho, adotamos a hipótese inatista de Chomsky (1965) e o modelo teórico de Princípios e Parâmetros, desenvolvido em Chomsky (1986). Nessa abordagem, conhecida como biolinguística, à língua é inata, isto é, ocorre em todo o ser humano, e a aquisição da língua é um processo natural. Esse processo de aquisição de língua se inicia com a Gramática Universal (GU). A partir da Gramática Universal (estado mental inicial), a criança vai construindo a sua L1, pelo contato com o input linguístico da comunidade em que está inserido.

Figura 1 - A GU é o estágio inicial da aquisição da linguagem

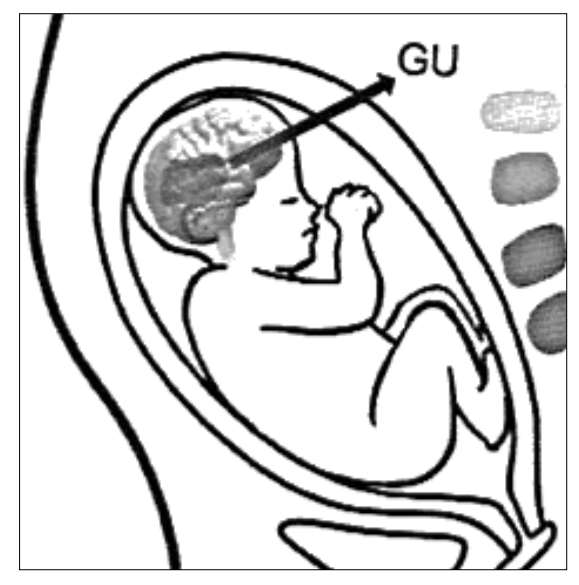

Fonte: Kenedy (2013, p. 95)

A Teoria de Princípios e Parâmetros (TPP) é uma forma de explicar as semelhanças e diferenças entre as línguas e foi originalmente formulada em Chomsky (1986). Os princípios é o comum e universal a todas as línguas. Os princípios se realizam na gramática universal (GU). A GU deve ser compreendida essencialmente como um conjunto de regularidades gramaticais universais. A GU é responsável pelas semelhanças que as línguas compartilham entre si. Serão idênticos em todas as línguas naturais, exatamente porque são previamente especificados pela GU. Um dos princípios da GU estabelece que as frases das diferentes línguas naturais são compostas por sujeitos sintáticos (opostos, na frase, a seus respectivos predicados). 
As diferenças entre as línguas são os parâmetros. Por exemplo, a ordem dos termos na oração:

- SVO em português e LIBRAS:

(6) a. Kiko comprou bombom. (português).

b. ONTEM KIKO COMPRAR BOMBOM (LIBRAS).

- SOV em japonês/turco:

(7) a. Kato okashi kau.

kato doce comprar.

'Kato comprou um doce'

(dado extraído de Mioto et al. 2007, p. 49)

b. Hasan öküz-ü aldo (turco)

Hasan vaca-ACUS comprou.

'O homem comprou uma vaca'.

(dado extraído de Roberts 2007, p. 53)

Segundo o estudo de Kenedy (2013, p. 97), depois de concluído “o processo de aquisição, no estagio estável, os parâmetros de uma língua particular estarão completamente assimilados pela GU e, dessa forma o conhecimento de uma língua especifica, como por exemplo, o português, estará estabelecido na mente da pessoa".

Outro exemplo de contraste entre as línguas é o parâmetro do sujeito nulo. Esse parâmetro se refere ao preenchimento da posição de sujeito na oração. Observamos que é um fenômeno variável, já que, para algumas línguas, o sujeito pode ser nulo, isto é, pode ser omitido numa frase. Muitos dos resultados dos estudos expostos, no item anterior, sinalizam a omissão de argumentos, particularmente, de sujeito pelas crianças. O PB (português brasileiro) e a LIBRAS apresentam características semelhantes quanto ao preenchimento dessa posição sintática por um argumento ou por um pronome (referencial ou expletivo).

Considere os exemplos a seguir, com o valor do parâmetro do sujeito nulo:

Português/LIBRAS: sujeito nulo $\rightarrow$ POSITIVO 
(8) a. Ø Choveu ontem. / ONTEM Ø CHOVER.

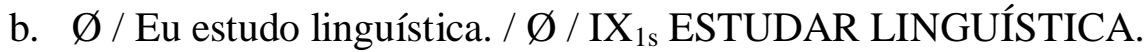

Inglês: sujeito nulo $\rightarrow$ NEGATIVO

(9) a. It / * Ø rained yesterday.

b. $\mathbf{I} * \boldsymbol{\emptyset}$ study linguistics.

A língua de sinais brasileira (LIBRAS) apresenta um outro fenômeno que pode ser tratado como uma manifestação do parâmetro do sujeito nulo e do objeto nulo. É o caso dos verbos de concordância. Um exemplo é o verbo ENTREGAR.

(10) ${ }_{3}$-ENTREGAR -1

A sentença (10) significa "Ele entregou para mim", o verbo realiza um movimento do interlocutor (sujeito) para sinalizante (objeto), portanto, o verbo com concordância indica o sujeito ou objeto da sentença através do espaço, ou seja, através do ponto de partida e do ponto de chegada do movimento do verbo. O sujeito é indicado no ponto de partida e, portanto, não é utilizado o sinal de apontação (IX) na direção do referente de $3^{\text {a }}$ pessoa, mas verbo realiza o movimento a partir do ponto onde está localizada a $3^{\mathrm{a}}$ pessoa, em direção à $1^{\mathrm{a}}$ pessoa, que é o emissor.

\subsubsection{Aquisição de primeira língua (L1) e de segunda língua (L2)}

Segundo Chomsky (1965), a aquisição da linguagem é diferente de outras formas de aprendizagem. O ser humano teria o que foi chamado de Dispositivo de Aquisição da Linguagem (DAL) inato, que, quando ativado, gera a gramática da língua à qual a criança está exposta a partir de sentenças. Essa é a aquisição da primeira língua (L1).

A aquisição de L2 é um pouco diferente da aquisição de L1. Para adquirir a segunda língua, a hipótese que adotamos neste trabalho é a de que a pessoa também se baseia na Gramatica Universal (GU). No entanto, o acesso à GU é feito por meio da primeira língua (L1) (cf. WHITE 2003; LIMA-SALLES \& NAVES 2010). A L1 é o início do processo de aquisição de L2 - em termos cognitivos, é o estado mental inicial. A hipótese de trabalho é que o surdo acessa a LIBRAS para construir a gramática do 
português. Por isso, muitos aprendizes, no processo de aquisição da L2, produzem as frases da L2 usando estruturas da L1.

Partindo da hipótese de que a aquisição de L2 é mediada pela primeira língua (L1), com acesso parcial à Gramática Universal (GU), tem-se a observação de que, apesar da interferência de LIBRAS, a interlíngua não viola os princípios da GU.

Existem trabalhos publicados por estudiosos e linguistas abordando pesquisa com crianças em fase de desenvolvimento, inclusive com crianças surdas. Esses trabalhos demonstram que as crianças surdas podem adquirir a língua de sinais (LS) da mesma forma que as crianças ouvintes, seguindo as mesmas fases do processo.

Quadros (1997) mostra no seu trabalho que o processo de aquisição de línguas de sinais é semelhante ao das línguas orais, mas a pesquisa foi realizada com filhos surdos de pais surdos, e não com filhos surdos de pais ouvintes. Essa diferença é muito importante, pois a aquisição tardia pode apresentar outras características. O ideal é que a criança surda seja exposta à LS precocemente.

Petitto e Marantette (1991) subdividiram o processo de aquisição em quatro estágios: pré-linguístico, estágio de uma palavra/sinal, estágio das primeiras combinações, estágio das múltiplas combinações por tanto o processo de aquisição é universal.

$\rightarrow$ Pré-linguístico: na faixa de 0 a 14 meses de idade - os bebês surdos começam a balbuciar através das mãos, ou seja, é o balbucio manual. Sabemos que de acordo com pesquisas que o input oral não é acessível para essas crianças surdas.

Estágio de uma palavra ou sinal: 12 meses até 2 anos de idade - as crianças surdas iniciam a produzir os sinais como a criança ouvinte pronuncia as primeiras palavras.

$\rightarrow$ Estágio das primeiras combinações: a partir de 2 anos - de acordo com Quadros (1997), a ordem das palavras mais utilizadas pelas crianças surdas é SVO, ou seja, Sujeito-Verbo-Objeto. As crianças surdas utilizam o sistema pronominal (EU e TU) através da indicação/ apontação, de si mesmas e do outro.

$\rightarrow$ Estágio de múltiplas combinações: a partir de 2 anos e meio - crianças surdas adquirirem mais sinais. E ainda existem erros na gramática da sua própria língua, como flexão verbal. 
Ferreira (2013) aborda a importância da aquisição precoce da língua de sinais pela criança surda através do contato visual com seus familiares que sabe língua de sinais, sendo essa atitude fundamental para que as crianças surdas tenham a mesma possibilidade de desenvolvimento linguístico e cognitivo que uma criança ouvinte. Desse modo, a aquisição da língua de sinais como primeira língua gera mais facilidade no aprendizado da língua portuguesa como segunda língua. Essa conclusão está presente em muitos outros estudos, conforme Quadros (1997).

Nesse caso, segundo a autora, o input é o da modalidade viso-espacial, o que confirma que input de língua de sinais é mais adequado para o desenvolvimento da competência linguística da criança surda. Já a aquisição de língua portuguesa, "deve ser em um contexto formal, por meio de exercícios de oralização ou por meio da escrita" (Ferreira, 2013). Dessa forma, a aquisição da L1 gera mais facilidade no aprendizado da segunda língua.

Ainda quanto à aquisição de L2, equivale para surdos a adquirir o português por escrito como segunda língua, por não adquirirem língua de modalidade oral-auditiva. Nesse caso, Svartholm (1994, apud Quadros, 1997, p. 83) afirma que "é importante ter em mente o que é especial nos surdos: eles não podem ouvir”, portanto, os surdos, para ter mais facilidade de recepção e transmissão de informações, conhecimentos, devem ser transmitidos por meio de um canal espaço-visual, ou seja, língua de sinais.

Nesse aspecto, Lima-Salles e Naves (2010) afirmam que, na aquisição de língua, "é fundamental que o input linguístico seja acessível à criança". Nesse caso, crianças com ausência de percepção auditiva devem utilizar língua de sinais.

A maioria de surdos são filhos de pais ouvintes e desconhecem a língua de sinais e isto coloca-os a terem mais dificuldade com a relação à aquisição de língua de sinais, já que o input oral não está acessível para surdos. E para filhos surdos de pais surdos, não há problema nenhum com aquisição da primeira língua.

A língua de sinais que os surdos adquirem como primeira língua "não é a mesma que serve como base ao sistema escrito, por ser um sistema viso-manual", disse Silva (2001). Nesse caso, a aprendizagem do português por escrito deve corresponder à apreensão de uma segunda língua.

Segundo Quadros (1997, p.84), “a necessidade formal do ensino da língua portuguesa evidencia que essa língua é, por excelência, uma segunda língua para a pessoa surda". 
Para a criança ouvinte, a coisa mais simples ir adquirindo a língua de seus familiares e até outras línguas se ela tiver oportunidade de conviver com pessoas que usem essas línguas. Mas ensinar e aprender uma língua, oral ou escrita, para que não tem língua nenhuma (como nos raros casos de crianças criadas sem contato com seres humanos ou, como o caso de crianças surdas, sem contato com línguas) é uma tarefa incomensurável e requer metodologia altamente especializada. Mesmo assim os resultados correspondem aos esforços empenhados. A situação é bem diferente, contudo, para a criança surda que já tem uma configuração linguística (em Língua Brasileira de Sinais - Libras, por exemplo). "A tarefa também não é pequena, mas é bem mais viável e ela pode aprender português (português-por-escrito), com metodologia de ensino de segunda língua, em geral”. (Grannier, 2002, pg.49).

Como citado anteriormente, verificamos que o ideal para os surdos é que aprendam primeiramente a língua de sinais e, quando iniciem a vida escolar, aprendam a língua portuguesa por escrito, mas há a interferência da L1 na aquisição da L2.

“[...] embora seja, incontestavelmente, reconhecido que sem uma língua materna não há ensino/aprendizado de uma segunda língua, um dos problemas, na aquisição de segunda língua, são as interferências que a língua materna faz ocorrer na estruturação e uso da segunda língua, isto é, o 'chega pra lá' que a língua materna dá à segunda língua”. (Ferreira-Brito, 2001, p.8)

As inúmeras teorias do processo de aquisição-aprendizagem da L1 e da L2 afirmam que é um processo complexo. Em relação à aquisição de L2, assumimos a hipótese da interferência da L1 na interlíngua. Essa interferência gera um sistema que se desenvolve em direção à língua-alvo, à medida que ocorre o acesso ao input da L2: a interlíngua. Nesse processo, são relevantes algumas questões sintáticas que envolvem a ordem das palavras, a flexão e a concordância, o uso de pronomes, entre outras.

\subsection{O conceito de interlíngua}

Em 1972, o Larry Selinker criou o termo 'interlíngua - IL', que se refere a 'um estágio intermediário de um aluno que pretende adquirir uma segunda língua”, ou seja, "o sistema de transição criado pelo indivíduo ao longo de seu processo de assimilação de uma língua”. Esse termo inclui a interferência da língua materna, já que é importante distinguir como se manifesta na interlíngua durante o processo de aquisição. 
O conceito de interlíngua se refere ao comportamento linguístico sistemático de aprendizes de uma segunda língua. Selinker aborda a interlíngua como uma pergunta: "é uma hipótese da estrutura psicológica que seria diferente da estrutura linguística latente então como explicar alguns aprendizes adultos são mais bem-sucedidos do que outros e em torno de 5\% são capazes de atingir a proficiência e o desempenho de um falante nativo?’. Essa questão é legítima, mas sua resposta não é fácil, pois envolve a discussão de outros aspectos como o 'período crítico' e 'fossilização'. O primeiro se refere à idade ideal para a aquisição de língua, geralmente até a puberdade, tornando a aquisição de L2 por adultos um processo comprometido. $\mathrm{O}$ segundo diz respeito à tendência observada no aprendiz de L2 de estacionar o processo de aquisição, o que se explicaria pela possibilidade de manter a comunicação com o conhecimento disponível. Segundo Lima (2011) descreve:

\footnotetext{
"Aprendizes de línguas não nativas, no sentido de que o aprendiz pode estabelecer relações próprias a partir de padrões sistemáticos da L2 e que não podem ser consideradas como meros reflexos imperfeitos de alguma norma - nesse caso, a norma seria o padrão utilizado por um falante nativo culto."
}

A palavra interlíngua se divide em dois componentes: 'língua' e 'inter'. A palavra 'língua' representa a ideia de um sistema linguístico autônomo e 'inter', um estágio no desenvolvimento linguístico. Nesse caso, apresenta propriedades da L1 do aprendiz e da língua-alvo (L2), mas se difere de ambas (Selinker 1972 apud Ellis, 1994, 1997).

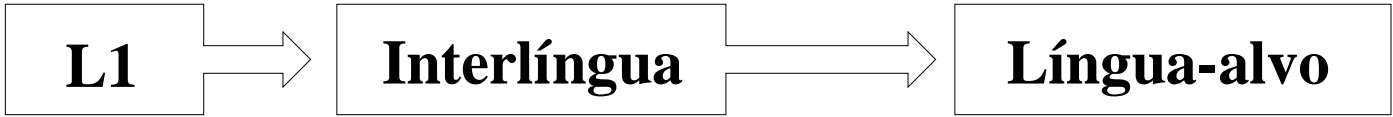

Nemser (1994, p. 84) afirma que "a Interlíngua (IL) enfatiza o fato de que os aprendizes criam sistemas que se aproximam gradualmente da língua-alvo e que variam progressivamente com o nível de domínio dessa língua”.

Adjenian (1992, p. 158) afirma que "a gramática da IL é diferente daquela da língua materna e da língua-alvo, e defende a necessidade de desenvolver uma teoria da Interlíngua." Assim, o autor propõe "uma metodologia que isole os aspectos específicos da IL, distinguindo-a das demais línguas naturais". 
Diante disso, os pesquisadores explicam as estruturas linguísticas durante o processo de aquisição-aprendizagem da L1 e L2, ressaltando que, em ambos os casos, é um processo muito complexo. Portanto, todo aprendiz de L2 tem algumas marcas de uma interlíngua, como estrutura sintática inadequada, construção de sentenças incompletas, falhas na concordância, troca da ordem das palavras na sentença, uso inadequado do verbo e de outros elementos gramaticais.

No processo de aquisição de L2, o surdo, aprendiz de português, desenvolve a interlíngua. Essa interlíngua é muito interessante para o estudo da situação linguística dos surdos. No caso dos surdos (crianças), no início, predominam as características da língua de sinais, que é a primeira língua dos surdos. Com a exposição à L2 (português), nas fases de desenvolvimento, o aprendiz adquire gradualmente as características da L2. 


\section{ESTRUTURA ARGUMENTAL E PAPEIS TEMÁTICOS}

Neste capítulo, tratamos do conceito da estrutura argumental, no que diz respeito aos elementos sintáticos e semânticos e a sua realização na estrutura oracional. $O$ objetivo é sistematizar as propriedades da grade argumental dos verbos e verificar como essas propriedades se manifestam em LIBRAS e em português. Com esse estudo, pretendemos explicar a interferência da LIBRAS no português L2 (escrito) produzidos por surdos em contexto educacional. Para tanto, examinaremos a produção dos participantes de nosso projeto de pesquisa.

Nosso objetivo é demonstrar como se manifesta a estrutura argumental, considerando a relação de um verbo com seus argumentos. Por exemplo, podemos afirmar que o verbo vender tem dois ou três argumentos associados às posições de sujeito e complementos, pois é possível realizar ou não o argumento interpretado como alvo: João vendeu o carro (para Pedro). Portanto, a estrutura argumental pode ser satisfeita em diferentes estruturas oracionais. Diante disso, é preciso considerar que a função semântica é determinada pela quantidade de argumentos.

De acordo com a teoria da estrutura argumental, os argumentos podem assumir vários papéis semânticos (temáticos). Esses papéis semânticos demonstram o envolvimento do participante no evento descrito pelo verbo; assim, um argumento pode funcionar nessa descrição como Agente, Beneficiário, Tema, Alvo, Paciente, Experienciador, entre outros papeis. No entanto, tais funções semânticas podem ocorrer em diferentes posições sintáticas. Por exemplo, o verbo avisar em português admite duas estruturas oracionais: João avisou o horário da prova para o Pedro, e o João avisou o Pedro sobre o horário da prova. Observamos que o argumento interpretado como alvo pode ser realizado na posição de objeto indireto e na posição de objeto direto. Da mesma forma, o argumento interpretado como tema pode ser realizado na posição de objeto direto e na posição de objeto indireto. Em LIBRAS, existe uma restrição independente porque o sinal do verbo AVISAR inclui obrigatoriamente o argumento interpretado como alvo - essa questão será retomada.

A teoria procura estabelecer inventários de papéis temáticos, considerando sua relação com as categorias lexicais, que selecionam argumentos - o que não ocorre com categorias gramaticais, que não selecionam argumentos. Esta seção se propõe investigar 
os verbos como itens lexicais, analisando os seus argumentos do ponto de vista sintático e semântico.

Os dados da pesquisa serão coletados da produção escrita do participante. Vamos propor um conjunto de atividades que envolvem o significado do verbo e a realização dos argumentos na estrutura oracional.

\subsection{A arquitetura da linguagem: predicadores e argumentos}

Conforme mencionamos no Capítulo 1, nesta pesquisa adotamos a hipótese de que as propriedades das línguas naturais são determinadas por princípios da Gramática Universal. Chomsky (1995) afirma que a teoria de Princípios e Parâmetros compreende a GU, mostrando um conjunto de regularidades gramaticais universais, que são os Princípios, e um conjunto limitado de variações linguísticas possíveis, os Parâmetros. Os Princípios servem para todas as línguas. Assim, um princípio de todas gramáticas é possuir itens lexicais e funcionais. A realização sintática dos itens lexicais pode ter ou não argumentos. Os itens funcionais não selecionam argumentos. Os parâmetros, em particular, precisam ser ativados pela experiência do individuo, no contato com a língua de uma comunidade.

Conforme propõe Chomsky (1995), e seguindo a sistematização formulada em Kenedy (2013), os itens lexicais e funcionais possuem traços formais que são acessados pelo sistema computacional. O sistema computacional é responsável por definir a estrutura da oração, que é enviada para a forma lógica (FL) e para a forma fonética (FF). A forma lógica fornece instruções para a interpretação do significado da sentença, enquanto a forma fonética fornece instruções para as estruturas perceptuais, que interpretam a informação sonora (no caso das línguas orais) e visual (no caso das línguas de sinais).

O sistema computacional realiza operações combinatórias sobre os itens do léxico, de maneira recursiva. A formação da sentença inicia com a Numeração, que é o conjunto de itens do léxico que formam essa sentença. A primeira operação do sistema computacional é Selecionar, que retira da Numeração um item do léxico e o combina com outro item do léxico. Esta operação é também chamada de Merge. "Merge é, portanto, a operação computacional criadora de objetos sintáticos complexos (como sintagmas, orações e frases)" (cf. Kenedy 2013: 130). 
A operação Merge é baseada na relação de seleção, que pode ser de dois tipos: seleção de constituinte (seleção-c) e seleção semântica (seleção-s), conforme exemplificamos a seguir:

\author{
Numeração $=\{\ldots$...oão, amar, Maria $\}$ \\ Sistema Computacional $\rightarrow$ Selecionar $\rightarrow$ Merge [amar [Maria]]
}

Conforme observa Kenedy (2013: 131), a operação Merge gera um objeto complexo, que poderá entrar em outra operação com um novo item da numeração, conforme exemplificamos a seguir:

\title{
$\rightarrow$ Merge [João [amar [Maria]]]
}

É interessante notar que, neste nível, as operações de Merge são determinadas pela estrutura argumental do verbo 'amar'. Ou seja, o primeiro Merge indica a relação entre o verbo 'encontrar' e o seu argumento interno 'Maria', que é o tema, e o segundo Merge indica a relação entre o objeto sintático complexo, formado pelo verbo e pelo argumento interno, e o argumento externo, João, que é o experienciador.

Para formar uma oração, é necessário repetir a operação Merge, para concatenar as categorias funcionais que formam a estrutura oracional: $T P$ e $C P$.

\section{[ср C [тр T [sv João [ama [Maria]]]]]}

Mediante essas categorias, será possível identificar se a oração está na voz ativa (João ama Maria), na voz passiva (Maria é amada por João), ou na voz reflexiva recíproca (João e Maria se amam), entre outras propriedades que envolvem as posições sintáticas geradas por essas categorias. Essas operações são determinadas pelos traços formais dos itens do léxico que ocorrem na oração.

Conforme observa Kenedy (2013: 135), o léxico é "o conjunto das informações sobre morfemas, palavras e expressões que se encontram estocadas na mente humana e são acessadas pelo Sistema Computacional durante a derivação de representações linguísticas." O léxico compreende os itens lexicais, que descrevem a realidade objetiva ou subjetiva descrita pelos falantes, e os itens funcionais, que introduzem informações 
gramaticais. Verbos, Substantivos e Adjetivos são categorias lexicais, enquanto Pronomes e Conjunções são exemplos de categorias gramaticais.

Por hipótese, os itens do léxico são formados por três tipos de traços: traços semânticos, traços fonológicos e traços formais. Conforme Chomsky (1995), e exemplificando com um item do português e de LIBRAS: avião/ AVIÃO, identificamos que esse item possui os traços semânticos [entidade]/[artefato], o traço formal da categoria [Nome], o traço formal de número [singular], os traços fonológicos [vogal central aberta; consoante fricativa lábio-dental sonora...]/ [configuração em ' $\mathrm{Y}$ ' com palma para frente, inclinada para baixo; ponto de articulação em espaço neutro; movimento em diagonalmente para cima e para esquerda...].

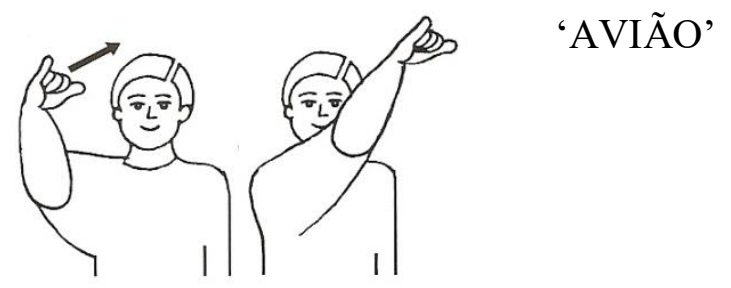

Fonte: Capovilla e Raphael (2001, p.251)

O traço de seleção semântica de um item lexical indica que esse item é um predicador. Um predicador seleciona argumentos. Os traços de seleção específicos do predicador determinam que interpretações semânticas (papéis temáticos) devem ser associadas a cada um dos argumentos de um predicador e a posição que ocupam na estrutura argumental. A estrutura argumental do verbo deve conter a representação do número de constituintes exigidos para a expressão do significado do verbo. Quando os falantes selecionam os itens lexicais comparam cada significado que possuem em sua estrutura semântica.

Como exemplo, para português, o item 'ver', cuja categoria é verbal, V [+V, $\mathrm{N}]$, apresenta dois argumentos. Outro item é 'visão', cuja categoria é nominal N [-V, $+\mathrm{N}$ ]. Essa categoria mostra outro exemplo de um predicador. Então o item 'visão' possui um argumento, pois como é um nome derivado do verbo 'ver', mostra o significado de "ver alguma coisa', Vejamos a sentença "A visão de sua casa pronta emocionou o João". Compare com: "João viu sua casa e se emocionou.". Nas duas sentenças o predicador 'ver' e 'visão' selecionam o mesmo argumento interno 'sua

\footnotetext{
${ }^{3}$ A profa. Déborah Oliveira observou que é possível introduzir o argumento externo, como em: a visão da casa pelo João. A observação é válida também. No entanto, a análise de Kenedy tem por objetivo destacar o argumento interno no significado do verbo.
} 
casa'. Nas duas variantes, os traços lexicais de seleção possuem valores semânticos semelhantes, pois o nome 'visão' é derivado do verbo 'ver'.

Mostramos abaixo a tabela da estrutura argumental desses dois itens, conforme indicado por Kenedy (2013: 145):

\begin{tabular}{|c|l|}
\hline Item lexical & \multicolumn{1}{|c|}{ Traços formais } \\
\hline ver & $\begin{array}{l}\text { Categoria: } \mathrm{V} \\
+ \text { predicador } \\
\text { Estrutura argumental: }[\ldots, \ldots]\end{array}$ \\
\hline visão & $\left.\begin{array}{l}\text { Categoria: } \mathrm{N} \\
+ \text { predicador } \\
\text { Estrutura argumental: }[\end{array}\right]$ \\
\hline
\end{tabular}

Uma diferença entre o verbo 'ver' e o nome 'visão', derivado do verbo, é que o nome pode ocorrer como predicador ou não. "Isso é o que acontece em frases como $E u$ não tenho problema de visão (...)." (Kenedy 2013: 145). Nessa oração, o nome 'visão', não seleciona argumento interno. Concluímos que os verbos podem ser predicadores, e também as categorias nominais, como o Nome e o Adjetivo. Assim, no exemplo apresentado por Kenedy (2013: 146), “Os políticos brasileiros estão conscientes de suas responsabilidades", o predicador 'consciente' seleciona o argumento 'alguém' que tem (ou não) consciência 'de algo'.

Finalmente, Kenedy (2013: 146) mostra que, na frase "A Baía de Guanabara está entre Niterói e o Rio de Janeiro", a preposição 'entre' é um item lexical que seleciona três argumentos: [A Baía de Guanabara], [Niteroi] e [Rio de Janeiro], "sendo, portanto, um predicador com três argumentos" (p. 147). O verbo 'estar' não é um predicador lexical, pois comporta-se como um verbo auxiliar, que tem por função apenas carregar as flexões exigidas pela estrutura oracional, que permitem estabelecer a concordância com o sujeito, e determinar as informações de tempo e modo. A conclusão é que o léxico traz a informação sobre o número dos argumentos de um predicador.

Para verbos de ligação na estrutura do predicado, podemos mostrar os exemplos:

a- O senhor está com frio.

Item/ Verbo funcional: estar

Predicador: Preposição + SN [sP com [frio]] (predicativo do sujeito) 
b- O João está ansioso.

Item/Verbo funcional: estar

Predicador: Adjetivo [sa ansioso] (predicativo do sujeito)

Nesta seção, elaboramos a distinção entre predicadores e argumentos, que é essencial para refletir sobre a estrutura argumental. Conforme mencionamos no Capítulo 1, a hipótese desta pesquisa é a de que a estrutura argumental, ou seja, os argumentos internos e externos são representados na interlíngua. No entanto, existem diferenças entre o português e a LIBRAS na realização sintática desses argumentos. Em particular, a principal diferença é que esses argumentos podem ser nulos no português, particularmente na posição de sujeito. Em LIBRAS, os argumentos nulos ocorrem com verbos com concordância, na posição de sujeito e na posição de complemento.

\subsubsection{Argumentos nulos}

Um aspecto importante da teoria da estrutura argumental é que o número de argumentos de um predicador é fixo e previsível. Assim, no diálogo: “A: - Maria, você viu o João?” / B: - Vi.”, citado por Kenedy (2013: 148), na fala do locutor A, a oração tem o argumento externo 'você' e o argumento interno 'João', mas a fala do locutor B, o argumento externo está expresso na flexão do verbo, e corresponde à $1^{\text {a }}$ pessoa 'eu vi' . O argumento interno não aparece na flexão verbal, mas está previsto na estrutura argumental do predicado 'ver', pois sabemos que a intepretação da resposta do falante B é: [eu] vi [o João].

Assim, numa sentença se o argumento de um predicador não está presente em uma oração isso significa que eles podem ser argumentos sem substância fonética e são representados na teoria como uma categoria vazia.

\footnotetext{
"Trata-se de uma categoria puramente sintática e/ou semântica a serviço da estruturação da frase. (...) Afinal, se tal argumento não estivesse presente na construção, teríamos a violação das propriedades de seleção do verbo e a consequente agramaticalidade da sentença. Como isso não ocorre, devemos, portanto, assumir que a estrutura argumental do item foi satisfeita com um pronome nulo também na posição de objeto." (cf. Kenedy 2013: 149).
} 
De acordo com Kenedy (2013), o funcionamento do Sistema Computacional deve acessar os traços de seleção de um predicador. No entanto, a possibilidade de uma categoria vazia na posição de sujeito pode ser observada quando o sujeito não é argumental, conforme mostramos nas seguintes frases:

a. $\operatorname{pro}_{[+r e f]}$ Mataram o deputado.

b. $\operatorname{pro}_{[- \text {ref }]}$ Está trovejando.

c. [Aqui $\left.{ }_{+l o c}\right]$ não pode fumar. argumento externo [+genérico]

d. * pro $_{[-r e f]}$ Comprou uma casa nova.

As sentenças (a) e (b) são gramaticais, pois apresentam os pronomes foneticamente nulos: em (a), o pronome nulo é referencial e em o pronome nulo (b) é não referencial, pois o verbo denota fenômeno da natureza. Na sentença (c), o argumento externo do predicador fumar é interpretado como genérico, e a posição de sujeito é preenchida pelo sintagma adverbial aqui. Na sentença (d), temos o predicador 'comprar', que possui dois argumentos, e a posição de sujeito não é realizada pelo argumento externo, mas está presente o argumento interno uma casa nova na posição de complemento do verbo.

Os dados a seguir apresentam realizações diferentes da estrutura argumental. Em (a), o item lexical em é um predicador que seleciona o argumento locativo Paris e esse sintagma em Paris seleciona o argumento Ana. Em (b), a sentença é gramatical e indica que o predicador ver tem um objeto nulo (implícito) para realizar o argumento interno do verbo ver, que deve ser recuperado no discurso. Em (c), o argumento interno é realizado em uma posição na periferia à esquerda da oração, e a posição de objeto direto é preenchida por uma categoria vazia. Finalmente, a sentença (d) é agramatical, pois o verbo precisar seleciona uma preposição de para introduzir o argumento interno e essa preposição não está presente.
a. Ana ficou em Paris.
b. [O filme] Arthur viu na TV anteontem.
c. Esse livro, o Pedro precisa.
d. *O Pedro precisa esse livro. 
Para Cyrino (1997 apud Rabelo 2010, p.112), “várias hipóteses foram estudadas nesse sentido, tendo o objeto nulo sido considerado, dependendo das propriedades que apresentava em cada língua, uma variável, uma expressão referencial nula ou pro".

\subsection{Argumento externo e argumento interno}

Como nesse trabalho analisamos a expressão sintática dos argumentos externo e interno, é necessário apresentar a definição desses conceitos, para a análise das sentenças criadas pelos surdos. Os predicadores selecionam no máximo três argumentos. No entanto, conforme observa Kenedy (2013: 152), "há somente duas maneiras por meio das quais o Sistema Computacional pode estabelecer pelo sintático entre um predicador e seu(s) argumento(s). São elas: [predicador $\rightarrow$ complemento] e [especificador $\leftarrow$ predicador]." A posição especificador e complemento dos núcleos lexicais são projeções sintáticas onde são inseridos os argumentos. Essas posições indicam que os argumentos se subdividem em dois tipos: externo e interno.

Os argumentos externo e interno são elementos que constituem a estrutura argumental de um predicado. O argumento externo é realizado na posição do especificador e o argumento interno é realizado na posição de complemento do sintagma projetado pelo predicador.

Vejamos o exemplo a seguir:

(11) A família chamou o médico.

O verbo da sentença acima 'chamou' apresenta um argumento externo que é realizado na posição de sujeito ('A família') e um argumento interno ('o médico'), que é realizado na posição de objeto direto ('o médico'). Essa projeção corresponde à estrutura argumental. No entanto, para construir a sentença, é preciso inserir os argumentos na estrutura oracional. Em português, o verbo concorda com o sujeito, portanto, nessa oração o verbo está flexionado na $3^{\mathrm{a}}$ pessoa do singular, e concorda com o núcleo do sintagma nominal 'família', que é marcado na $3^{\text {a }}$ pessoa do singular.

$\mathrm{Na}$ oração 'A família chamou o médico', o argumento externo e o argumento interno são obrigatórios: se a oração ocorre sem o sujeito ou sem complemento, o ouvinte/leitor não saberá quem chamou 'o médico' ou quem 'a família' chamou, portanto o verbo necessita do sujeito e do complemento para que a sentença seja bem 
formada. Nesse caso, temos dois sintagmas nominais que funcionam como argumentos de um núcleo lexical 'chamar', mas é necessário decidir qual é argumento externo (AE) e qual argumento interno (AI). Se um verbo tem dois argumentos, um é o externo, e outro é o interno.

Adotando a teoria X-Barra da projeção sintagmática, a estrutura sintática fica projetada como a seguir, em que o argumento interpretado como 'agente' é realizado como argumento externo, e o argumento interpretado como 'tema/paciente' é realizado como argumento interno:

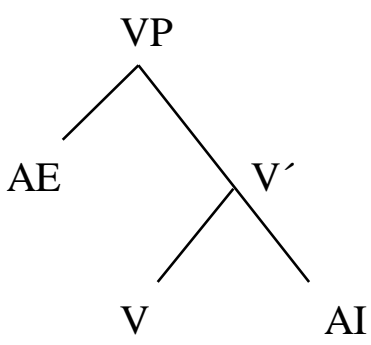

Notamos que $\mathrm{AE}=\operatorname{Spec}($ especificador $)$ e $\mathrm{AI}=\mathrm{Compl}$ (complemento).

Raposo (1992: 275) afirma que "as expressões linguísticas contêm um predicador central e um determinado número de argumentos que lhe completam o sentido, convertendo o predicador numa expressão semanticamente completa”. Já foi mostrado na análise que os argumentos de um predicador verbal correspondem ao sujeito e aos complementos subcategorizados pelo predicador. Vimos como o sintagma verbal comprar é um verbo de dois argumentos, um externo e outro interno.

Passamos a observar outro exemplo: a estrutura argumental do verbo 'pegar' pode selecionar dois argumentos. Vejamos a sentença [X pegar $\mathrm{Y}$ ], sabemos que essa sentença tem dois argumentos que são identificados pelas perguntas: (quem pegou?), então acrescentamos o argumento externo, e (pegou o quêe?), então acrescentamos o argumento interno. $\mathrm{Na}$ estrutura oracional, o argumento externo, que recebe o papel temático de agente, é realizado na posição de sujeito, e o argumento interno, que recebe o papel temático de tema/paciente, é realizado na posição de complemento (objeto direto). Portanto, os predicadores devem ser analisados em função do número de argumentos que selecionam. Mostramos a tabela a seguir, com exemplos de verbos e do número de argumentos que têm: 


\begin{tabular}{|c|c|}
\hline SINTAGMA VERBAL & ESTRUTURA ARGUMENTAL \\
\hline COMPRAR & 2 argumentos \\
\hline GOSTAR & 2 argumentos \\
\hline BRINCAR & 2 argumentos \\
\hline PEGAR & 2 argumentos \\
\hline DAR & 3 argumentos \\
\hline CHEGAR & 1 argumento \\
\hline
\end{tabular}

\subsection{A estrutura oracional: a posição de sujeito e de complemento}

Abordamos nesta seção a estrutura oracional, que inclui a posição de sujeito e de complemento (objeto). De acordo com a teoria gerativa, na oração, o verbo se desloca para a categoria $\mathrm{T}$ (tempo), que é a posição funcional que contém o traço de tempo, e também os traços de pessoa e número, que permitem estabelecer a relação de concordância com o argumento do predicador realizado nessa posição. $\mathrm{O}$ argumento se move da projeção do predicador para a posição de sujeito, que a posição de especificador de ST. Por último, a oração possui o núcleo funcional C, que projeta o SC, e contém as informações sobre o tipo frasal (se a oração é declarativa, interrogativa, exclamativa ou imperativa) e se a oração é absoluta ou subordinada.

O sujeito é selecionado pelo predicador quando expressa seu agente como especificador. O complemento também é selecionado pelo predicador quando a estrutura semanticamente identifica seu tema / objeto. O substantivo que funciona como núcleo do sintagma nominal $(\mathrm{SN})$ será o lexema responsável por controlar a concordância de sujeito da estrutura. Veja o exemplo:

(12) Na festa, Paulo comprou um sorvete para a namorada.

\begin{tabular}{|c|c|c|c|}
\hline Paulo & comprou & um sorvete & para a namorada \\
\hline SUJ & \multicolumn{3}{|c|}{ SV } \\
\cline { 2 - 4 } & V & OD & OI \\
\cline { 2 - 4 } & \multicolumn{3}{|c|}{ COMPL } \\
\hline
\end{tabular}

Prosseguimos acima com análise do predicador 'comprar', que possui três argumentos, 'um sorvete' e 'para a namorada', que são os argumentos internos do predicador e 
realizados como complementos na estrutura oracional, e 'Paulo', que é o argumento externo, realizado na posição de sujeito, que modifica ao predicador. Essas relações estão expressas na projeção da estrutura oracional, conforme será detalhado na próxima seção.

\subsubsection{A árvore sintática da estrutura oracional}

Nesta seção, mostramos a estrutura sintática de uma oração, de acordo com a gramática formal em todas as línguas, de acordo com a GU. Uma árvore sintática produz o modelo de programa que é denominado um analisador sintático. A estrutura começa com a projeção da estrutura argumental do predicador. O verbo se desloca para a categoria $\mathrm{T}$, que é a posição funcional que contém os traços de tempo, pessoa e número. O argumento externo é realizado no especificador de TP. Por último, é projetado o núcleo funcional $\mathrm{C}$, que contém os traços formais que indicam o tipo frasal (se a oração é declarativa, interrogativa, exclamativa ou imperativa) e o estatuto da oração quanto à finitude, que permitem identificar se a oração é absoluta/ principal ou subordinada. Vejamos os exemplos em português e em LIBRAS:

(13) O jacaré comeu o boi.

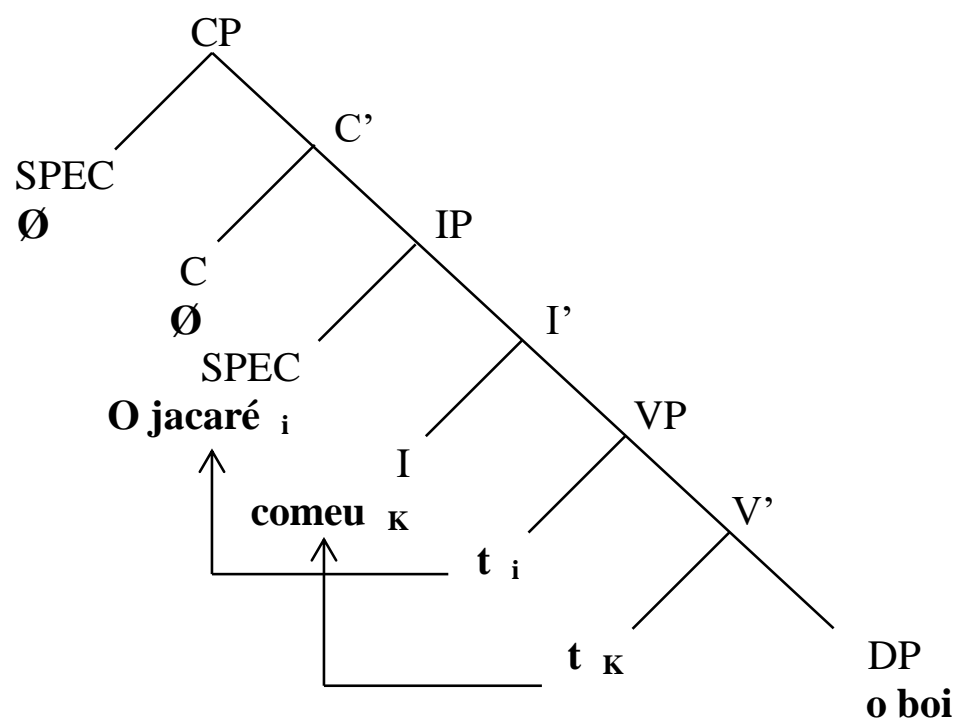




\section{LIBRAS:}

(14) SORVETE ELE GOSTAR. (Ele gosta de sorvete).

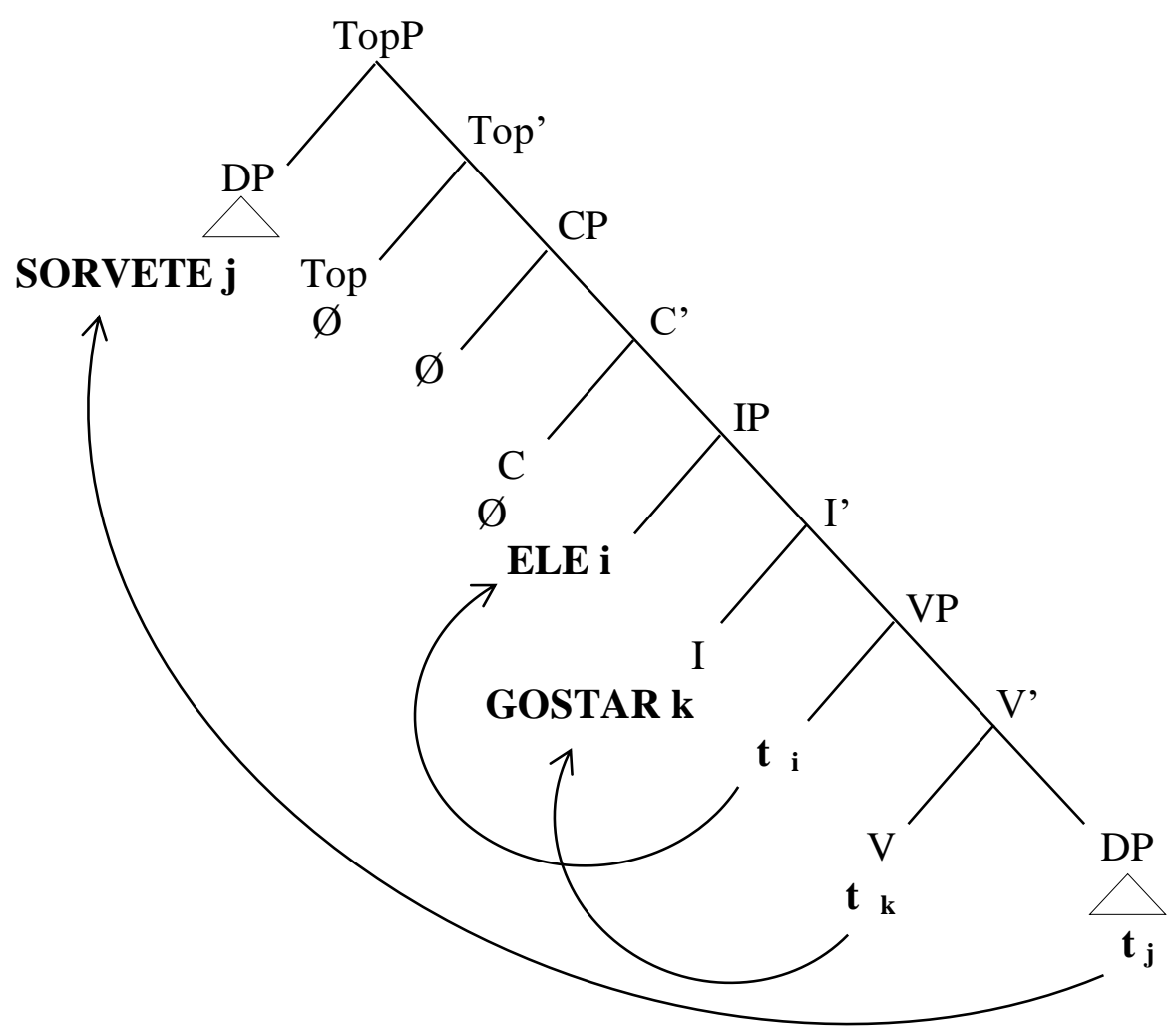

Em (14), o oração apresenta o movimento do DP 'SORVETE' (argumento interno) para a posição de especificador de TopP. Em LIBRAS as estruturas como tópico são muito usadas (cf. QUADROS \& KARNOOP, 2004).

\subsubsection{Papel Temático e o seu funcionamento na estrutura oracional}

Muitos estudos publicados tem mostrado a definição do papel temático. Kenedy (2013) observa que o predicador, além de selecionar argumentos, também determina sua realização como "complementos ou especificadores, e impõe a eles restrições semânticas e categoriais". De modo geral, o papel temático é estabelecido entre um verbo e seus argumentos. Nesse caso, conforme já observamos na seção anterior, existem dois tipos de argumentos: o argumento externo e o(s) argumento(s) interno(s). O exemplo a seguir mostra a relação entre o número de argumentos do predicador, o papel temático e a sua realização na estrutura oracional: 

a) comprar:

\begin{tabular}{|c|c|}
\hline AGENTE & TEMA \\
\hline $\mathbf{i}$ & $\mathbf{j}$ \\
\hline
\end{tabular}

b) realização: [Paula $]^{\mathrm{i}}$ comprou [uma maça. $]^{\mathrm{j}}$

O argumento "Paula" é interpretado como AGENTE, e é projetado como argumento externo. O argumento "uma maçã" é interpretado como TEMA, e é projetado como argumento interno.

As sentenças de uma língua são formadas por uma sequência ordenada de itens lexicais. Os itens lexicais combinados podem formar uma estrutura de constituintes delimitados pela sintaxe a partir de um núcleo. O núcleo seleciona complemento e especificador como mostra o exemplo retirado do trabalho do Mioto et al (2007) a seguir:

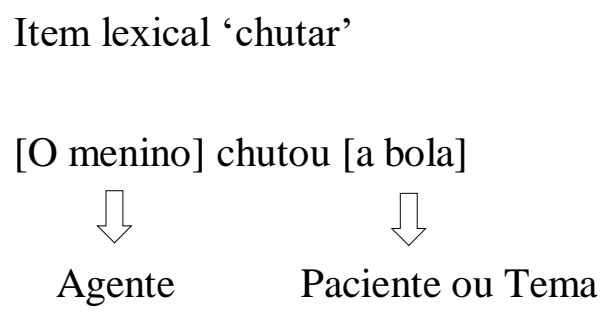

A sentença acima está clara, pois o verbo 'chutou' atribui o papel temático de agente a 'O menino' e de paciente 'a bola'. Nesse caso, há dois argumentos interno e externo. A estrutura argumental do predicado é saturada, possuindo o complemento e o especificador. Nesta sentença, o item lexical 'chutar' necessita inserir dois argumentos para que a sentença seja realizada de forma clara e completa. Além de satisfazer as exigências da estrutura argumental, é preciso satisfazer as demais categorias da estrutura oracional.

Mioto et al (2007, p. 122) afirma que "um dos aspectos mais interessantes das línguas naturais, no que tange à seleção de argumentos, é que os núcleos, especialmente considerando os verbos, têm capacidade muito limitada de selecioná-los". Nesse caso, não são todos verbos que selecionam argumentos, há verbos que expressam fenômenos da natureza que não necessitam de selecionar os argumentos, como os exemplos a seguir: 

(16) a. Choveu.
b. Trovejou.

De acordo com Kenedy (2013: 161), “os papeis temáticos são traços inscritos nas propriedades de seleção de um item lexical predicador. Tais traços são relevantes para a interface conceitual da linguagem humana". Desta forma, as informações relativas ao papel temático de um predicado ou núcleo lexical são necessárias para definir a posição de seus argumentos na estrutura argumental.

Por hipótese, todas as categorias lexicais Nome (N), Verbo (V), Preposição (P), Adjetivo (A) e Advérbio (Adv) têm a capacidade de selecionar argumentos, afirma Raposo (1992). Essas categorias são definidas pelas combinações de dois traços comuns: categoria nominal $[\mathrm{N}]$ e categoria verbal [V]. Esses traços podem ser mostrados com os valores: + ou -, conforme Mioto (2007):

\begin{tabular}{|c|c|}
\hline Nome & {$[+\mathrm{N},-\mathrm{V}]$} \\
\hline Verbo & {$[-\mathrm{N},+\mathrm{V}]$} \\
\hline Adjetivo & {$[+\mathrm{N},+\mathrm{V}]$} \\
\hline Preposição & {$[-\mathrm{N},-\mathrm{V}]$} \\
\hline
\end{tabular}

Estas informações podem ser exemplificadas com o item lexical 'chutar', que se refere ao conjunto de especificações dos papéis temáticos dos seus argumentos. Vejamos como:

\begin{tabular}{|c|l|}
\hline Item lexical & \multicolumn{1}{|c|}{ Estrutura argumental e grade temática } \\
\hline \multirow{4}{*}{ chutar } & Categoria: $[-\mathrm{N},+\mathrm{V}]$ \\
\cline { 2 - 2 } & $\mathrm{N}^{\mathrm{o}}$ de argumentos: $[\ldots, \ldots]$ \\
\cline { 2 - 2 } & c-seleção: $[\mathrm{DP}, \mathrm{DP}]$ \\
\cline { 2 - 2 } & s-seleção: [AGENTE, TEMA/PACIENTE] \\
\hline
\end{tabular}

Além disso, as categoriais funcionais, em relação às lexicais, não possuem capacidade de selecionar argumentos. Essa distinção é importante para representar seu funcionamento no sistema linguístico. São elas: artigos, conjunções, numerais, pronomes e flexões. 


\section{ORDEM DOS TERMOS, PRONOMES, CONCORDÂNCIA VERBAL EM LIBRAS}

Neste capítulo abordamos a diversidade de estruturas das sentenças em LIBRAS, na representação da estrutura argumental. Conforme Felipe (1989) e Ferreira-Brito (1995), a LIBRAS mostra flexibilidade na ordem das palavras na sentença. No entanto, conforme observa Quadros (1999) e Quadros \& Karnopp (2004), existe uma ordem básica na LIBRAS, que é a ordem SVO.

Os estudos mostram que a variação na ordem das palavras tem um papel significativo na análise das línguas. Greenberg (1966) observou que das seis combinações possíveis de sujeito $(\mathrm{S})$, de objeto $(\mathrm{O})$ e de verbo $(\mathrm{V})$, todas são observadas (SVO/VOS/VSO/SOV/OVS/OSV). No entanto, as ordem SVO e SOV são as mais frequentes.

Outro aspecto relevante é a relação de concordância que entre o verbo e o sujeito (S) e entre o verbo e o objeto $(\mathrm{O})$. Essa relação é expressa por afixos flexionais ou por traços de pessoa e número no verbo, que correspondem a propriedades referenciais dos argumentos selecionados pelo predicado. De acordo com Lyons (1987), existem três classes principais de expressões referenciais: nomes próprios, substantivos comuns (núcleo de sintagma nominal) e pronomes. Os pronomes assumem a função de substitutos dos substantivos, mas sua função principal é dêitica. Sabemos que os pronomes são um dos principais indicadores espaços-temporais no contexto do enunciado.

As propostas de alguns autores que pesquisam línguas de sinais (Lillo-Martin \& Klima, 1990; Meier, 1990; Ahlgren,1990; Berenz \& Ferreira-Brito, 1987) chamam a atenção para a questão pronominal e para essa disposição dos espaços. Quando a concordância é gramaticalmente ligada à estrutura da sentença, as marcações de concordância com o sujeito e objeto apresentam uma característica comum entre as línguas. Para a LIBRAS, Quadros \& Karnopp (2004) observam que existe a concordância entre o sujeito e o objeto, dependendo da seleção do verbo. Para abordar essa língua, propõem que existe a classificação dos tipos de verbos em verbos com concordância verbal e verbos sem concordância e apresentam sua relação com a estrutura argumental. 
Vamos analisar essas questões nas seções a seguir.

\subsection{Ordem de Constituintes, tipos de verbos e a realização sintática dos argumentos}

A língua portuguesa (LP), embora seja oral-auditiva, possui estrutura frasal semelhante à estrutura da Língua Brasileira de Sinais, que é viso-espacial, no que se refere à ordem dos termos: SVO. Vejamos a seguir, comparativamente, dados de LIBRAS e do português. Em (1) e (2), temos dados da LIBRAS: ${ }^{4}$

(17) J-O-A-O GOSTAR M-A-R-I-A.

(18) M-A-R-I-A VIAJAR ONTEM SÃO PAULO.

Nas sentenças (17) e (18), os predicados são realizados pelos verbos 'GOSTAR' e 'VIAJAR', que estão sem as marcas de tempo, ou seja, sem flexão verbal de tempo. Mas para indicar o tempo, em alguns casos, por exemplo, os sinalizadores utilizam os itens lexicais como os advérbios 'HOJE', 'ONTEM', 'AMANHÃ', entre outros. O uso dos advérbios de tempo não é obrigatório, se existem indícios contextuais para a determinação do tempo.

Em (19) e (20), a seguir, temos dados do português:

(19) João gosta de Maria.

(20) Maria e João viajaram para São Paulo.

As sentenças (19) e (20) têm as características da estrutura da língua portuguesa. Nessas sentenças, é notória a concordância do verbo 'gostar' e 'viajar' com o sujeito 'João' e 'Maria', respectivamente na $3^{\mathrm{a}}$ pessoa do singular e na $3^{\mathrm{a}}$ pessoa do plural, além da marcação do tempo 'presente' em (19), e do tempo 'passado' em (20). Como visto, a concordância verbal da LP é realizada por meio das conjugações de pessoa, número, de tempo e modo verbais.

Conforme mencionamos anteriormente, a ordem predominante das sentenças em língua portuguesa é: sujeito (S), verbo (V) e objeto (O), normalmente chamada de SVO.

Assim, as sentenças se estruturam da seguinte maneira:

\footnotetext{
${ }^{4}$ A transcrição do item lexical, quando separada por hífen, indica a utilização do alfabeto manual para soletração de nomes que não possuem sinal.
} 
(21) O gato comeu o rato.

$$
\mathrm{S} \quad \mathrm{V} \quad \mathrm{O}
$$

Nessa sentença em LP, a ordem dos constituintes das frases é sujeito, verbo, e objeto. O sujeito da sentença (21) é 'o gato'. Se nesse caso alterasse a ordem dos constituintes e a voz verbal, o sujeito deixaria de ser 'o gato' para ser 'o rato', porém, em língua portuguesa, 'o rato' pode ser o sujeito, mas quem pratica a ação não é sujeito, e sim o agente da passiva. O agente da passiva é um termo integrante da oração. Ele só está presente quando a oração está na voz passiva. Conforme o esquema abaixo:

(21) O gato comeu o rato.

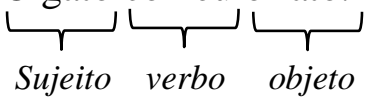

(22) O rato foi comido pelo gato.

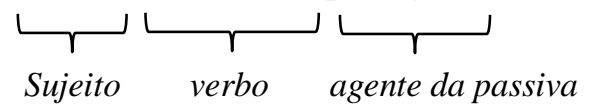

Conforme observado por Lehmann (1978, apud PEZATTI, 1993, p.171), “as línguas SVO requerem a manifestação de seus três constituintes: o sujeito, o verbo e o objeto, o que pressupõe não só o emprego de substitutos de nomes, como os pronomes, mas também os de verbos e orações".

Quadros \& Karnopp (2004) afirmam que a ordem preferencial das sentenças da LIBRAS é SVO. Vejamos os exemplos em relação à ordem:

(23) VOCÊ GOSTAR LASANHA.

$\mathrm{S} \quad \mathrm{V} \quad \mathrm{O}$

(24) MEU AMIGO VIAJAR SÃO PAULO.

$\mathrm{S} \quad \mathrm{V} \quad \mathrm{O}$

Verificamos que as sentenças gramaticais acima (23) e (24) são da ordem SVO, ou seja, sujeito - verbo - objeto. Os estudos das autoras Felipe (1989) e Ferreira-Brito (1995) analisam a ordem das palavras na LIBRAS e evidenciam que a ordem básica da frase é sujeito-verbo-objeto. No entanto, Quadros (1997) investigou as instâncias de categorias vazias argumentais na LIBRAS: 
Tanto a posição de sujeito como de objeto pode ser omitida na LIBRAS observando restrições quanto à classe de verbos e a dependência de elementos do discurso, assim como observa Felipe. Nessas sentenças a ordem SVO é mantida, pois a categoria vazia que "ocupa" as posições de sujeito e objeto apresentam realidade sintática, isso é verificado através da contra parte fonética das posições vazias. (QUADROS, 1997, p.03).

Então, dessa forma, tem-se o exemplo:

(25) ${ }_{\text {b3p }}$ PEGAR a3p

A sentença acima quer dizer ele ou ela (b), que é o sujeito, pegou alguma coisa (a), que é o objeto. Então, não houve o pronunciamento de sujeito e o de objeto que são facilmente recuperáveis mediante contexto da sintaxe na realização do sinal, pois existe um movimento que vai de (b) para (a).

Esse tipo de marcação é observado também no exemplo (26):

(26) a3p ENTREGAR b1p

A sentença (26) significa "Ele entregou para mim", o verbo move-se do interlocutor (sujeito) para sinalizante (objeto), portanto, o verbo com concordância indica o sujeito ou objeto da sentença através do espaço, ou seja, através do ponto de partida e do ponto de chegada do movimento do verbo. Nesse caso, a sentença (25) está na ordem OVS e a sentença (26) está na ordem SVO.

Entretanto outros tipos de ordem são recorrentes: OSV e SOV, que são ordens que podem ser alteradas com a presença do tópico na LIBRAS. Vejamos as ordens:

Nas ordens OSV e SOV, é necessário o uso de marcas não-manuais ${ }^{5}$ de topicalização e de construções com foco. Os exemplos a seguir foram retirados de Quadros \& Karnopp (2004, p.139-141):

SVO:

(27) ELE $_{\mathrm{a} a \mathrm{a}} \mathrm{ASSISTIR}_{\mathrm{b}} \mathrm{TV}$

'Ele assiste TV.'

OSV:

\footnotetext{
${ }^{5}$ Liddel, 1980 e Bahan, 1996 mostram que os sinais manuais são frequentemente acompanhados por expressões faciais que podem ser consideradas gramaticais. Também algumas expressões não-manuais são descritas na língua de sinais brasileira (cf. Quadros, 1999) tais como: marcação de concordância gramatical através da direção dos olhos, marcação associada com foco, marcação da negação, marcação de tópico, marcação de interrogativas (Quadros \& Karnopp, 2004, p. 131-133)
} 
(28) $\mathrm{TV}_{\mathrm{b}}$ ELE $_{\mathrm{a} a \mathrm{aSSISTIR}}$

'Ele assiste TV.'

SOV:

(29) ELE $_{\mathrm{a}} \mathrm{TV}_{\mathrm{b}} \mathrm{ASSISTIR}_{\mathrm{b}}$ 'Ele assiste TV'.

As frases acima são apresentadas em LIBRAS com as marcas não-manuais consideradas como gramaticais. Nesse caso, em LIBRAS, utiliza-se a direção do olhar referindo-se à pessoa.

Quadros \& Karnopp (2004, p. 147) mostram que os dados a seguir indicam casos de ordem OSV, OSV-neg, em oração declarativa, e OSV, em oração interrogativa:

(30) FUTEBOL J-O-A-O GOSTAR

'De futebol, João gosta.'

É sentença com marca não-manual de foco.

(31) FUTEBOL J-O-A-O GOSTAR-NÃO

'De futebol, o João não gosta.'

É sentença gramatical com marca não-manual de negação.

(32) FUTEBOL J-O-A-O GOSTAR?

'De futebol, o João gosta?'

Apresenta como sentença com marca não-manual de interrogação.

Outro exemplo na LIBRAS de construções com foco (Quadros, 1999) é um caso em que foi derivada uma das estruturas SOV, conforme ilustrado em (33). Isso acontece com verbos sem concordância, que apresentam constituintes duplicados. Vejamos o exemplo retirado de Quadros \& Karnopp (2004, p. 153). As autoras assumem a duplicação do verbo 'PERDER' em posição final, e depois o apagamento da primeira ocorrência do verbo no nível da forma fonológica $(\mathrm{FF})$, gerando a ordem SOV:

(33) EU PERDER LIVRO < PERDER >mc

Eu perdi o livro.

As ordens SVO/VOS/SOV podem estar associadas ao foco duplicado e ao foco contrastivo . Vejamos a seguir os exemplos retirados de Lima (2011, p. 57): 


\section{Foco duplicado}

(34) EU PODER IR <PODER >mc [SAuxVAux]

'Eu $P O S S O$ ir [a algum lugar]'

(35) <QUEM GOSTAR GATO>qu <QUEM>qu [SVOS]

'QUEM gosta de gato?'

(36) $\mathrm{EU}<\mathrm{NÃO}$ IR >neg $<\mathrm{NÃO}>$ neg $[\mathrm{SNegVNeg}]$

'Eu $N \tilde{A} O$ vou [a algum lugar]'

\section{Foco contrastivo}

(37) [o que o homem perdeu a chave ou a aliança?]

HOMEM PERDER <ALIANÇA >mc $(<$ CHAVE NÃO>neg) [SVO]

'O homem perdeu A ALIANÇA (não a chave)'

(38) [o que o garçom fez com o cheque: rasgou ou apagou?]

GARÇOM CHEQUE<APAGAR>mc (<RASGAR NÃO>neg) [SOV]

$\mathrm{O}$ garçom $A P A G O U$ o cheque (não rasgou)

(39) [quem comprou a casa: Artur ou Maria?]

COMPRAR CASA $<$ ARTUR $_{a}$ IX $_{a}>$ mc $\left(<\right.$ MARIA $_{b} \quad$ IX $_{b}$ NÃO $>$ neg $)$ [VOS]

$O$ ARTUR comprou a casa (não a Maria)

Apresentamos, a seguir, o quadro que sistematiza as ordens em LIBRAS conforme Quadros \& Karnopp (2004, p. 156):

\begin{tabular}{|c|c|c|}
\hline ORDEM & SIM & $\begin{array}{c}\text { COM } \\
\text { RESTRIÇÕES }\end{array}$ \\
\hline SVO & $\mathrm{X}$ & \\
\hline OSV & & $\mathrm{X}$ \\
\hline SOV & & $\mathrm{X}$ \\
\hline VOS & & $\mathrm{X}$ \\
\hline
\end{tabular}

Distribuição da ordem das sentenças na LIBRAS

Além disso, sabemos que, em LIBRAS, existem preposições/posposições e conjunções, mas ainda percebemos que estes conectivos são usados em poucos contextos sintáticos em LIBRAS. A seguir, mostramos os itens lexicais COM / JUNTO, ATÉ, SOBRE, que são utilizados como preposições na LIBRAS, e conjunções como 
PORQUE, SE, que também fazem parte das categorias funcionais da língua e podem ocorrer em diferentes ordens na estrutura oracional.

Vejamos as sentenças com as preposições/ posposições e as conjunções:

(40) COMER ARROZ FEIJÃO JUNTO SEMPRE EU GOSTAR.

Eu sempre como arroz com feijão porque gosto.

(41) CACHORRO PASSADO IR ATÉ PORTA.

O cachorro foi até a porta.

(42) $<$ MESA $>_{\text {top }}$ LIVRO SOBRE.

O livro está sobre a mesa.

(43) EU GOSTAR DELE PORQUE ELE EDUCADO.

Eu gosto dele porque é muito educado.

(44) $\boldsymbol{S E}$ VOCE $_{2 s} \mathrm{OBEDECER-NÃO}_{1 s}$ VOU BRAVO.

$\boldsymbol{S e}$ você me desobedecer, ficarei muito bravo.

\subsection{Sistema Pronominal}

\subsubsection{O sistema pronominal no português brasileiro (PB)}

No português brasileiro (PB), a Gramática da Língua Portuguesa indica que os pronomes pessoais são palavras que substituem os substantivos e apresentam uma das três pessoas do discurso (cf. CUNHA \& CINTRA, 1985/2010). Os pronomes podem ocorrer no caso reto e no caso oblíquo. Vamos mostrar ambos os casos a seguir:

No português brasileiro, os pronomes pessoais são subdivididos em:

$>$ do caso reto: função de sujeito na oração.

- $1^{\text {a }}$ pessoa (quem fala): $e u$-singular, e nós-plural;

(45) a. $\boldsymbol{E} \boldsymbol{u}$ fui ao cinema de ônibus. (eu $=1^{\text {a }}$ pessoa do discurso/ sujeito)

b. Nós saímos do zoológico. (nós $=1^{\mathrm{a}}$ pessoa do discurso/sujeito) 
- $\quad 2^{\mathrm{a}}$ pessoa (com quem se fala): $t u /$ você-singular e vocês-plural;

(46) a. Comprei o jornal para $\boldsymbol{t} \boldsymbol{u}$ leres! (tu $=2^{\mathrm{a}}$ pessoa do discurso/ sujeito)

b. Vocês gostam de mim? (vocês $=2^{a}$ pessoa do discurso/ sujeito)

- $\quad 3^{a}$ pessoa (de quem se fala): elelela-singular e eles/elas-plural.

(47) a. Ele comeu sanduíche ontem. (ele $=3^{\mathrm{a}}$ pessoa do discurso/ sujeito)

b. Eles passearam na praia. (eles $=3^{\mathrm{a}}$ pessoa do discurso/ sujeito)

do caso oblíquo: função de objeto ou complemento na oração. Os pronomes oblíquos subdividem-se em:

- oblíquos átonos: nunca são precedidos de preposição, são eles:

\begin{tabular}{|c|c|c|}
\hline & Singular & Plural \\
\hline $1^{\mathrm{a}}$ pessoa & me & nos \\
\hline $2^{\mathrm{a}}$ pessoa & $\mathrm{Te}$ & - \\
\hline $3^{\mathrm{a}}$ pessoa & se; o/a; lhe & se; os/as; lhes \\
\hline
\end{tabular}

(48) a. Desculpem-me.$($ me $=$ objeto $)$

b. Nós $\boldsymbol{o}$ ajudamos. (o = complemento)

Os pronomes átonos de $3^{\mathrm{a}}$ pessoa se dividem em: pronomes da função objeto direto (o/a; os/as), pronomes da função objeto indireto (lhe; lhes) e o pronome se, que ocorre com verbos pronominais (reflexivos/ recíprocos), como em Eles se beijaram, e na marcação sintática do sujeito indeterminado, como em Precisa-se de balconista (=Alguém precisa de balconista). $\mathrm{Na} 2^{\mathrm{a}}$ pessoa do plural, não existem pronomes átonos no PB. Para realizar a $2^{\mathrm{a}}$ pessoa do plural é usado o pronome vocês, mas esse pronome não é átono.

- oblíquos tônicos: sempre precedidos de preposição:

\begin{tabular}{|c|c|c|c|}
\hline & Preposição & Singular & Plural \\
\hline $1^{\text {a }}$ pessoa & \multirow{4}{*}{ para/ de/ em } & mim & nós \\
\cline { 1 - 2 } $2^{\text {a }}$ pessoa & ti; você & vocês \\
\cline { 1 - 2 } $3^{\text {a }}$ pessoa & & ele/ ela; si & eles/ elas \\
\hline
\end{tabular}


A preposição de, em, com podem ocorrer contraídas com o pronome, como em: dele/ dela $(=d e+e l e / d e+e l a) ;$ nele/ nela $(\mathrm{em}+\mathrm{ele} / \mathrm{em}+\mathrm{ela}) ;$ comigo/ contigo $\left(=c o m+1^{a}\right.$ pessoal com $+2^{a}$ pessoa).

(49) a. Você comprou esta blusa para mim? (para mim = objeto indireto)

b. Você sabe que eu gosto de $t i$. (de ti = objeto indireto)

c. Amanhã vou ao cinema contigo. (contigo = adjunto adverbial)

\subsubsection{O sistema pronominal em LIBRAS}

De acordo com Ferreira-Brito (1995: 47), “a LIBRAS apresenta três pessoas do discurso, no singular e plural. Em todos os casos do singular, a configuração usada é a mão em [G1]. Na primeira pessoa, o indicador aponta para o peito do locutor; na segunda, para o interlocutor; as terceiras pessoas são representadas por ponto no espaço, estabelecidos durante o discurso, ou pela localização do referente presente. O plural é expresso através do movimento semicircular para a segunda pessoa e do movimento circular para a primeira pessoa".

A autora afirma que a LIBRAS possui pronomes pessoais verdadeiros, ou seja, não são simples formas com loci referenciais associados, nem advérbios locacionais. Para Lillo Martin \& Klima (1990), o sistema pronominal nas línguas de sinais se realiza por meio da apontação que apresenta uso das configurações de mão.

Quadros (1997) afirma que nas línguas de sinais os referentes do discurso são marcados pela indicação de um ponto no espaço de sinalização. Esse espaço é definido na frente do corpo do sinalizador, que pode ser mencionado através de várias maneiras, conforme Quadros \& Karnopp (2004). Na figura 2, os pronomes pessoais de $1^{\mathrm{a}}, 2^{\mathrm{a}}$ e $3^{\mathrm{a}}$ pessoa do discurso apontam com o dedo indicador a quem o sinalizador se refere se estão presentes: apontará no próprio peito, quando for o locutor, e apontará diretamente na direção do interlocutor ou da $3^{\text {a }}$ pessoa. Assim as formas pronominais são usadas com referentes presentes, conforme ilustrado a seguir.

FIGURA 2 - Formas Pronominais usadas com Referentes Presentes 

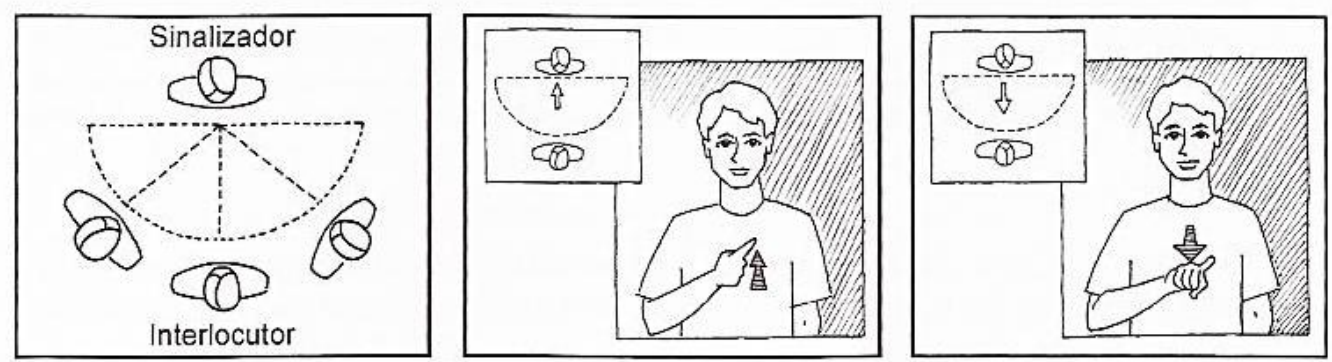

(Quadros, 1997, p. 51 adaptada de Lillo-Martin \& Klima, 1990:192)

Na figura 3 mostramos o uso do pronome (apontação) quando o referente não estiver presente, ou ausente, e pode ser usado para referir a objetos e lugares no espaço. Nesse caso, a direção do olhar movimenta para o lado e para o outro, e marca um ponto estabelecido no espaço. O exemplo de Lillo-Martin \& Klima (1990) mostra no discurso a sinalização com referentes na terceira pessoa, no espaço de apontação. Os autores esclarecem que, quando o ponto é para a direita do sinalizador, se refere a 'João', e para a esquerda do sinalizador, se refere 'Maria', conforme ilustrado na figura:

FIGURA 3 - Formas Pronominais Usadas com Referentes Ausentes
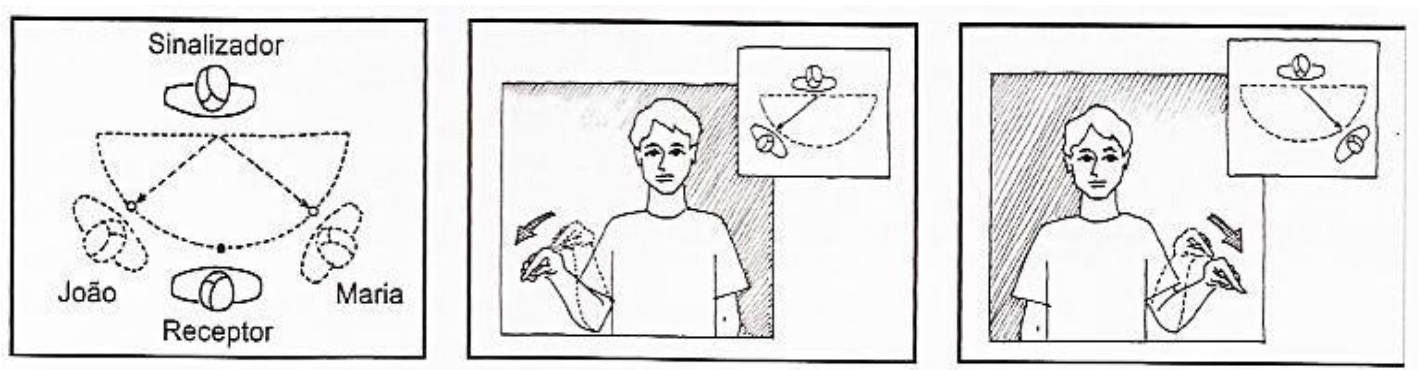

(Quadros, 1997, p. 52 adaptada de Lillo-Martin \& Klima, 1990:193)

A figura 4 tem duas formas que representam referentes presentes e não-presentes no discurso. A apontação do dedo indicador tem a mesma configuração só que a direção muda à forma do pronome NÓS entre duas opções: 〈eu + vocês〉 e <eu + eles〉.

FIGURA 4 - Formas pronominais usadas para a $1^{\text {a }}$ pessoa do plural
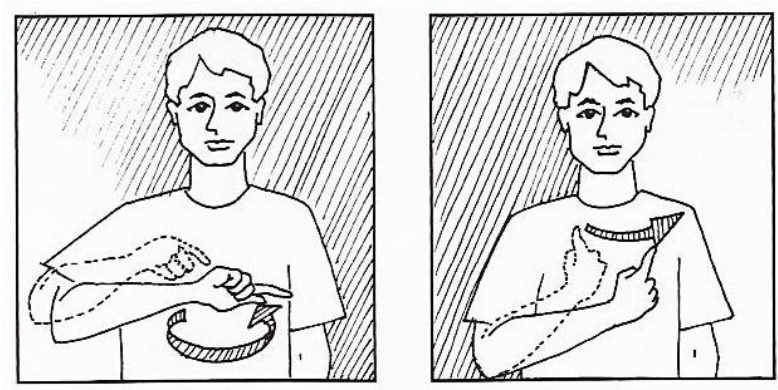


$$
\text { NÓS }=\mathrm{eu}+\text { vocês } \quad \text { NÓS }=\mathrm{eu}+\text { eles }
$$

(Quadros, 1997, p. 55 adaptada de Baker \& Cokely, 1980, p. 209)

Outro aspecto é que existe o uso da direção oposta no espaço em que a apontação se movimenta ao mesmo tempo. Esse caso chama-se de pronome recíproco. Quando os verbos descrevem um evento que afeta duas pessoas ou dois objetos, ao mesmo tempo, a apontação é com duas configurações iguais. Na LIBRAS, o sistema pronominal no plural apresenta a forma ELE-2 para indicar recíproco. As figuras 5 e 6 mostram o uso do pronome recíproco com o verbo OLHAR.

FIGURA 5 - Variações do verbo OLHAR

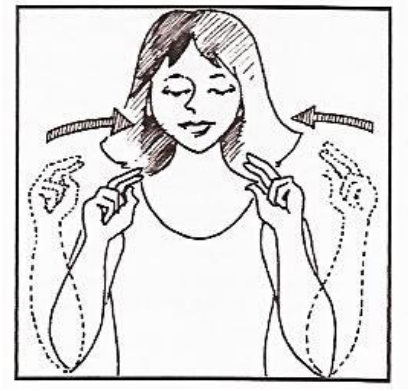

"Eles se olharam"

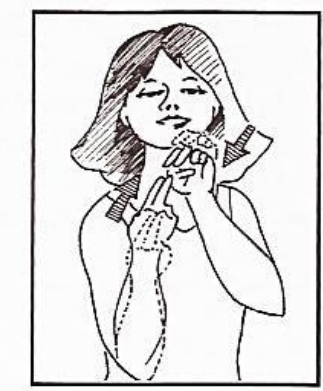

"Nós nos olhamos"

(Quadros, 1997, p. 64 adaptada de Baker \& Cokely, 1980, p. 249-250)

FIGURA 6 - Pronome da $3^{\text {a }}$ terceira pessoa do plural

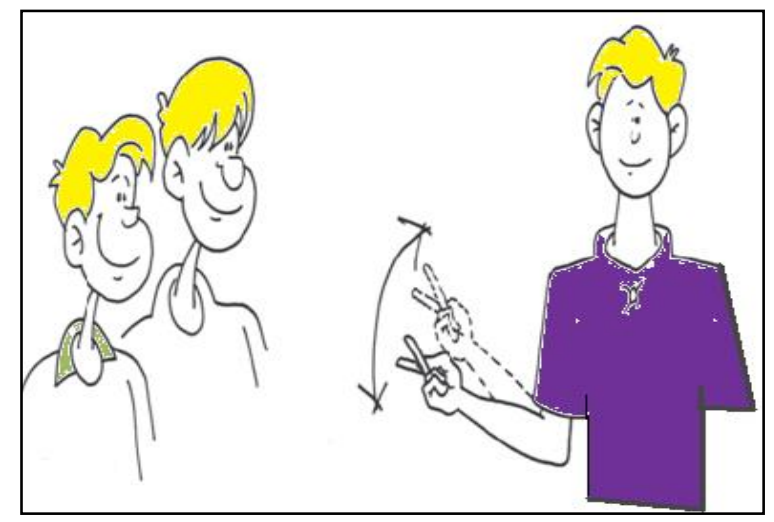

ELE-2 (dual)

Fonte: FELIPE \& MONTEIRO (Libras em Contexto, 2007 p. 84)

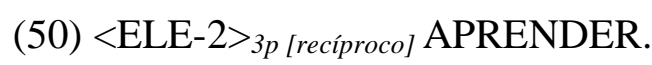

('Eles aprenderam um com o outro'). 
Em LIBRAS, há marcação de reciprocidade pelo uso do verbo com o movimento oposto, conforme mostram os pesquisadores Quadros \& Karnopp, 2004, também encontrados na ASL - American Sign Language (cf. KLIMA \& BELLUGI, 1979). A figura 7 mostra os verbos ENTREGAR, TROCAR, BEIJAR, etc.

FIGURA 7 - Uso verbo ENTREGAR, TROCAR, BEIJAR

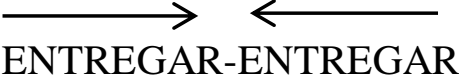

('Eles entregaram [o livro] um para o outro')
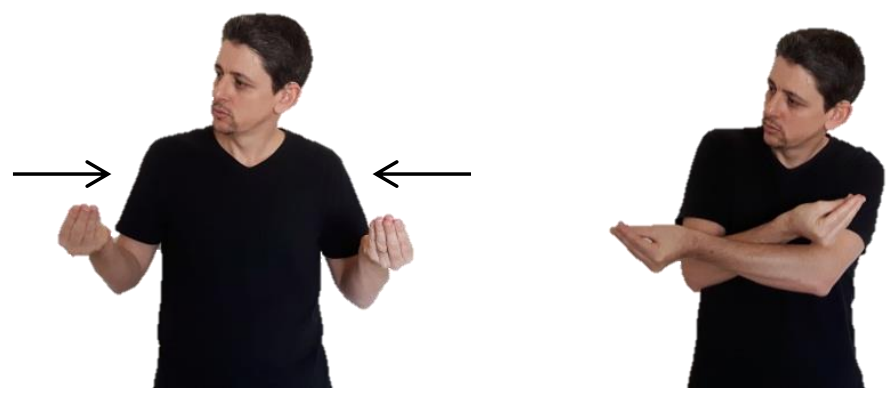

$(52)$

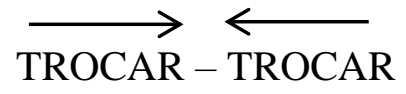

'Eles trocaram [o carro] um com o outro'
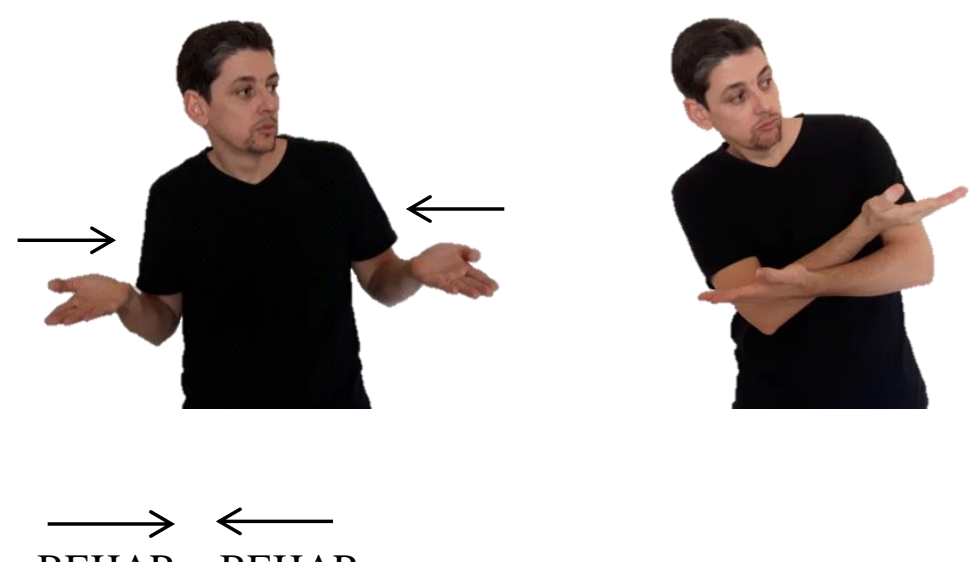

'Eles se beijaram'
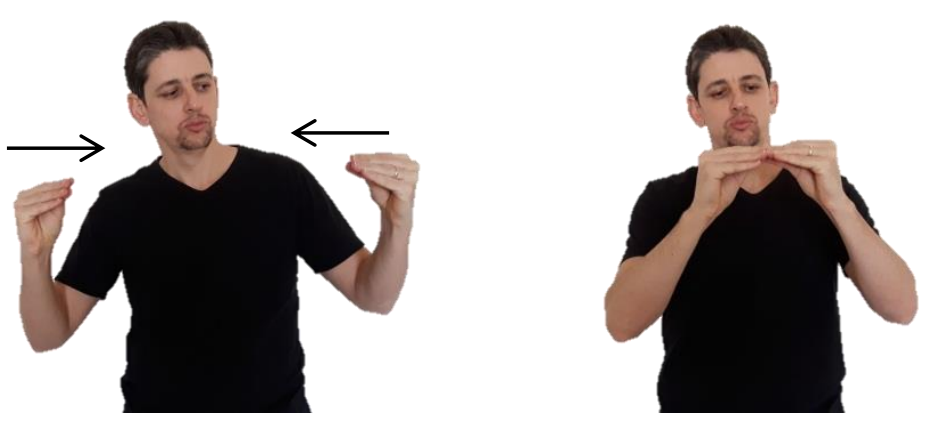
Na análise do sistema de marcação de pessoa, Ferreira-Brito (1995: 48) observa que "os verbos direcionais manifestam as flexões para pessoa e número nos pontos inicial e final do movimento". Com isso, é possível afirmar que a LIBRAS é uma língua de sujeito nulo, em que o referente é marcado no verbo, como uma flexão. Essa análise permite também considerar que a LIBRAS é uma língua de objeto nulo, com o referente marcado no verbo, como uma flexão. Essa questão será tratada, com mais detalhe, na próxima seção.

\subsection{Verbos sem concordância e verbos com concordância em LIBRAS}

Vamos abordar, nesta seção, outro aspecto importante da gramática de LIBRAS, que é a presença de verbos sem concordância e verbos com concordância. Quadros \& Karnopp (2004) propõem a seguinte classificação:

- verbos sem concordância: se subdividem em verbos simples e verbos espaciais;

- e verbos com concordância.

\subsubsection{Verbos sem concordância}

De acordo com autoras, os verbos simples em língua de sinais são aqueles que não marcam o referente na estrutura do sinal. Portanto, podemos dizer que não possuem flexão de pessoa e número e também não possuem afixos locativos como: APRENDER, CONHECER, LEMBRAR, etc.

(a)

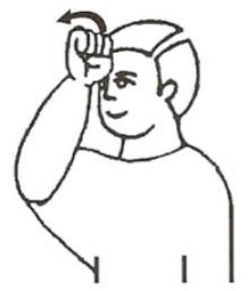

(b)

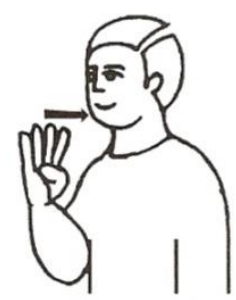

Fonte: Capovilla e Raphael (2001, p.215, 449 e 807) (c)

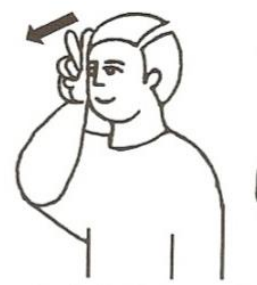

Nos exemplos ilustrados anteriormente, os verbos têm o parâmetro de ponto de articulação dos sinais ancorados no corpo, e não realizam movimento a partir de um referente (sujeito) em direção a um referente (objeto direto), portanto são chamados de verbos simples. A indicação dos referentes (na posição e sujeito e de objeto) é feita pela 
apontação dos interlocutores $\left(1^{\mathrm{a}}\right.$ e $2^{\mathrm{a}}$ pessoa) ou de pontos no espaço de sinalização $\left(3^{\mathrm{a}}\right.$ pessoa).

Ferreira (2013, p. 44) afirma que os verbos espaciais por "denotar movimento e posição no espaço, por essa razão, admitem afixos locativos, que identificam locais no espaço neutro da sinalização", como no caso do verbo CHEGAR e COLOCAR, ilustrados respectivamente, a seguir.

(a)

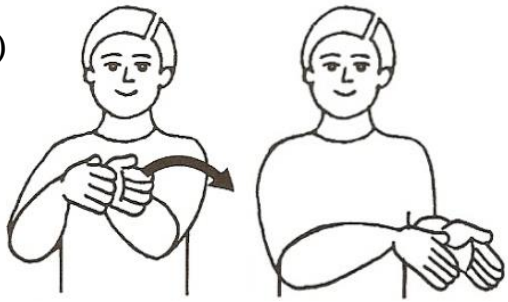

(b)

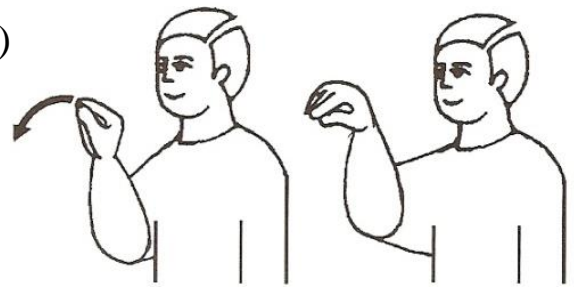

Fonte: Capovilla e Raphael (2001, p. 398 e 430)

\subsubsection{Verbos com concordância}

Os verbos DAR, AVISAR, PERGUNTAR, RESPONDER são exemplos de verbos com concordância em LIBRAS, por indicar em sua estrutura o referente que corresponde aos argumentos do verbo. Assim, podemos dizer que o verbo manifesta flexão de pessoa, número (e ainda em aspecto), mas não há incorporação de afixo locativo.

Vamos ilustrar com os exemplos a seguir:

(a)

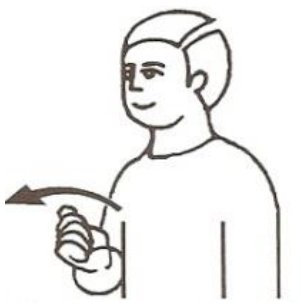

DAR

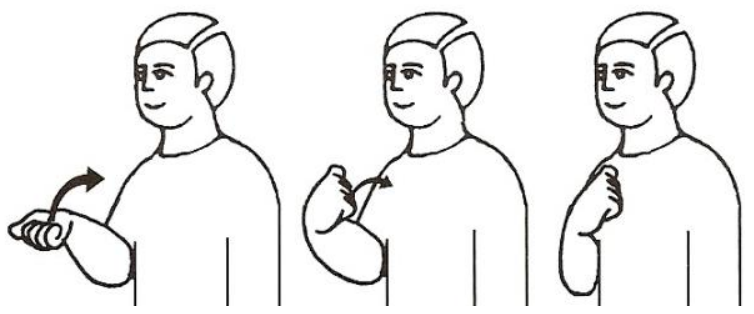

DAR-ME

Fonte: Capovilla e Raphael (2001, p.493 e 495)

Ferreira-Brito (1995) e Felipe (1998) afirmam que o item lexical 1-DAR-2 / 1-DAR-3 ('eu te dou'/ 'eu dou para ele(a)'; 1-DAR-1 ('eu dou para mim'), conforme a figura anterior, apresenta a configuração de mão com a palma da mão para cima, e o movimento parte de quem 'dá', que é o sujeito, em direção à pessoa que 'recebe', que o 
objeto. Ainda, a palma da mão fica voltada para a direção de quem está recebendo, se é, por exemplo, para o sinalizador 2-DAR-1 ('você me deu') e para a $3^{\text {a }}$ pessoa 2-DAR-3 ('você deu para ele(a)'). Vemos que o parâmetro da orientação de mão e o parâmetro da direção do movimento são diferentes, mas os outros parâmetros, como a configuração de mão e o ponto de articulação, são os mesmos. Portanto, os verbos anteriores são verbos com concordância. Diferentemente, nos verbos simples e nos verbos espaciais, o movimento e a orientação da mão não estão relacionados com a função sintática de sujeito e de objeto.

(b)

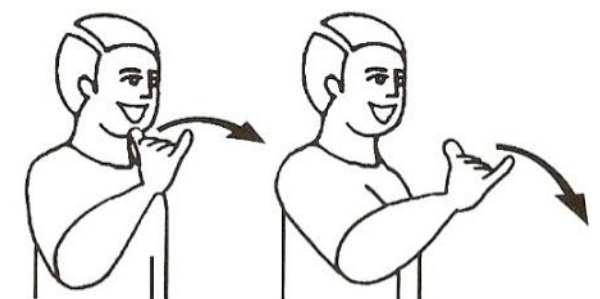

AVISAR

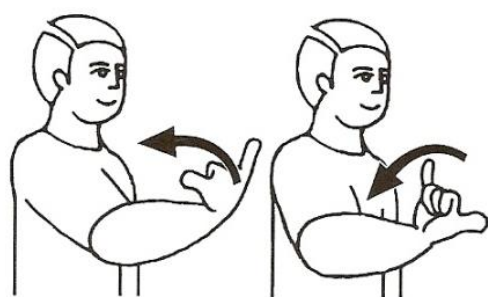

AVISAR-ME

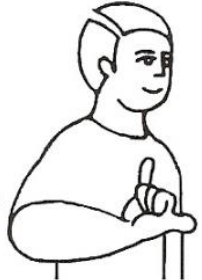

Fonte: Capovilla e Raphael (2001, p.252)

O verbo 1-AVISAR-2 / 1-AVISAR-3 apresenta parâmetros orientação da mão e movimento diferente do verbo 2-AVISAR-1 / 2-AVISAR-3, ou seja, a orientação da mão do verbo AVISAR é contralateral, no primeiro caso, e ipsilateral, no segundo caso.

Os verbos apresentados anteriormente são de concordância. De acordo com Ferreira (2013, p. 42), “a flexão (concordância) de pessoa e número é marcada pela direcionalidade do sinal, ou seja, o movimento que se faz do argumento sujeito na direção do argumento objeto." E ainda nas palavras de Meir et al (2008, p. 87), os verbos acima "codificam o papel sintático dos argumentos, como as características de pessoa e número através da direção do movimento das mãos e a posição das palmas."

Nosso objetivo ao comparar o sistema pronominal em português e em LIBRAS foi no sentido de mostrar que as línguas compartilham a propriedade de ter um sistema pronominal baseado na distinção entre as três pessoas do discurso. No entanto, existem diferenças entre as duas línguas, que afetam a marcação dos referentes. Essas diferenças estão relacionadas principalmente à diferença na modalidade oral-auditiva e visualespacial, uma vez que, na LIBRAS, os referentes são marcados por apontação de um ponto no espaço, ou por um movimento direcional para os pontos em que estão 
localizados os referentes, ou seja aquele que fala ( $1^{\mathrm{a}}$ pessoa), aquele com quem se fala ( $2^{\mathrm{a}}$ pessoa) e aquele de quem se fala ( $3^{\mathrm{a}}$ pessoa).

Nossa hipótese de trabalho é que a L1 é o estado mental inicial na aquisição da L2. Portanto, nosso objetivo é verificar em que medida a diferença entre a LIBRAS e o português interfere no desenvolvimento da interlíngua. É o que vamos apresentar nos capítulos 4 e 5 desta dissertação. 


\section{ANALISANDO OS DADOS DA INTERLÍNGUA}

\subsection{Constituição do corpus da pesquisa}

Neste capítulo, apresentamos uma análise dos dados colhidos nas produções escritas feitas pelos participantes surdos. Aplicamos os testes em atividades em sala de aula, que resultaram na produção escrita.

A coleta de dados ocorreu no ano de 2015 na Escola para Surdos de Uberaba/MG, que cedeu o espaço para a pesquisa e tem como modelo a educação bilíngue. Os professores ouvintes e surdos ministram conteúdos específicos da grade curricular em LIBRAS e na modalidade escrita de português como segunda língua. Os conteúdos são contextualizados numa didática compatível com a realidade dos alunos surdos, utilizando recursos visuais, com imagens e sistemas gráficos adequados, além da língua de sinais como língua de instrução e do português escrito (a questão linguística será retomada).

A seguir, descrevemos os procedimentos utilizados na preparação e aplicação dos roteiros das coletas realizadas. O corpus da pesquisa compõe-se de textos produzidos pelos 19 participantes surdos matriculados no sistema público do ensino fundamental de $4^{\circ}$ ao $9^{\circ}$ ano, distribuídos em 2 (dois) grupos: $4^{\circ}$ a $5^{\circ}$ ano e $8^{\circ}$ a $9^{\circ}$ ano, que gentilmente aceitaram participar da pesquisa. A faixa etária é de 10 a 20 anos, todos são usuários de LIBRAS e apresentam surdez entre moderada, severa e profunda. No registro dos dados, identificamos os participantes por meio de iniciais de seu nome em letra maiúscula e da escolaridade, em parênteses com idade.

Inicialmente, o pesquisador frequentou as atividades na sala de aula durante quase em dois meses. Em seguida, o trabalho da estrutura argumental que permitiu a coleta dos dados foi produzido em frases, apresentadas aos participantes surdos. Também foram apresentados quadrinhos criados com imagens para representar ações, sem textos, e o surdo deveria colocar frases para representar os sentidos das imagens, em que deveriam aparecer sujeito e complemento/ argumento externo e argumento interno. Essas formas da produção escrita portuguesa como segunda língua envolvem o desenvolvimento linguístico, que, por hipótese, corresponde ao desenvolvimento do seu nível escolar. 
Nas seções seguintes, serão apresentados os resultados da pesquisa de campo, as atividades pedagógicas com os participantes surdos, que contribuíram para coletar os dados para o surdo realizar sua produção escrita, e será analisado o corpus do uso sintático da estrutura argumental. Como será demonstrado, o resultado é a ausência dos argumentos interno e externo nas posições sintáticas, mas existe uma tendência de aumento no preenchimento dos argumentos quando comparamos os 2 níveis escolares.

\subsection{Trabalho de campo}

No presente trabalho, a pesquisa de campo se propõe a conciliar as linhas de abordagem quantitativa e qualitativa. A abordagem quantitativa é utilizada para a quantificação dos dados que nós trazemos a coleta de informações em questionários, por meio de técnicas estatísticas. A qualitativa representa uma observação dos participantes surdos para verificar o desenvolvimento de sua aprendizagem. Além de observar o espaço escolar, identificamos grau de afinidade dos alunos surdos usuário de LIBRAS (L1), percebemos que eles estão tendo dificuldade no processo do uso da língua portuguesa (L2) (modalidade escrita). Trazemos essas informações para facilitar a análise dos dados da pesquisa, apenas informalmente.

Historicamente, a Escola para Surdos Dulce de Oliveira foi criada em 1967 com ajuda dos rotarianos. Fica localizada na Rua Espir Nicolau Bichuete, 230 - São Benedito, Uberaba/MG. Antes de tudo, a escola começou quando a senhora Dulce resolveu ensinar seus sobrinhos surdos pela primeira vez e também outras crianças surdas da região a se alfabetizaram. Por isso abriu as portas de sua própria casa e depois construiu a Escola que teve o terreno doado pela Dulce.

Observamos que a infraestrutura nessa escola é composto por térreo e plano em forma de cobertura, todos os cômodos são divididos por meio de: diretoria, sala de coordenação, sala para reuniões, salas de aula, laboratório de informática, cozinha, banheiros masculino e feminino, pátio para intervalo em área maior, áreas interna e externa para lazer e outros espaços.

Portanto, a Escola para Surdos de Uberaba e região vem desenvolvendo experiências pedagógicas que promovem a construção do conhecimento do sujeito surdo, possibilitando sua inclusão social. Para ministrar as aulas, os docentes surdos e ouvintes são cedidos pela Prefeitura Municipal de Uberaba/MG, e os membros do 
Rotary Clube com empresas parceiras, e cidadãos solidários, proporcionam recursos financeiros para ajudar da escola.

Além do ensino, a instituição oferece os seguintes serviços: Atendimento Educacional Especializado - AEE, Atendimento psicológico para os familiares e alunos, atendimento fonoaudiólogo, atendimento com terapeutas ocupacionais com parceria de outra instituição. Com a finalidade de promover o ensino e a educação das pessoas surdas a partir de estimulação precoce desde os três anos de idade, do ensino infantil ao ensino fundamental. Alguns alunos estudam em período integral. Os alunos surdos são inseridos na escola regular que tem intérpretes de LIBRAS para entender melhor suas atividades acadêmicas, interdisciplinares e os conhecimentos para se tornarem cidadãos e formar sua escolaridade completa.

Nesta instituição, o trabalho pedagógico é desenvolvido por meio de projetos e os alunos são acompanhados por um docente que possui domínio em LIBRAS e utilizase desta língua para ministrar os conteúdos das diversas disciplinas (Matemática, História, Inglês, Português, Ciências, Geografia). Além disso, os alunos também ficam juntos com outros docentes surdos e ouvintes (todos se comunicam em LIBRAS) e tem aulas de Língua Portuguesa como L2, Educação Física, Artes e Informática.

Sabemos que esses conteúdos curriculares são apresentados aos alunos surdos por meio da LIBRAS, que é adotada como a primeira língua natural aos surdos. Nesse sentido, citam-se a experiência linguística e as peculiaridades da cultura surda, que, de acordo com Quadros (2006), aborda as características das experiências visuais que os surdos traduzem por meio de sua língua de sinais. Além disso, é trabalhada paralelamente a Língua Portuguesa escrita, como segunda língua (L2), reconhecendo, como previsto na Lei 10.436, que a LIBRAS possui estrutura gramatical própria, que se distingue do português. No entanto, as duas línguas têm propriedades em comum. Por essa razão, podemos afirmar que o ser humano pode sempre aprender uma nova língua.

O objetivo desse trabalho de campo é observar e pesquisar os alunos surdos, investigando como é o desenvolvimento do português como segunda língua, na modalidade escrita.

Antes disso, fizemos uma explicação dos conteúdos da gramática do português que seriam trabalhados nas atividades. As fotos abaixo mostram à experiência realizada para trabalhar as frases contextualizadas a fim de unir prática e teoria. 

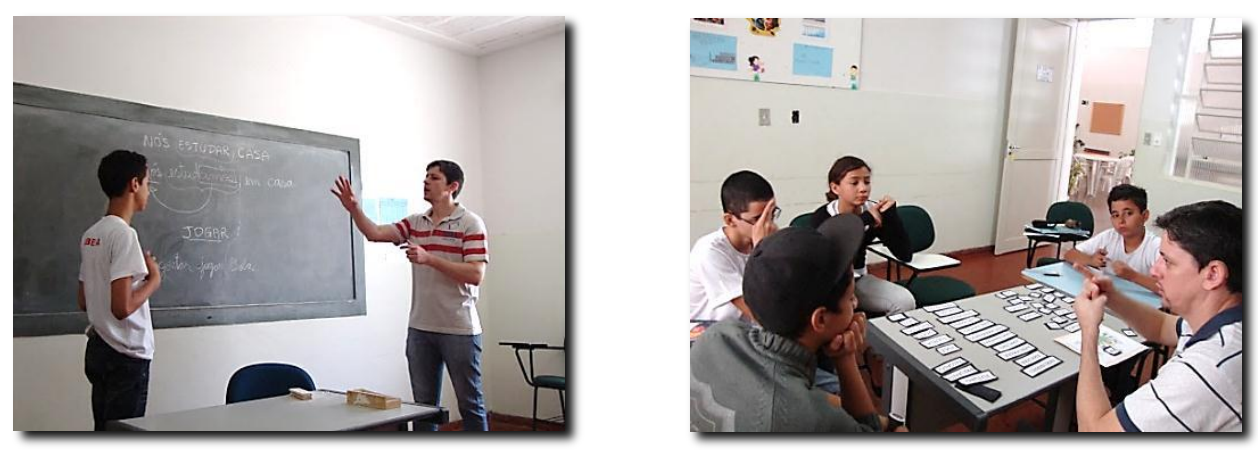

Fotos tiradas pela professora Marília em aula de português.

A entrada em campo ocorreu mediante apresentação da pesquisa inicial para a direção, coordenação pedagógica, equipe docente e alunos surdos. Os participantes surdos se envolveram na realização da pesquisa neste espaço educacional e foi solicitada uma carta de aceite institucional à direção. Além disso, o pesquisador responsável solicitou os termos e as autorizações para os familiares e alunos surdos. Foi assinado o termo de autorização para utilização de imagem, o termo de consentimento livre e esclarecido. Todas as documentações acima foram enviadas ao comitê de ética e a pesquisa foi aprovada.

\subsection{Apresentação dos dados}

Coletamos os dados para investigar a realização sintática da estrutura argumental em língua portuguesa como L2 na interlíngua de surdos. Os dados descritos e analisados do corpus apresentam a extrema importância da pesquisa quantitativa para que possamos investigar a estrutura sintática dos enunciados produzidos pelos surdos em contexto educacional, considerando a realização dos argumentos interno e externo.

Assim sendo, investigamos, nesta pesquisa, o processo de aprendizagem da língua portuguesa por surdos usuários da LIBRAS. Por meio desses dados, observamos a identificação das principais características dos participantes surdos. A seguir, apresentamos em gráficos o resultado do questionário que apresentamos aos estudantes surdos (Anexo 1), no qual investigamos os seguintes aspectos:

1. Idade de acesso à LIBRAS (L1)

2. Auto-avaliação do conhecimento de português (L2)

3. Idade da alfabetização em português

4. Tipo de surdez 
5. Característica do grau de surdez

6. Acesso à língua oral: Oralização e Prótese auditiva

7. Capacidade de leitura de legenda em português (escrito)

8. Característica dos pais dos participantes quanto à surdez

9. Característica da família dos participantes quanto a ter parente surdo

10. Característica da família quanto ao uso de LIBRAS.

Não vamos aprofundar a investigação dos aspectos que consultamos no questionário. Conforme mencionamos anteriormente, nossa hipótese de trabalho é que os estudantes mais adiantados vão ter um desempenho melhor no português (escrito) (L2) do que os estudantes das séries iniciais, porque receberam mais input linguístico, nas atividades escolares durante as aulas. Se essa hipótese for confirmada, e assumindo a importância do acesso precoce à língua de sinais, da auto-estima do estudante, e dos demais fatores, propomos fazer uma investigação mais detalhada de cada fator em estudos futuros.

Passamos agora para a apresentação dos gráficos de cada item consultado no questionário. Iniciamos pela investigação do conhecimento de LIBRAS como L1.

Gráfico 1: Características da aquisição de L1 (IDADE) pelos participantes surdos. 


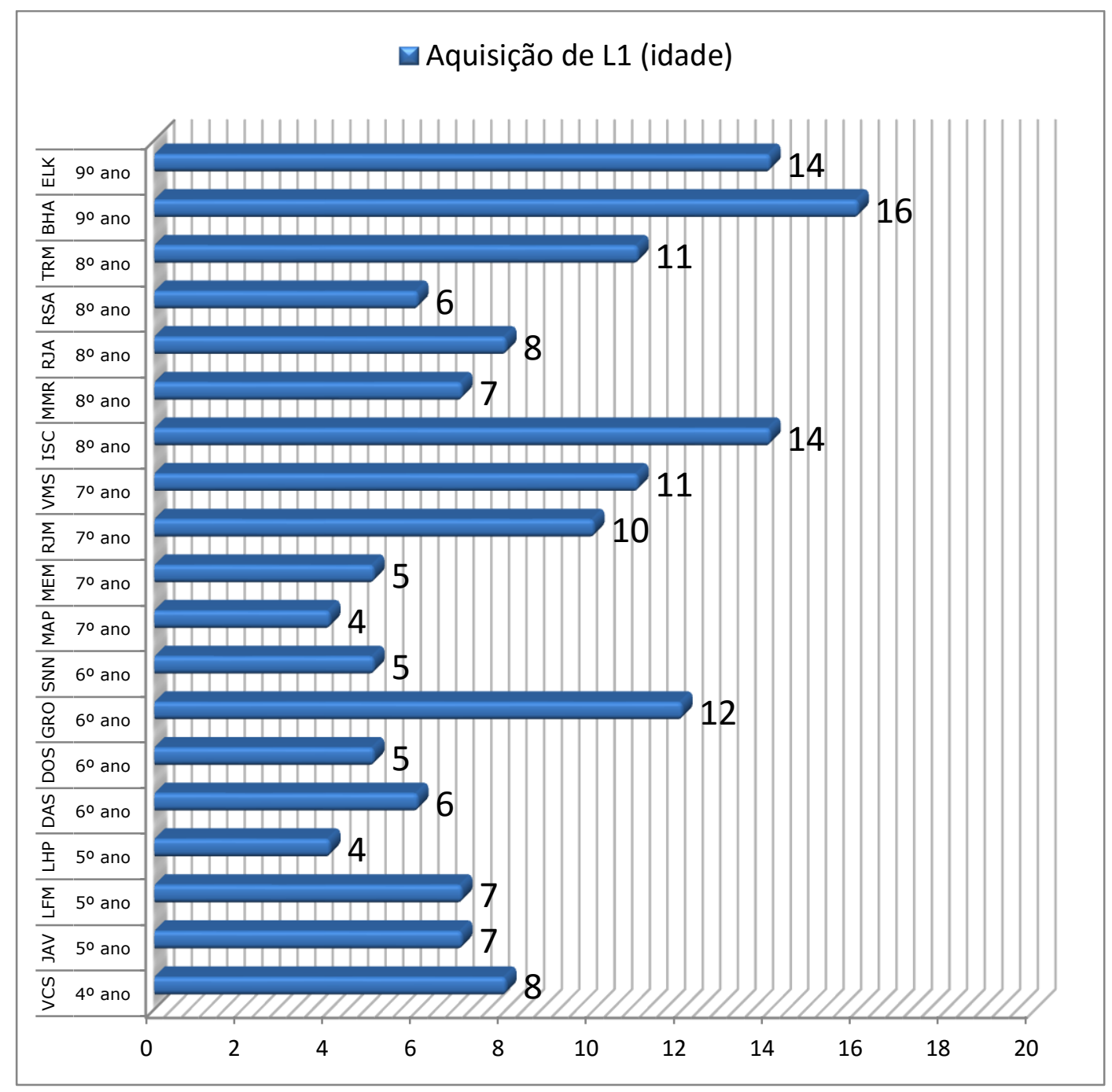

Gráfico 1: Características da aquisição de L1 (IDADE) pelos participantes surdos.

O gráfico mostra a idade do participante surdo quando teve acesso à LIBRAS (L1). Como se pode observar, nas séries finais $\left(8^{\circ}\right.$ e $9^{\circ}$ ano), de 7 participantes, 3 tiveram acesso à LIBRAS depois de 12 anos. Do $4^{\circ}$ ao $7^{\circ}$ ano, somente 2 participantes, de um total de 12, adquiriram LIBRAS depois de 11 anos. Inversamente, no grupo do $4^{\circ}$ ao $7^{\circ}$ ano, notamos que 9 participantes adquiriram a LIBRAS antes dos 8 anos. Muitos autores destacam que o acesso precoce à língua de sinais é muito importante para o desenvolvimento cognitivo da criança. O gráfico mostra que existem avanços, ou seja, aumentou o número de crianças que chegam na escola com acesso à língua de sinais.

No gráfico 2, a seguir, apresentamos a resposta dos participantes em relação a como eles avaliam o conhecimento do português (escrito) L2.

Gráfico 2: Características da aquisição de L2 pelos participantes surdos. 


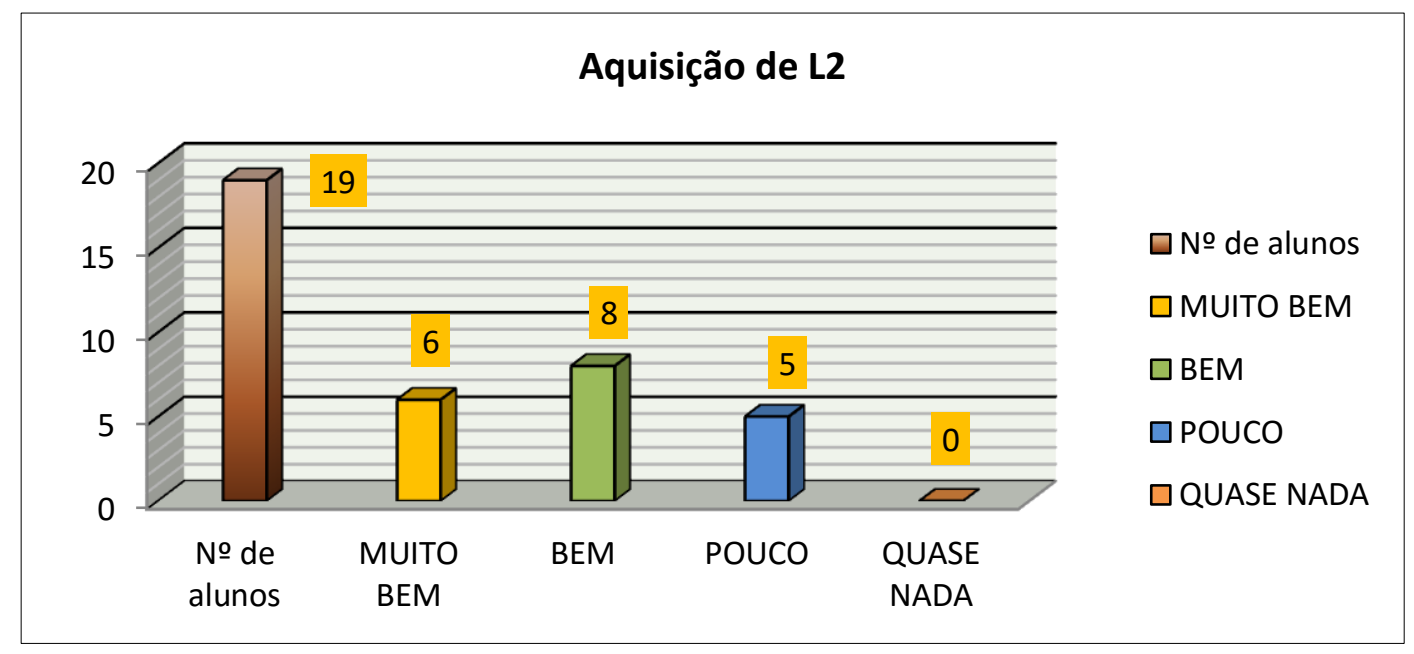

Gráfico 2: Características da aquisição de L2 pelos participantes surdos.

Esse gráfico mostra que a maioria dos participantes (14) avalia que faz uso do português (escrito) (L2) BEM ou MUITO BEM. Apenas 5 (cinco) participantes avaliam que seu conhecimento é POUCO. Esse resultado mostra que os participantes se sentem confiantes em relação ao conhecimento da segunda língua. alfabetizados.

O gráfico 3 mostra a idade em que os participantes iniciaram a escola e foram

\section{Gráfico 3: Características do acesso na escola e sua alfabetização pelos participantes surdos.}

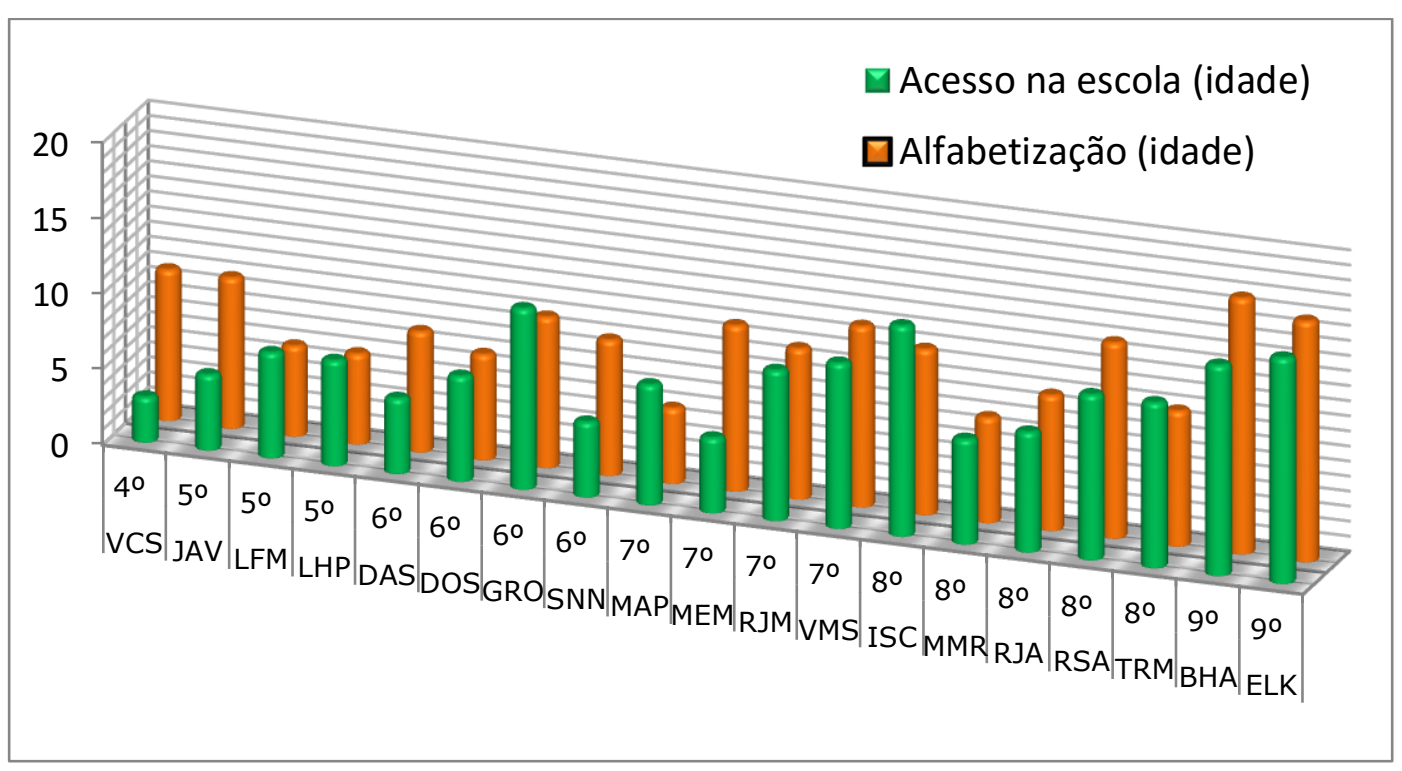

Gráfico 3: Características do acesso na escola e sua alfabetização pelos participantes surdos. 
O gráfico 3, acima, mostra a idade com que o surdo iniciou sua escolarização. Verificamos que alguns participantes acessaram a escola depois de serem alfabetizados. A alfabetização foi feita pelo parente familiar. Questionamos aos participantes surdos o período em que foram ter sua alfabetização e constatamos que para muitos deles a alfabetização é muito tardia, pois, para a maioria dos estudantes, a faixa etária é após os 10 anos de idade (11 estudantes).

A seguir, temos o gráfico do tipo de surdez dos participantes.

Gráfico 4: Características do tipo de surdez pelos participantes surdos.

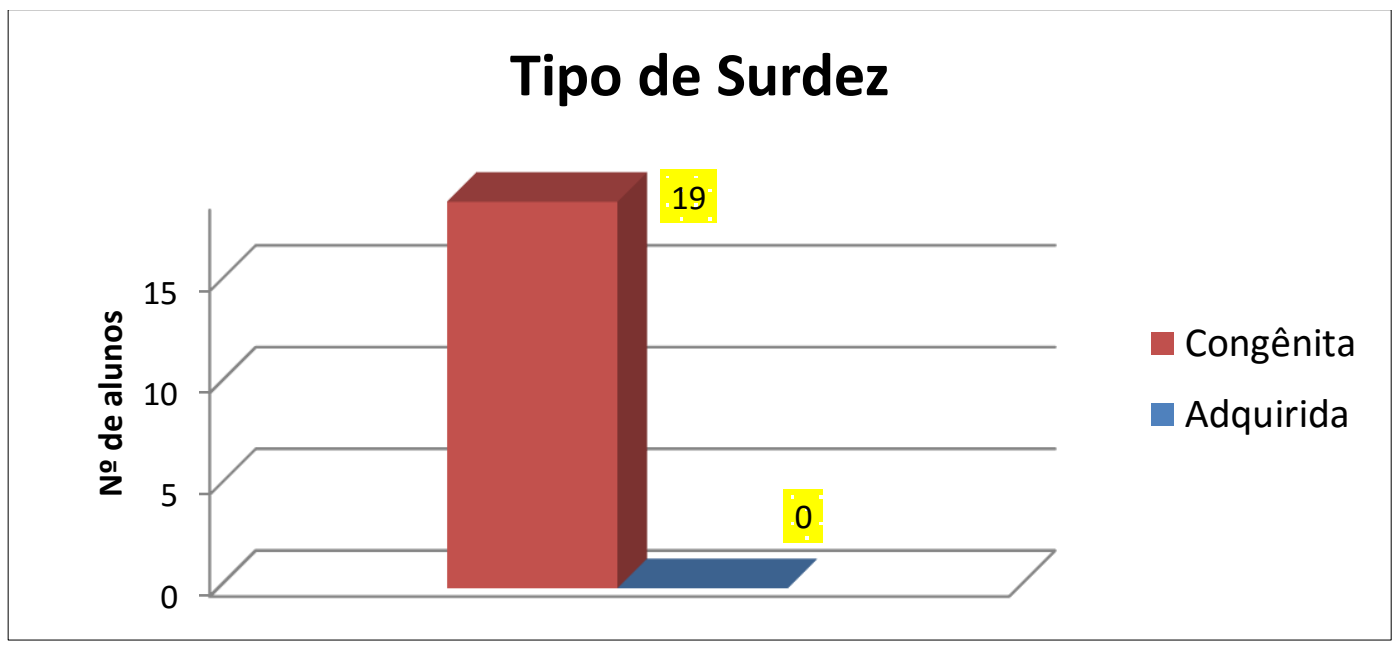

Gráfico 4: Características do tipo de surdez pelos participantes surdos.

O gráfico 4, acima, mostra que, em relação ao tipo de surdez, todos os participantes têm surdez congênita, ou seja, são surdos de nascença. Essa informação é importante, por dois motivos: primeiro porque temos uma amostra homogênea, e segundo, porque a surdez congênita indica que não existiu acesso à língua oral em condições normais para nenhum dos participantes. Essa informação deve ser observada junto com a informação sobre o grau de surdez.

O gráfico a seguir indica o grau de surdez dos participantes.

Gráfico 5: Características do grau de surdez pelos participantes surdos. 


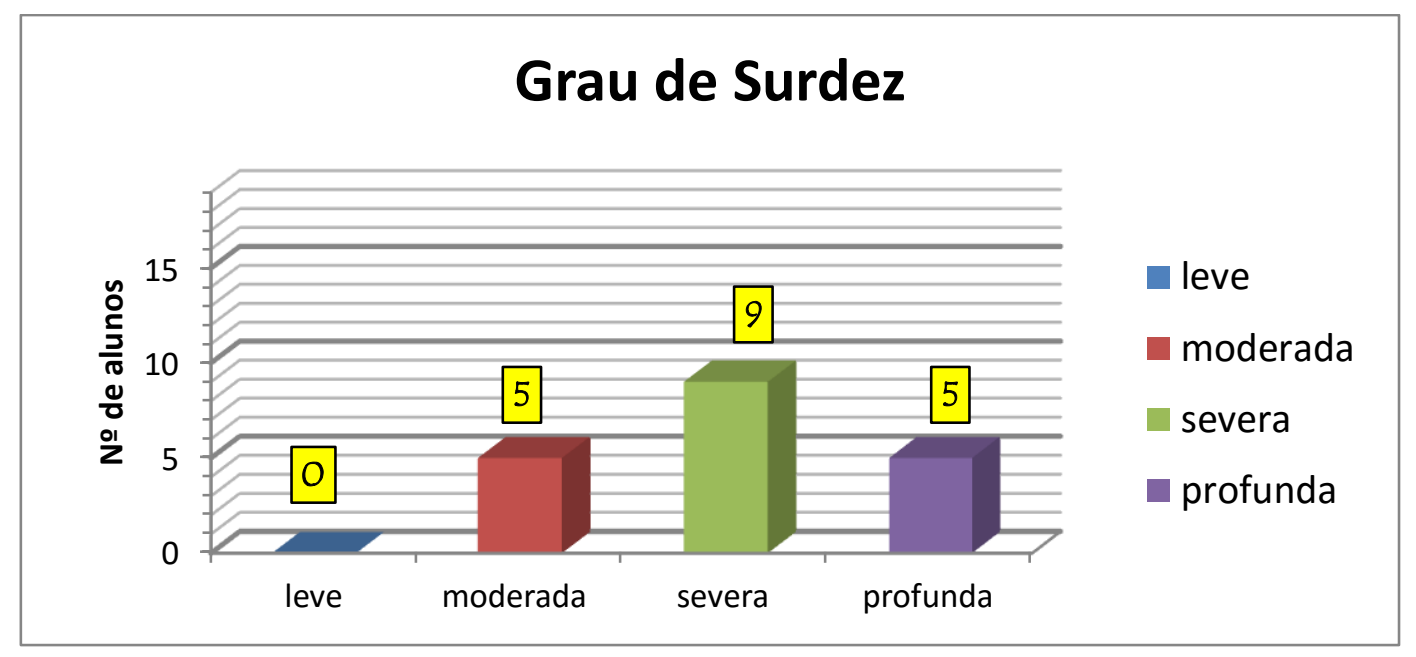

Gráfico 5: Características do grau de surdez pelos participantes surdos.

No gráfico 5, verificamos que a maioria dos participantes (14) tem surdez profunda e severa. Essa condição pode ser considerada em conjunto, porque tem um efeito semelhante em relação ao acesso da língua oral. Também a surdez moderada traz dificuldade para o acesso à língua oral.

No próximo gráfico, mostramos o uso de prótese auditiva pelos participantes surdos, e a relação com a capacidade de oralizar.

\section{Gráfico 6: Características dos principais oralista e prótese auditiva pelos} participantes surdos.

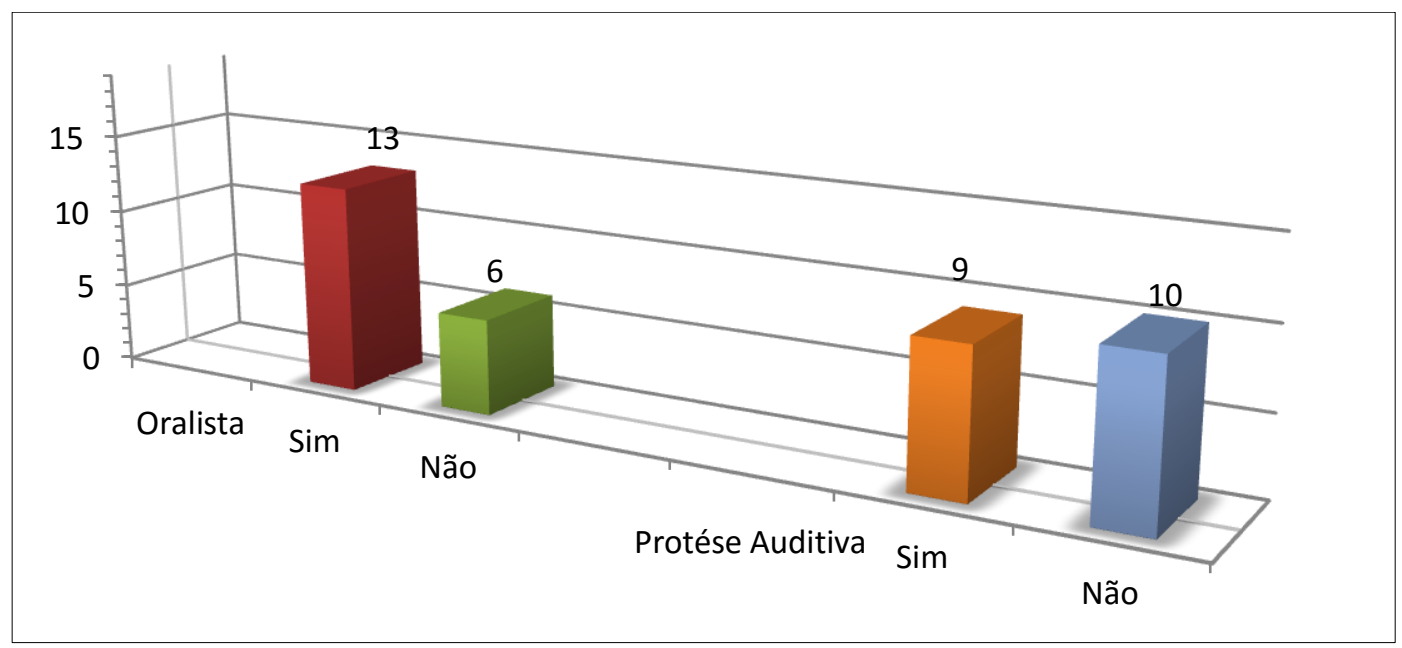

Gráfico 6: Características dos principais oralista e prótese auditiva pelos participantes surdos. 
O gráfico mostra que a maioria dos participantes consegue oralizar. Chama a atenção que 10 participantes não usam prótese auditiva, e entre eles ainda há pelo menos 4 que conseguem oralizar. Isso mostra que não é necessário usar prótese auditiva para oralizar.

No gráfico a seguir, verificamos como os participantes avaliam sua capacidade de ler as legendas.

\section{Gráfico 7: Capacidade de escrever, ler e ver TV com legenda em português}

$$
\text { (escrito) - auto-avaliação }
$$
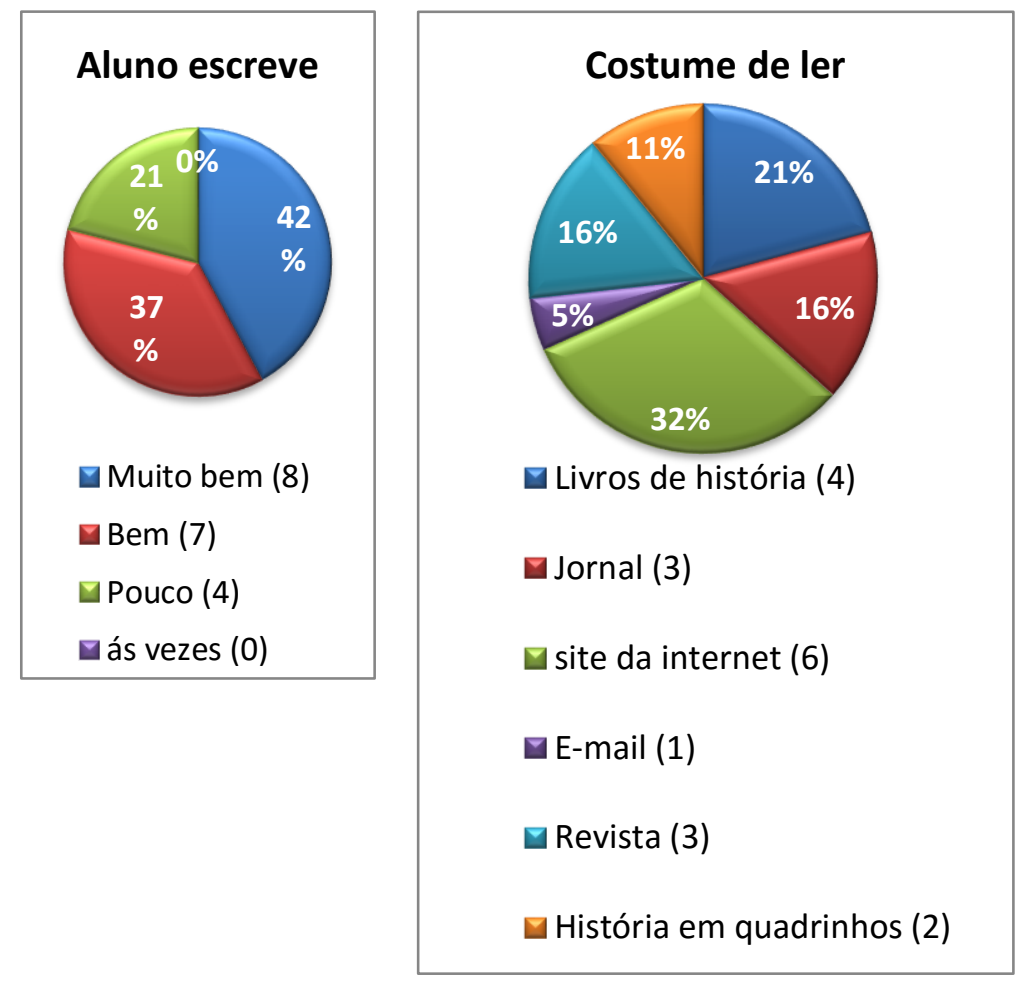

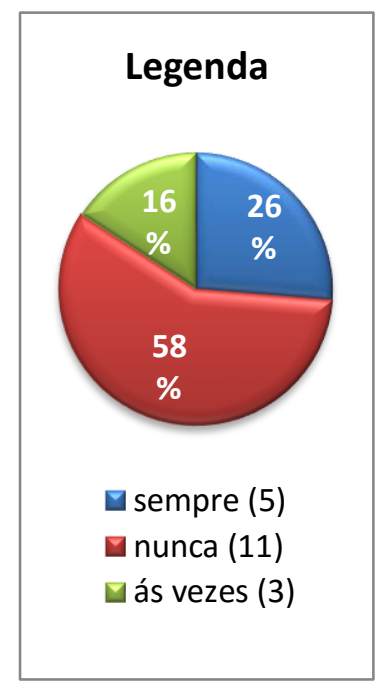

Gráfico 7: Capacidade de escrever, ler e ver TV com legenda em português (escrito) - auto-avaliação.

Observamos com esses gráficos como aluno avalia a própria capacidade de escrever, ler e ver TV com legenda. Notamos que ele avalia que lê 'muito bem' em português com $42 \%$, e ainda 'bem' (37\%). Outra fatia avalia que escreve 'pouco', com $21 \%$. Nenhum participantes avaliam que lêem 'às vezes'. Para segundo gráfico, que avalia que tipo de materiais o aluno tem costume de ler, os recursos digitais eletrônicas no site da internet foi a maior escolha (32\%); em segundo lugar, os livros de história (21\%); tem duas fatias igualadas o jornal e as revistas, pois estão com 16\%; as histórias em quadrinhos ficaram em quarto lugar (11\%), e existem poucos usos do e-mail (5\%). O terceiro gráfico mostra que a maioria dos participantes surdos nunca lê a legenda (58\%), outra 
fatia (26\%) sempre vê a legenda, mas têm dificuldade de entender os sentidos na estrutura sintática, e em último lugar, são os participantes que conseguem ler e entender a legenda de vez em quando (16\%).

No gráfico a seguir, apresentamos a característica dos pais dos participantes em relação à surdez.

Gráfico 8: Características dos pais dos participantes quanto à surdez

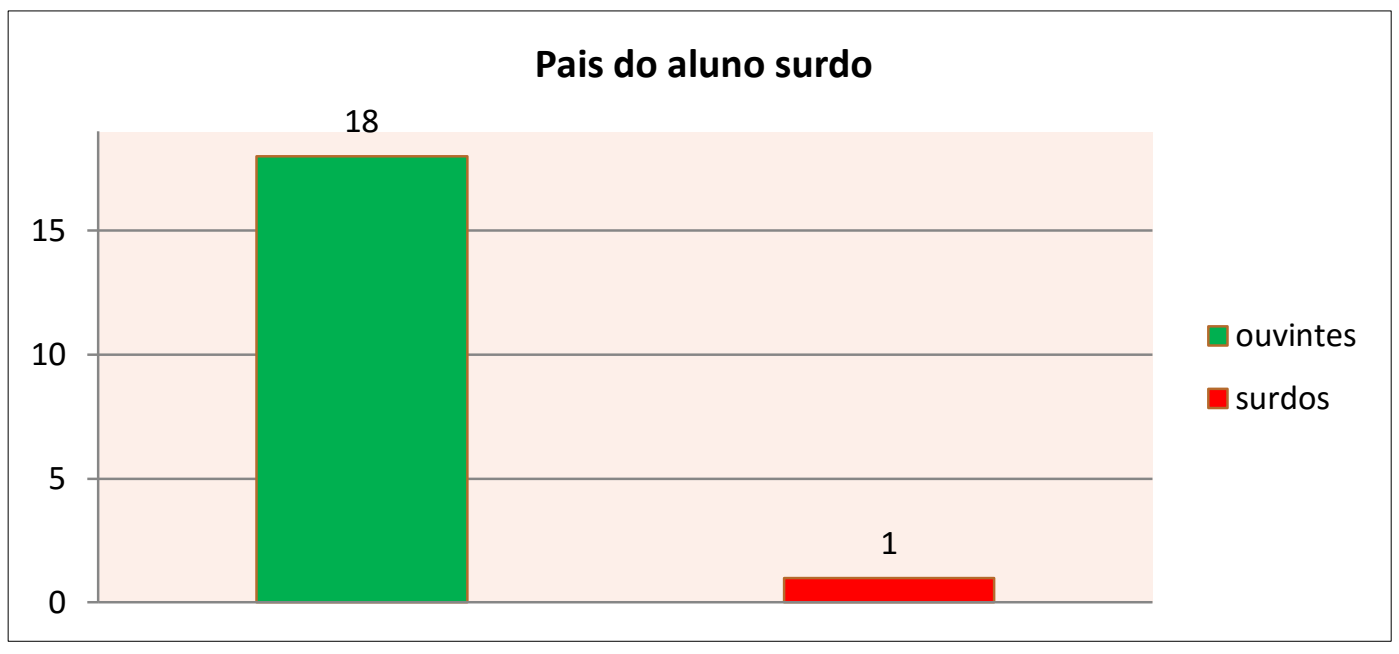

Gráfico 8: Características dos pais dos participantes quanto à surdez

Calculamos os participantes surdos que têm pais surdos ou ouvintes, e observamos que 18 participantes têm pais ouvintes e somente um participante tem pais surdos. A consequência é que a maioria dos pais ouvintes estão tendo um pouco de dificuldade de se comunicar com filho surdo usuário de L1. Alguns pais estão interessados em aprender a língua de sinais para poder conversar melhor e ajudar os filhos a desenvolver seu estudo.

O gráfico a seguir mostra se existem outras pessoas surdas na família.

Gráfico 9: Características da família dos participantes quanto a ter parente surdo 


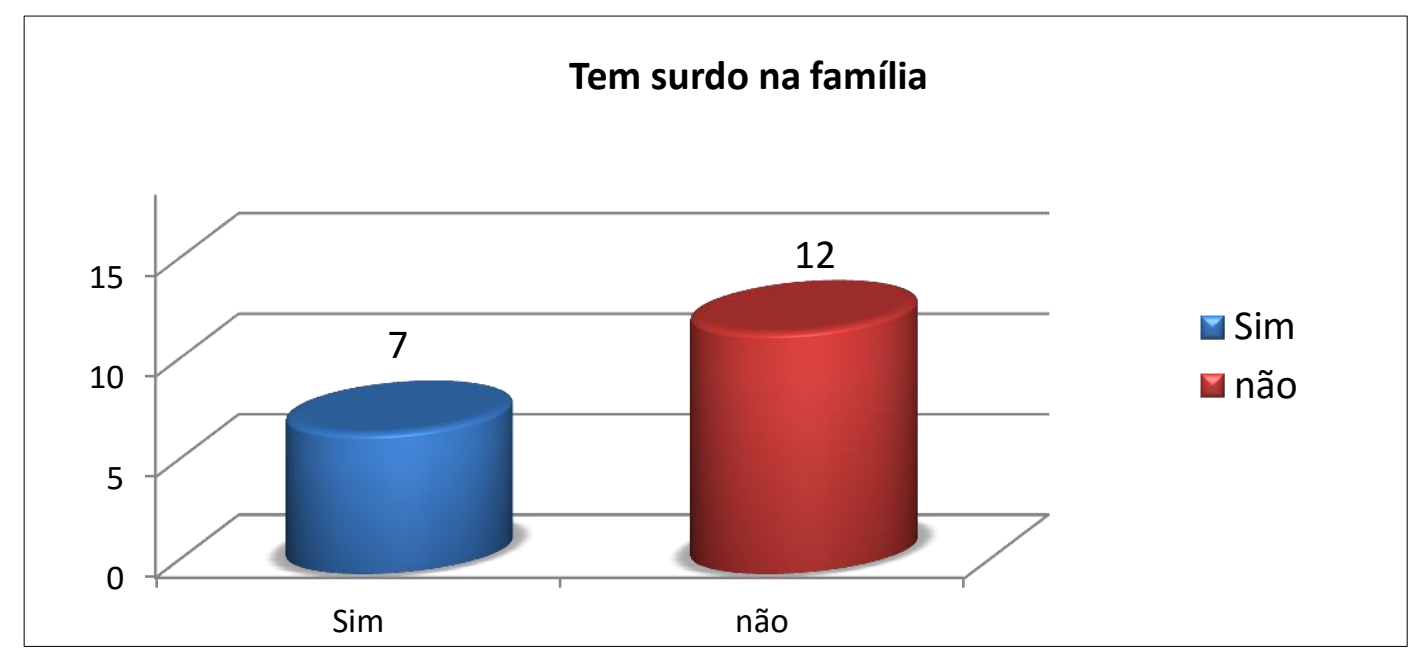

Gráfico 9: Características da família dos participantes quanto a ter parente surdo.

Questionamos para saber se na família dos participantes existe algum parente surdo. A maioria dos participantes surdos dizem que não (12), somente alguns informam que existem parentes com surdez, como primo, irmão, tio (7). Como sabemos, a presença de um familiar surdo pode facilitar a aquisição e o uso da língua sinais, mas essa questão não foi investigada.

O gráfico a seguir mostra a característica dos pais quanto ao uso de LIBRAS.

\section{Gráfico 10: Características da família quanto ao uso de LIBRAS}

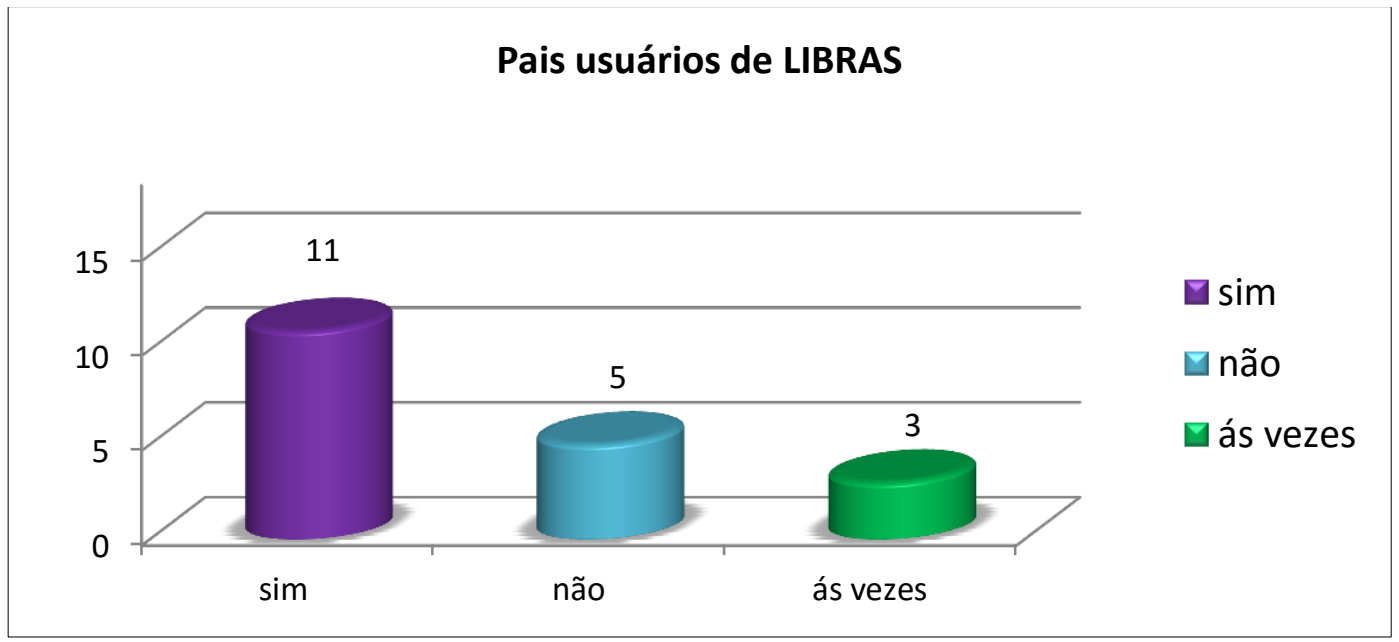

Gráfico 10: Características da família quanto ao uso de LIBRAS

Observamos que quase a metade dos pais sabem se comunicar em LIBRAS, e também um pouco menos da metade não sabem. Alguns pais se comunicam 'às vezes' com o 
surdo em LIBRAS. Alguns pais moram em outra cidade e têm dificuldade para aprender LIBRAS.

Mostramos todos gráficos acima, para registrar que essas informações da pesquisa são de suma importância para investigar a identificação e a situação linguística e social dos participantes surdos. No entanto, deixamos para aprofundar essas questões em estudos futuros. A seguir, trabalhamos para analisar os dados coletados que foram produzidos pelos participantes surdos de séries diferentes. Esse resultado permite testar nossa hipótese em relação à interferência da L1 na interlíngua (português L2), considerando as diferenças nos sistemas pronominais e na realização sintática dos argumentos. Nosso objetivo é verificar se os dados têm ausência dos sintagmas nominais e de pronomes na posição de sujeito e/ou do objeto, na realização dos argumentos interno e externo.

\subsection{Análise dos dados}

Nesta seção, primeiramente, apresentamos a análise e discussão dos dados das frases contextualizadas e da produção de textos dos participantes surdos. Fizemos um estudo com o propósito levantar uma hipótese em relação à interferência da L1. Para tanto, investigamos os sentidos das sentenças em sua estrutura sintática na interlíngua do aprendiz surdo de português (escrito) como L2. Após fazer a coleta dos dados, iniciamos a etapa de análise em diversos textos dos alunos selecionados, buscando-se identificar as principais alterações morfossintáticas da estrutura argumental. A coleta foi feita a partir das produções realizadas em sala de aula, junto ao usuário de LIBRAS, na modalidade escrita em língua portuguesa como L2. Antes de serem produzidos na escrita da L2, os textos foram discutidos e produzidos em LIBRAS. Os participantes surdos selecionados (19 alunos) fizeram 4 (quatro) atividades, mas somente duas foram selecionadas para o presente estudo.

A análise será apresentada para cada participante, de acordo com o nível de escolaridade. Os alunos foram divididos em dois grupos: Grupo A, do $4^{\circ}$ e $5^{\circ}$ com 4 alunos e Grupo B, do $8^{\circ}$ e $9^{\circ}$ ano com 7 alunos. Examinaremos as produções realizadas que comprovam a compreensão no uso de português (escrito) como L2. 


\subsubsection{Atividade 1: ordem dos termos e tipo de verbo (VI; VTD; VTDI)}

A primeira atividade proposta colocou 13 itens lexicais da categoria verbo. Os participantes deveriam criar uma frase com cada verbo. Todos os verbos possuem argumentos. Analisamos a ordem das palavras como sujeito-S, verbo-V, objeto-O, e também o preenchimento de cada posição sintática. Verificamos as produções realizadas. Os participantes foram separados em grupos. No Grupo A, estão os participantes do $4^{\circ}$ e $5^{\circ}$ ano, no grupo $B$, estão os participantes do $8^{\circ}$ e $9^{\circ}$ ano.

\section{Grupo A: $4^{\circ}$ e $5^{\circ}$ ano}

Para a análise dos resultados, considere a tabela a seguir, em relação à realização dos argumentos.

\begin{tabular}{|c|c|c|c|}
\hline $\mathrm{S} \phi$ & sujeito nulo & $\mathrm{S}$ & sujeito \\
\hline $\mathrm{O}_{1} \phi$ & objeto nulo & $\mathrm{O}_{1}$ & objeto direto \\
\hline $\mathrm{O}_{2} \phi$ & Objeto (indireto) nulo & $\mathrm{O}_{2}$ & objeto indireto \\
\hline
\end{tabular}

Vejamos a seguir o quadro A1, que mostra os dados que foram produzidos pelos alunos. O primeiro quadro mostra a produção de sentenças com verbos transitivos diretos (VTD) e dois argumentos, considerando a ordem dos termos (S/V/O) e a realização dos argumentos na posição de sujeito e de objeto (direto e indireto).

Quadro A1 - Ordem dos termos e VTD - Participantes de $4^{\circ}$ ao $5^{\circ}$ ano / 10 a 11 anos:

\begin{tabular}{|c|c|c|c|c|c|}
\hline Verbos & ARG. & VC4(10) & JA5(11) & LF5(11) & LH5(11) \\
\hline $\begin{array}{l}\text { 'entender' } \\
\text { (VTD) }\end{array}$ & 2 & $\mathrm{~S} \phi \mathrm{VO}_{1} \phi$ & $\mathrm{SVO}_{1} \phi$ & $\mathrm{S} \phi \mathrm{O}_{1} \mathrm{~V}$ & $\mathrm{~S} \phi \mathrm{VO}_{1} \phi$ \\
\hline $\begin{array}{c}\text { 'ter' } \\
\text { (VTD) }\end{array}$ & 2 & $\mathrm{~S} \phi \mathrm{VO}_{1}$ & $\mathrm{SVO}_{1} \phi$ & $\mathrm{SVO}_{1}$ & $\mathrm{SVO}_{1}$ \\
\hline $\begin{array}{l}\text { 'estudar' } \\
\text { (VTD/VI) }\end{array}$ & 2 & $\mathrm{O}_{2}+\mathrm{SVO}_{1}$ & $\mathrm{SVO}_{1} \phi$ & $\mathrm{SVO}_{1} \phi$ & $\begin{array}{c}\mathrm{O}_{2} \phi+\mathrm{S} \phi \mathrm{VO}_{1} \\
\phi\end{array}$ \\
\hline $\begin{array}{l}\text { 'aprender' } \\
\text { (VTD/VI) }\end{array}$ & 2 & \#\#\# & $\mathrm{SVO}_{1}$ & $\mathrm{SVO}_{1}$ & $\mathrm{~S} \phi \mathrm{VO}_{1}$ \\
\hline $\begin{array}{l}\text { 'sentir' } \\
\text { (VTD) }\end{array}$ & 2 & $\mathrm{VSO}_{1}$ & $\mathrm{~S} \phi \mathrm{VO}_{1}$ & $\mathrm{~S} \phi \mathrm{VO}_{1} \phi$ & $\mathrm{S} \phi \mathrm{VO}_{1}$ \\
\hline $\begin{array}{l}\text { 'responder' } \\
\text { (VTD) }\end{array}$ & 2 & $\mathrm{~S} \phi \mathrm{VO}_{1} \phi+\mathrm{O}_{2}$ & $\mathrm{~S} \phi \mathrm{VO}_{1}$ & $\mathrm{~S} \phi \mathrm{VO}_{1}$ & $\mathrm{~S} \phi \mathrm{VO}_{1}$ \\
\hline $\begin{array}{l}\text { 'conhecer' } \\
\text { (VTD) }\end{array}$ & 2 & $\mathrm{~S} \phi \mathrm{VO}_{1} \phi$ & $\mathrm{S} \phi \mathrm{VO}_{1}+\mathrm{O}_{2}$ & $\mathrm{~S} \phi \mathrm{VO}_{1}$ & $\mathrm{SVO}_{1}$ \\
\hline
\end{tabular}


Mostramos o quadro A1. Destacamos que os verbos transitivos diretos relacionam os argumentos. Quanto à complementação, os predicados necessitam preencher o lugar da posição do sujeito e objeto. Assim, analisamos os dados coletados pelos participantes surdos de $4^{\circ}$ ao $5^{\circ}$ ano. O participante identificado como LH5(11) é portador de deficiência intelectual e participou atividade sem cobrança, mas expressou sua idéia para escrever em português. Nossa hipótese é que, na sentença, $\mathrm{O}_{2}+\mathrm{SVO}_{1}$, o termo está na posição de tópico na estrutura sintática.

O quadro A1a mostra a quantificação das ordens encontradas.

Quadro A1a: VTD e ordem dos termos: total de dados

\begin{tabular}{|r|c|c|}
\hline \multicolumn{2}{|c|}{ ORDEM } & QTS \\
\hline $\mathrm{O}_{2}+\mathrm{SVO}_{1}=\mathrm{SVO}_{1}=$ & $\mathrm{SVO}$ & 6 \\
\hline $\mathrm{VSO}_{1}=$ & $\mathrm{VSO}$ & 1 \\
\hline $\mathrm{SVO}_{1} \phi=$ & $\mathrm{SV}$ & 4 \\
\hline $\mathrm{S} \mathrm{VO}_{1}+\mathrm{O}_{2}=\mathrm{S} \mathrm{VO}_{1}=$ & $\mathrm{VO}$ & 9 \\
\hline $\mathrm{O}_{2}+\mathrm{S} \phi \mathrm{VO}_{1} \phi={\mathrm{S} \phi \mathrm{VO}_{1} \phi+\mathrm{O}_{2}=\mathrm{S} \phi \mathrm{VO}_{1} \phi=}_{\mathrm{S} \phi \mathrm{O}_{1} \mathrm{~V}=}^{\mathrm{V}}$ & $\mathrm{OV}$ & 6 \\
\hline & & \\
\hline
\end{tabular}

Observamos o seguinte resultado: as sentenças que ocorrem na ordem básica SVO são 6. A ordem mais usada é VO (9). Somando as ordens SVO, SV e VO, que seguem o padrão de ordem básica, encontramos 19 dados. Em 6 dados observamos apenas o V. Dois dados não seguem a ordem básica - VSO e OV.

O quadro A1b apresenta os mesmos dados quantitativos, em um gráfico diferente.

Quadro A1b: VTD e ordem dos termos: total de dados

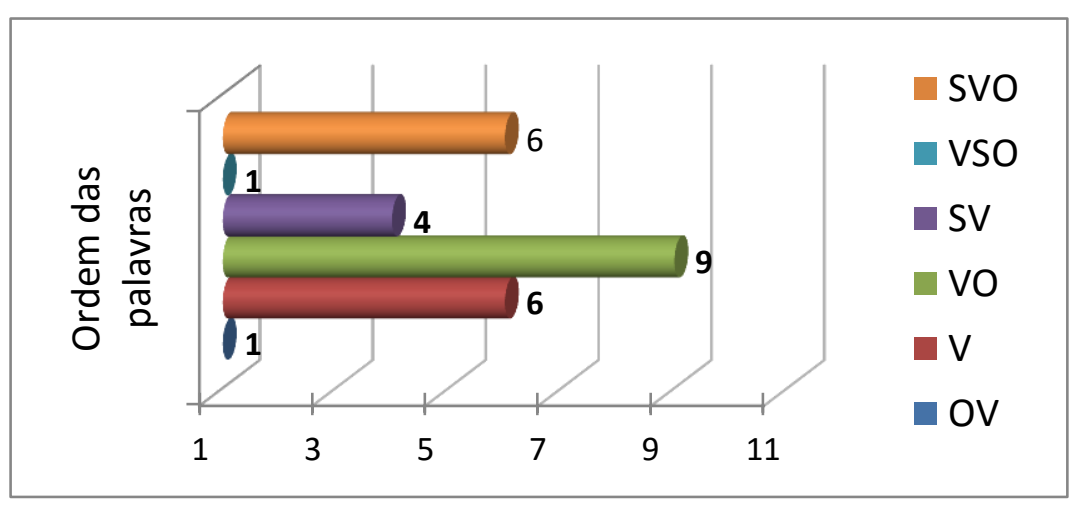


A seguir, apresentamos um exemplo para ilustrar cada ordem encontrada nos dados:

(1) SVO:

$\left(\right.$ conhecer - VTD) $\rightarrow$ LH5(11) = "Eu conhecer amigo." $\rightarrow \mathrm{SVO}_{1}$

(2) VSO:

$\left(\right.$ sentir - VTD) $\rightarrow$ VC4(10) = "Sentir Jonathan feliz." $\rightarrow \mathrm{VSO}_{1}$

(3) SV:

$($ ter - VTD) $\rightarrow$ JA5(11) $=$ "Eu ter nadar." $\rightarrow$ SV/V

(4) VO:

$\left(\right.$ responder - VTD) $\rightarrow \mathrm{LF5}(11)=$ "Responder escreve certo." $\rightarrow \mathrm{S} \phi \mathrm{VO}_{1}$

(5) $\mathrm{V}$ :

(entender - VTD) $\rightarrow$ VC4(10) $=$ "Conversar entender aprender." $\rightarrow \mathrm{V} / \mathrm{V} / \mathrm{V}$

(6) OV:

(entender - VTD) $\rightarrow$ LF5(11) = "Eu escreve Libras entender." $\rightarrow \mathrm{SVO} / \mathrm{S} \mathrm{O}_{1} \mathrm{~V}$

O quadro A2 apresenta verbos transitivos diretos e indiretos (VTDI) com três argumentos.

Quadro A2: Ordem dos termos e VTDI - Participantes de $4^{\circ}$ ao $5^{\circ}$ ano / 10 a 11 anos:

\begin{tabular}{|c|c|c|c|c|c|}
\hline Verbos & ARG. & $\operatorname{VC4}(10)$ & JA5(11) & LF5(11) & LH5(11) \\
\hline $\begin{array}{l}\text { 'ffalar' } \\
\text { (VTDI) }\end{array}$ & 3 & $\mathrm{~S} \phi \mathrm{VO}_{1} \mathrm{O}_{2} \phi$ & $\mathrm{S} \phi \mathrm{VO}_{2} \phi \mathrm{O}_{1}$ & $\mathrm{~S} \phi \mathrm{VO}_{1} \phi \mathrm{O}_{2} \phi$ & $\mathrm{S} \phi \mathrm{VO}_{1} \mathrm{O}_{2} \phi$ \\
\hline $\begin{array}{l}\text { 'avisar' / } \\
\text { 'contar' } \\
\text { (VTDI) }\end{array}$ & 3 & $\mathrm{~S} \phi \mathrm{VO}_{1} \mathrm{O}_{2} \phi$ & $\mathrm{S} \phi \mathrm{VO}_{1} \phi \mathrm{O}_{2} \phi$ & $\mathrm{S} \phi \mathrm{VO}_{1} \mathrm{O}_{2} \phi$ & $\mathrm{S} \phi \mathrm{VO}_{2} \phi \mathrm{O}_{1}$ \\
\hline $\begin{array}{l}\text { 'pagar' } \\
\text { (VTDI) }\end{array}$ & 3 & $\mathrm{~S} \phi \mathrm{VO}_{1} \phi \mathrm{O}_{2} \phi$ & $\mathrm{S} \phi \mathrm{VO}_{1} \mathrm{O}_{2} \phi$ & $\mathrm{SVO}_{1} \phi \mathrm{O}_{2} \phi$ & $\mathrm{O}_{1} \mathrm{O}_{2} \phi \mathrm{S} \phi \mathrm{V}$ \\
\hline $\begin{array}{l}\text { 'convidar’ } \\
\text { (VTDI) }\end{array}$ & 3 & $\mathrm{O}_{1} \mathrm{~S} \phi \mathrm{VO}_{2}$ & $\mathrm{~S} \phi \mathrm{VO}_{2} \phi \mathrm{O}_{1}$ & $\mathrm{~S} \phi \mathrm{VO}_{1} \mathrm{O}_{2} \phi$ & $\mathrm{O}_{1} \mathrm{O}_{2} \phi \mathrm{S} \phi \mathrm{V}$ \\
\hline
\end{tabular}

O quadro A2 mostra a estrutura das sentenças com verbos transitivos diretos e indiretos, isto é, com 3 (três) argumentos. Verificamos a posição dos argumentos na estrutura da oração. Encontramos a maioria dos dados com sujeito nulo [S申]. Nossa hipótese é que, nesses casos, vários participantes se referem à primeira pessoa EU, então, na escrita, não mostram o sujeito. Em outros casos, ocorre troca das ordens, então o primeiro termo é o objeto, como OV, ou os dois objetos ocorrem antes do verbo 
$\mathrm{O}_{1} \mathrm{O}_{2} \mathrm{~V}$. Em LIBRAS, com verbos bitransitivos, como DAR, o argumento tema ocorre muitas vezes antes do verbo.

No quadro A2a, mostramos a quantidade de sentenças em cada tipo de ordem:

Quadro A2a: VTDI e ordem dos termos: total de dados

\begin{tabular}{|r|c|c|}
\hline \multicolumn{2}{|c|}{ ORDEM } & QTS \\
\hline $\mathrm{SVO}_{1} \phi \mathrm{O}_{2} \phi=$ & $\mathrm{SV}$ & 1 \\
\hline $\mathrm{S} \phi \mathrm{VO}_{1} \mathrm{O}_{2}=\mathrm{S} \phi \mathrm{VO}_{2} \phi \mathrm{O}_{1}={\mathrm{S} \phi \mathrm{VO}_{1} \mathrm{O}_{2} \phi=}_{2}$ & $\mathrm{VO}_{1} \mathrm{O}_{2} / \mathrm{VO}_{1}$ & 9 \\
\hline $\mathrm{S} \phi \mathrm{VO}_{1} \phi \mathrm{O}_{2} \phi=$ & $\mathrm{V}$ & 3 \\
\hline $\mathrm{O}_{1} \mathrm{O}_{2} \phi \mathrm{S} \phi \mathrm{V}=$ & $\mathrm{O}_{1} \mathrm{~V}$ & 2 \\
\hline $\mathrm{O}_{1} \mathrm{~S} \phi \mathrm{VO}_{2}=$ & $\mathrm{O}_{1} \mathrm{VO}_{2}$ & 1 \\
\hline
\end{tabular}

Observamos o seguinte resultado com VTDI: a ordem mais usada é $\mathrm{VO}(\mathrm{O})$ $\left(\mathrm{VO}_{1} \mathrm{O}_{2} / \mathrm{VO}_{1}\right)$ (9). Observamos 10 dados na ordem $\mathrm{SV}$ ou $\mathrm{VO}(\mathrm{O})$. Em 3 dados, observamos apenas V. Em 2 dados não ocorre a ordem básica $-\mathrm{O}_{1} \mathrm{~V}$. Em 1 dado, observamos $\mathrm{O}_{1} \mathrm{VO}_{2}$.

O quadro A2b apresenta os mesmos dados quantitativos, em um gráfico diferente.

Quadro A2b: VTDI e ordem dos termos: total de dados

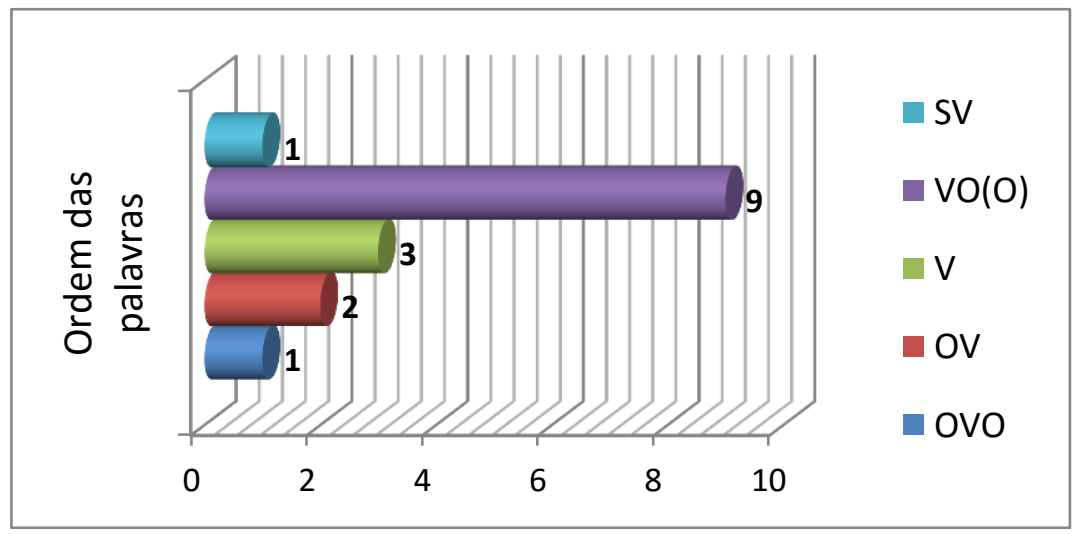

A seguir, apresentamos um exemplo para ilustrar cada ordem encontrada nos dados:

(1) SV:

$\left(\right.$ pagar - VTDI) $\rightarrow$ LF5(11) = "Eu pagar bar." $\rightarrow \mathrm{SVO}_{1} \phi \mathrm{O}_{2} \phi$

(2) $\operatorname{VO}(0)$ :

$($ contar - VTDI $) \rightarrow \mathrm{VC} 4(10)=$ "Contar mãe, pai, irmão." $\rightarrow \mathrm{S} \phi \mathrm{VO}_{1} \mathrm{O}_{2} \phi$ 
(3) $\mathrm{V}$ :

$\left(\right.$ pagar - VTDI) $\rightarrow$ VC4(10) $=$ "Pagar, comprar." $\rightarrow \mathrm{S} \phi \mathrm{VO}_{1} \phi \mathrm{O}_{2} \phi$

(4) OV:

$($ pagar - VTDI $) \rightarrow$ LH5(11) $=$ "Frutas dinheiro pagar certo" $\rightarrow \mathrm{O}_{1} \mathrm{O}_{2} \phi \mathrm{S} \phi \mathrm{V}$

(5) OVO:

$\left(\right.$ convidar - VTDI) $\rightarrow \mathrm{VC} 4(10)=$ "Pessoas convidar para festa." $\rightarrow \mathrm{O}_{1} \mathrm{~S}_{\phi} \mathrm{VO}_{2}$

O quadro A3 apresenta verbos intransitivos, com um argumento.

Quadro A3: Ordem dos termos e VI - Participantes de $4^{\circ}$ ao $5^{\circ}$ ano / 10 a 11 anos:

\begin{tabular}{|c|c|c|c|c|c|}
\hline Verbos & ARG. & VC4(10) & JA5(11) & LF5(11) & LH5(11) \\
\hline $\begin{array}{c}\text { 'nascer' } \\
\text { (VI) }\end{array}$ & $\mathbf{1}$ & $\mathrm{SV}$ & $\mathrm{SV}$ & $\mathrm{SV}$ & $\mathrm{S} \phi \mathrm{V}$ \\
\hline $\begin{array}{c}\text { 'dormir' } \\
\text { (VI) }\end{array}$ & $\mathbf{1}$ & $\mathrm{S} \phi \mathrm{V}$ & $\mathrm{SV}$ & $\mathrm{S} \phi \mathrm{V}$ & $\mathrm{S} \phi \mathrm{V}$ \\
\hline $\begin{array}{c}\text { 'estudar' } \\
\text { (VI)/ VTD }\end{array}$ & $\mathbf{1}$ & $\mathrm{O}_{2}+\mathrm{SV}+\mathrm{O}_{1}$ & $\mathrm{SV}$ & $\mathrm{S} \phi \mathrm{V}$ & $\mathrm{S} \phi \mathrm{V}$ \\
\hline $\begin{array}{c}\text { 'aprender' } \\
\text { (VI)/ VTD }\end{array}$ & $\mathbf{1}$ & $\# \# \#$ & $\mathrm{SV}+\mathrm{O}_{1}$ & $\mathrm{SV}+\mathrm{O}_{1}$ & $\mathrm{~S} \phi \mathrm{V}+\mathrm{O}_{1}$ \\
\hline \multicolumn{7}{|c|}{ Quadro A3: Ordem dos termos e verbos intransitivos } \\
\hline
\end{tabular}

Os verbos intransitivos funcionam como um argumento. No entanto, nos dados, o verbo 'estudar' ocorre como intransitivo, com um argumento (sujeito) e também com dois objetos. O verbo 'aprender' ocorre como intransitivo e como verbo transitivo direto. Encontramos sujeito nulo na estrutura sintática. Assim verificamos a ordem SV, V, OSVO.

No quadro A3a, apresentamos o total de dados em cada tipo ordem encontrada.

Quadro A3a: VI e ordem dos termos: total de dados

\begin{tabular}{|r|c|c|}
\hline \multicolumn{2}{|c|}{ ORDEM } & QTS \\
\hline $\mathrm{O}_{2}+\mathrm{SV}+\mathrm{O}_{1}=\mathrm{SV}+\mathrm{O}_{1}=$ & $\mathrm{SV}$ & 8 \\
\hline $\mathrm{S} \phi \mathrm{V}+\mathrm{O}_{1}=\mathrm{S} \phi \mathrm{V}=$ & $\mathrm{V}$ & 7 \\
\hline
\end{tabular}

O quadro A3b apresenta os mesmos dados quantitativos, em um gráfico diferente. 


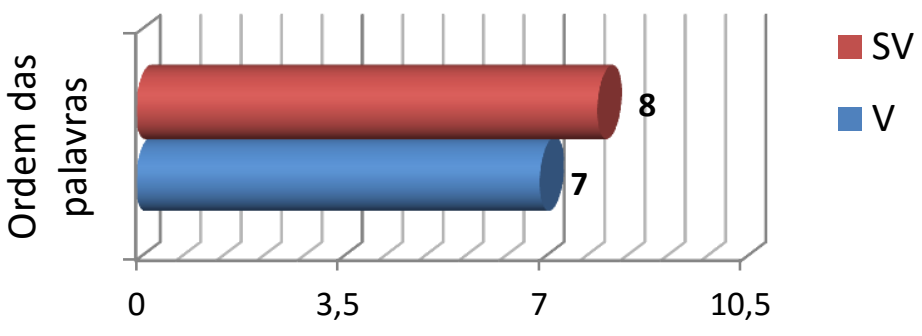

Percebemos que os participantes usam o sujeito nulo com verbos intransitivos [V], e com o verbo realizado com complemento (7). Encontramos também 8 sentenças com sujeito expresso, mas o verbo ocorre com um complemento na ordem [VO] e [OV]. Nossa hipótese é que no caso de sujeito nulo, a referência do sujeito é a primeira pessoa.

A seguir, apresentamos um exemplo para ilustrar cada ordem encontrada nos dados:

(1) SV:

$($ nascer $-\mathrm{VI}) \rightarrow \mathrm{JA5}(11)=$ "Mãe como grávida nascer." $\rightarrow \mathrm{SV} / \mathrm{S} \phi \mathrm{V}^{6}$

(2) $\mathrm{V}$ :

$($ dormir - VI $) \rightarrow \mathrm{VC} 4(10)=$ "Boa noite dormir hora." $\rightarrow \mathrm{S} \phi \mathrm{V}$

O Quadro A4 apresenta o total de sentenças em relação ao tipo de ordem encontrada.

Quadro A4: Total da ordem dos termos

\begin{tabular}{|c|c|c|}
\hline \multirow{7}{*}{ 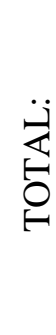 } & SVO & 6 \\
\hline & SV & 13 \\
\hline & VSO & 1 \\
\hline & $\mathrm{V}$ & 16 \\
\hline & $\mathrm{VO}$ & 18 \\
\hline & $\mathrm{OV}$ & 3 \\
\hline & $\mathrm{OVO}$ & 1 \\
\hline
\end{tabular}

Chama a atenção que somente 4 dados apresentam a ordem VSO e OV, que não corresponde à ordem básica. Esse resultado pode ser relacionado ao fato de que a ordem básica na língua de sinais (L1) e também do português (L2) é SVO. Portanto, o uso da

\footnotetext{
${ }^{6} \mathrm{O}$ dado admite duas interpretações: Mãe (ficou) grávida e (eu) nasci - e nesse caso, o sujeito é nulo. Ou então: Mãe grávida nascer (=Mãe me pariu) - nesse caso o sujeito é 'mãe'. Agradecemos à Profa. Rozana Naves por destacar o dado no contexto da análise.
} 
ordem que não corresponde à ordem básica do português é uma opção marcada por ênfase em relação ao termo deslocado. Em 16 dados observamos uso apenas do verbo. Isso significa que o participante usa o sujeito nulo e objeto nulo. Esse resultado pode ser relacionado à interferência da L1, uma vez que a língua de sinais usa pronomes por um sistema de apontação (conforme mostramos no capítulo 3), e esse sistema não tem um correspondente direto no português (L1). Nossa hipótese é que o aluno não estabelece uma relação direta entre a apontação na LIBRAS (L1) e o uso do pronome em português (escrito) (L2). Em 18 dados é realizada a estrutura VO, ou seja, o sujeito é nulo. Concluímos que o argumento interno é muito importante para o significado da sentença, e por isso não pode ser retirado.

\section{Grupo B: $8^{\circ}$ e $9^{\circ}$ ano}

A seguir, mostramos o quadro B1, que se refere aos dados produzidos pelos participantes do $8^{\circ}$ e $9^{\circ}$ ano. A atividade verifica o uso de verbos transitivos diretos, com 2 argumentos.

Quadro B1 - Ordem dos termos e VTD - Participantes do $8^{\circ}$ ao $9^{\circ}$ ano (14 a 19 anos).

\begin{tabular}{|c|c|c|c|c|c|c|c|c|}
\hline Verbos & ARG. & IS8(18) & MM8(16) & RA8(15) & RS8(20) & TR8(14) & BH9(19) & EL9(19) \\
\hline $\begin{array}{l}\text { 'entender' } \\
\text { (VTD) }\end{array}$ & 2 & $\mathrm{~S} \phi \mathrm{VO}_{1} \phi+\mathrm{O}_{2}$ & $\mathrm{~S} \phi \mathrm{VO}_{1}$ & $\mathrm{SO}_{1} \mathrm{~V}$ & $\mathrm{VSO}_{1} \phi$ & $\mathrm{SVO}_{1}$ & $\mathrm{~S} \phi \mathrm{VO}_{1} \phi$ & $\mathrm{SVO}_{1} \phi$ \\
\hline $\begin{array}{c}\text { 'ter' } \\
\text { (VTD) }\end{array}$ & 2 & $\mathrm{VSO}_{1}+\mathrm{O}_{2}$ & $\mathrm{~S} \phi \mathrm{VO}_{1}$ & $\mathrm{SVO}_{1}$ & $\mathrm{~S} \phi \mathrm{VO}_{1}$ & $\mathrm{~S} \phi \mathrm{VO}_{1}$ & $\mathrm{~S} \phi \mathrm{VO}_{1}$ & $\mathrm{SVO}_{1}$ \\
\hline $\begin{array}{l}\text { 'estudar' } \\
\text { (VTD/VI) }\end{array}$ & 2 & $\mathrm{~S} \phi \mathrm{VO}_{1} \phi+\mathrm{O}_{2}$ & $\mathrm{~S} \phi \mathrm{VO}_{1} \phi$ & $\mathrm{SVO}_{1} \phi$ & $\mathrm{SVO}_{1}$ & $\mathrm{SVO}_{1} \phi$ & $\mathrm{S} \phi \mathrm{VO}_{1} \phi$ & \#\#\# \\
\hline $\begin{array}{l}\text { 'aprender' } \\
\text { (VTD/VI) }\end{array}$ & 2 & \#\#\# & $\mathrm{S} \phi \mathrm{VO}_{1}$ & $\mathrm{SVO}_{1} \phi$ & $\mathrm{S} \phi \mathrm{VO}_{1}$ & $\mathrm{~S} \phi \mathrm{VO}_{1}$ & $\mathrm{~S} \phi \mathrm{VO}_{1}$ & $\mathrm{~S} \phi \mathrm{VO}_{1} \phi$ \\
\hline $\begin{array}{l}\text { 'sentir’ } \\
\text { (VTD) }\end{array}$ & 2 & $\mathrm{~S} \phi \mathrm{VO}_{1}$ & $\mathrm{~S} \phi \mathrm{VO}_{1}$ & $\mathrm{SVO}_{1}$ & $\mathrm{~S} \phi \mathrm{VO}_{1}$ & $\mathrm{~S} \phi \mathrm{VO}_{1}$ & $\mathrm{~S} \phi \mathrm{VO}_{1}$ & $\mathrm{SVO}_{1}$ \\
\hline $\begin{array}{c}\text { 'responder' } \\
\text { (VTD) }\end{array}$ & 2 & $\mathrm{~S} \phi \mathrm{VO}_{1}$ & $\mathrm{~S} \phi \mathrm{VO}_{1} \phi$ & $\mathrm{SO}_{1} \mathrm{~V}$ & $\mathrm{VSO}_{1} \phi$ & $\mathrm{S} \phi \mathrm{VO}_{1}$ & $\mathrm{~S} \phi \mathrm{VO}_{1}$ & $\mathrm{SVO}_{1} \phi$ \\
\hline $\begin{array}{l}\text { ‘conhecer’ } \\
\text { (VTD) }\end{array}$ & 2 & $\mathrm{~S} \phi \mathrm{VO}_{1}$ & $\mathrm{~S} \phi \mathrm{VO}_{1}$ & $\mathrm{SO}_{1} \mathrm{~V}$ & $\mathrm{~S} \phi \mathrm{VO}_{1}$ & $\mathrm{SVO}_{1}$ & $\mathrm{~S} \phi \mathrm{VO}_{1}$ & $\mathrm{SVO}_{1}$ \\
\hline
\end{tabular}

No quadro acima, verificamos o uso dos VTD, selecionam dois argumentos. Podemos ver que os participantes de $8^{\circ}$ ao $9^{\circ}$ conseguem construir sua compreensão de português como L2. O objetivo é ver como funcionam esses verbos e os seus argumentos na posição do sujeito e objeto nos dados da interlíngua. Observamos os dados examinados em todas as ordens, na escrita feita pelos participantes. 
O quadro B1a mostra a quantificação das ordens encontradas.

\begin{tabular}{|c|c|c|}
\hline \multicolumn{2}{|l|}{ ORDEM } & QTS \\
\hline $\mathrm{SVO}_{1}=$ & SVO & 8 \\
\hline $\mathrm{SVO}_{1} \phi=$ & SV & 5 \\
\hline $\mathrm{S} \phi \mathrm{VO}_{1}=$ & $\mathrm{VO}$ & 21 \\
\hline $\mathrm{S} \phi \mathrm{VO}_{1} \phi+\mathrm{O}_{2}=\mathrm{S} \phi \mathrm{VO}_{1} \phi=$ & $\mathrm{V}$ & 7 \\
\hline $\mathrm{VSO}_{1}+\mathrm{O}_{2}=$ & VSO & 1 \\
\hline $\mathrm{SO}_{1} \mathrm{~V}=$ & SOV & 3 \\
\hline $\mathrm{VSO}_{1} \phi=$ & VS & 2 \\
\hline
\end{tabular}

Observamos, em primeiro lugar, que a ordem VO com sujeito nulo aparece em maior quantidade (21), em segundo lugar, aparece a ordem SVO (8). Em seguida, encontramos os casos em que aparece somente o verbo. Em 5 dados, encontramos a ordem SV. Em 6 dados, a ordem dos termos não é a ordem básica SVO (7). Em 3 casos, o sujeito vem após o verbo, e o objeto vem antes do verbo. Observamos que as ordens SVO, SV e VO, que correspondem à ordem básica, são um total de 34. Concluímos que a ordem preferencial nos dados é a mesma da LIBRAS (L1) e do português (L2). Esse resultado é também encontrado nos dados de participantes com 10 e 11 anos do $4^{\circ}$ e $5^{\circ}$ ano.

O quadro B1b apresenta os mesmos dados quantitativos, em um gráfico diferente.

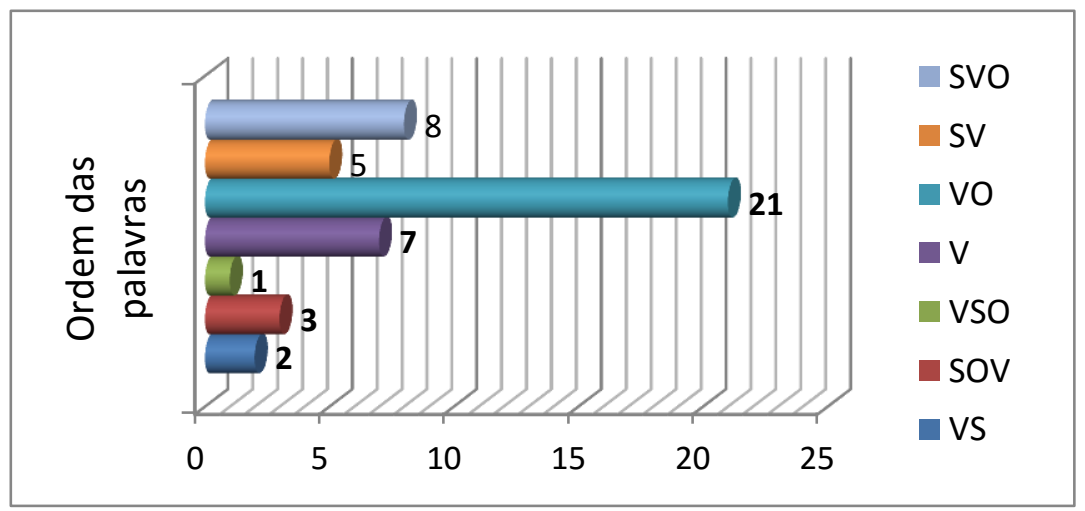

A seguir, apresentamos um exemplo para ilustrar cada ordem encontrada nos dados:

(1) SVO:

$($ conhecer - VTD $) \rightarrow$ TR8(14) = "Escola aluno ver conhece sinais aluno próprio surdo." $\rightarrow \mathrm{SVO}_{1}$ 
(2) SV:

(estudar - VTD) $\rightarrow$ TR8(14) = "Eu estudar saber aprender já mas cada aluno escreva prova." $\rightarrow \mathrm{SVO}_{1} \phi$

(3) VO:

$\left(\right.$ sentir - VTD) $\rightarrow \mathrm{RS} 8(20)=$ "Sentir amores quero abraço." $\rightarrow \mathrm{S} \phi \mathrm{VO}_{1}$

(4) $\mathrm{V}$ :

$\left(\right.$ responder - VTD) $\rightarrow \mathrm{MM} 8(16)=$ "Responda escreve letra." $\rightarrow \mathrm{S} \phi \mathrm{VO}_{1} \phi$

(5) VSO:

$\left(\right.$ ter - VTD) $\rightarrow$ IS8(18) $=$ "Tem eu família e dento(dentro) com casa" $\rightarrow \mathrm{VSO}_{1}+\mathrm{O}_{2}$

(6) SOV:

(responder - VTD) $\rightarrow$ RA8(15) = "Pessoas grupo whatsapp Libras respondar."

$$
\rightarrow \mathrm{SO}_{1} \mathrm{~V}
$$

(7) VS:

$($ entender - VTD $) \rightarrow$ RS8(20) $=$ "Entendeu surdos amigos" $\rightarrow \mathrm{VSO}_{1} \phi$

O Quadro B2 mostra o resultado produzido pelos participantes do $8^{\circ}$ e $9^{\circ}$ ano. A atividade verifica o uso de verbos transitivos diretos e indiretos, com 3 (três) argumentos.

Quadro B2: Ordem dos termos e VTDI - Participantes do $8^{\circ}$ e $9^{\circ}$ ano

\begin{tabular}{|c|c|c|c|c|c|c|}
\hline Verbos & ARG. & IS8(18) & MM8(16) & RA8(15) & RS8(20) & TR8(14) \\
\hline $\begin{array}{c}\text { 'falar' } \\
\text { (VTDI) }\end{array}$ & 3 & $\mathrm{~S} \phi \mathrm{VO}_{1} \phi \mathrm{O}_{2} \phi$ & $\mathrm{S} \phi \mathrm{VO}_{1} \mathrm{O}_{2} \phi$ & $\mathrm{SVO}_{1} \mathrm{O}_{2} \phi$ & $\mathrm{S} \phi \mathrm{VO}_{1} \mathrm{O}_{2} \phi$ & $\mathrm{SVO}_{1} \phi \mathrm{O}_{2} \phi$ \\
\hline $\begin{array}{l}\text { 'avisar' } \\
\text { (VTDI) }\end{array}$ & 3 & $\mathrm{~S} \phi \mathrm{VO}_{1} \mathrm{O}_{2} \phi$ & $\mathrm{S} \phi \mathrm{VO}_{1} \phi \mathrm{O}_{2} \phi$ & $\mathrm{SVO}_{1} \mathrm{O}_{2} \phi$ & $\mathrm{S} \phi \mathrm{VO}_{1} \mathrm{O}_{2} \phi$ & $\mathrm{S} \phi \mathrm{VO}_{1} \mathrm{O}_{2} \phi$ \\
\hline $\begin{array}{l}\text { 'estudar' } \\
\text { (VTDI) }\end{array}$ & 3 & $\mathrm{~S} \phi \mathrm{VO}_{1} \phi \mathrm{O}_{2}$ & $\mathrm{~S} \phi \mathrm{VO}_{1} \phi \mathrm{O}_{2} \phi$ & $\mathrm{SVO}_{1} \phi \mathrm{O}_{2} \phi$ & $\mathrm{SVO}_{1} \mathrm{O}_{2} \phi$ & $\mathrm{SVO}_{1} \phi \mathrm{O}_{2} \phi$ \\
\hline $\begin{array}{l}\text { 'pagar' } \\
\text { (VTDI) }\end{array}$ & 3 & $\mathrm{~S} \phi \mathrm{VO}_{2} \phi \mathrm{O}_{1}$ & $\mathrm{~S} \phi \mathrm{VO}_{1} \mathrm{O}_{2} \phi$ & $\mathrm{SVO}_{1} \mathrm{O}_{2} \phi$ & $\mathrm{S} \phi \mathrm{VO}_{1} \mathrm{O}_{2} \phi$ & $\mathrm{SVO}_{1} \mathrm{O}_{2} \phi$ \\
\hline $\begin{array}{c}\text { 'convidar' } \\
\text { (VTDI) }\end{array}$ & 3 & $\mathrm{~S} \phi \mathrm{VO}_{2} \phi \mathrm{O}_{1}$ & \#\#\# & $\mathrm{S} \phi \mathrm{VO}_{1} \phi \mathrm{O}_{2} \phi$ & $\mathrm{S} \phi \mathrm{VO}_{1} \phi \mathrm{O}_{2} \phi$ & $\mathrm{SVO}_{1} \phi \mathrm{O}_{2} \phi$ \\
\hline
\end{tabular}

Quadro B2: Ordem dos termos e verbos transitivos diretos e indiretos

\begin{tabular}{|c|c|c|c|}
\hline Verbos & ARG. & BH9(19) & EL9(19) \\
\hline $\begin{array}{l}\text { 'falar' } \\
\text { (VTDI) }\end{array}$ & 3 & $\mathrm{~S} \phi \mathrm{VO}_{1} \mathrm{O}_{2} \phi$ & $\mathrm{S} \phi \mathrm{VO}_{1} \mathrm{O}_{2} \phi$ \\
\hline $\begin{array}{l}\text { 'avisar' } \\
\text { (VTDI) }\end{array}$ & 3 & $\mathrm{~S} \phi \mathrm{VO}_{1} \mathrm{O}_{2} \phi$ & $\mathrm{SVO}_{1} \phi \mathrm{O}_{2} \phi$ \\
\hline $\begin{array}{l}\text { 'estudar' } \\
\text { (VTDI) }\end{array}$ & 3 & $\mathrm{~S} \phi \mathrm{VO}_{1} \phi \mathrm{O}_{2} \phi$ & \#\#\# \\
\hline $\begin{array}{l}\text { 'pagar' } \\
\text { (VTDI) }\end{array}$ & 3 & $\mathrm{~S} \phi \mathrm{VO}_{1} \mathrm{O}_{2} \phi$ & $\mathrm{SVO}_{1} \mathrm{O}_{2} \phi$ \\
\hline $\begin{array}{l}\text { 'convidar' } \\
\text { (VTDI) }\end{array}$ & 3 & $\mathrm{~S} \phi \mathrm{VO}_{1} \phi \mathrm{O}_{2} \phi$ & $\mathrm{SVO}_{1} \phi \mathrm{O}_{2} \phi$ \\
\hline
\end{tabular}

Quadro B2: Ordem dos termos e verbos transitivos diretos e indiretos 
Mostramos o quadro B2, com os participantes de $8^{\circ}$ ao $9^{\circ}$. Os VTDI expressam a realização do argumento externo e dos argumentos internos, ou seja, o objeto direto (sem preposição) e o objeto indireto (com preposição).

No quadro B2a, apresentamos a quantificação das ordens encontradas:

\begin{tabular}{|r|c|c|}
\hline \multicolumn{2}{|c|}{ ORDEM } & QTS \\
\hline $\mathrm{SVO}_{1} \mathrm{O}_{2} \phi=\mathrm{SVO}_{1} \phi \mathrm{O}_{2}=$ & $\mathrm{SVO}$ & 7 \\
\hline $\mathrm{SVO}_{1} \phi \mathrm{O}_{2} \phi=$ & $\mathrm{SV}$ & 6 \\
\hline $\mathrm{S} \phi \mathrm{VO}_{1} \mathrm{O}_{2} \phi=\mathrm{S} \phi \mathrm{VO}_{1} \phi \mathrm{O}_{2}=\mathrm{S} \phi \mathrm{VO}_{2} \phi \mathrm{O}_{1}=$ & $\mathrm{VO}$ & 13 \\
\hline $\mathrm{S} \phi \mathrm{VO}_{1} \phi \mathrm{O}_{2} \phi=$ & $\mathrm{V}$ & 7 \\
\hline
\end{tabular}

Encontramos que a posição do sujeito ficou vazia em 20 dados, portanto os alunos não marcaram essa posição com sintagmas nominais (SN) ou com os pronomes para dar sentido para a estrutura sintática. Verificamos também que, em todos os dados desses VTDI, as maiores quantidades são de [VO] (13) e em segundo lugar, o empate [SVO] e [V], com 7 dados cada um. Não foi observado nenhum caso de mudança na ordem básica. Não foi observado nenhum caso com o objeto direto e o objeto indireto realizado como SN. Nos casos de ordem SVO e VO, somente um objeto foi realizado, e geralmente era o alvo. Encontramos 2 (dois) dados em que o tema é realizado como oração.

O quadro B2b apresenta os mesmos dados quantitativos, em um gráfico diferente.

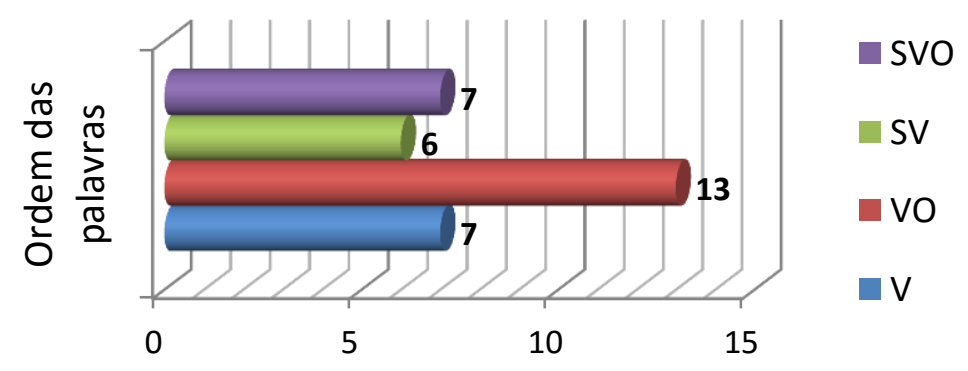

A seguir, apresentamos um exemplo para ilustrar cada ordem encontrada nos dados:

(1) SVO:

(pagar - VTDI) $\rightarrow$ EL9(19) = "Eu vai pagar alimentação." $\rightarrow \mathrm{SVO}_{1} \mathrm{O}_{2} \phi$ 
(2) SV:

$($ convidar - VTDI $) \rightarrow$ TR8(14) $=$ "Pessoas convidar foi gostoso comida." $\rightarrow$ $\mathrm{SVO}_{1} \phi \mathrm{O}_{2} \phi$

(3) $\mathrm{VO}[\mathrm{O}]$ :

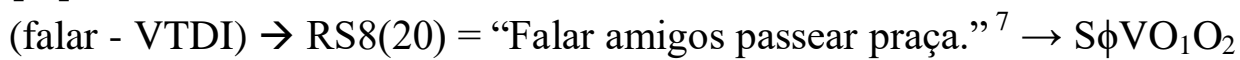

(4) $\mathrm{V}$ :

$($ convidar - VTDI $) \rightarrow \mathrm{BH} 9(19)=$ "Convidar poder casa." $\rightarrow \mathrm{S} \phi \mathrm{VO}_{1} \phi \mathrm{O}_{2} \phi$

O Quadro B3 mostra o resultado produzido pelos participantes do $8^{\circ}$ e $9^{\circ}$ ano, com verbos intransitivos.

Quadro B3: Ordem dos termos e VI - Participantes do $8^{\circ}$ e $9^{\circ}$ ano

\begin{tabular}{|c|c|c|c|c|c|c|c|c|}
\hline Verbos & ARG. & IS8(18) & MM8(16) & RA8(15) & RS8(20) & TR8(14) & BH9(19) & EL9(19) \\
\hline $\begin{array}{c}\text { 'nascer' } \\
\text { (VI) }\end{array}$ & $\mathbf{1}$ & $\mathrm{SV}$ & $\mathrm{S} \phi \mathrm{V}$ & $\mathrm{SV}$ & $\mathrm{S} \phi \mathrm{V}+\mathrm{O}$ & $\mathrm{SV}$ & $\# \#$ & $\mathrm{SV}$ \\
\hline $\begin{array}{c}\text { 'dormir' } \\
\text { (VI) }\end{array}$ & $\mathbf{1}$ & $\# \# \#$ & $\mathrm{~S} \phi \mathrm{V}$ & $\mathrm{S} \phi \mathrm{V}$ & $\mathrm{S} \phi \mathrm{V}$ & $\mathrm{S} \phi \mathrm{V}$ & $\mathrm{S} \phi \mathrm{V}+\mathrm{O}$ & $\mathrm{S} \phi \mathrm{V}$ \\
\hline $\begin{array}{c}\text { 'estudar' } \\
\text { (VI) }\end{array}$ & $\mathbf{1}$ & $\mathrm{S} \phi \mathrm{V}$ & $\mathrm{S} \phi \mathrm{V}$ & $\mathrm{SV}$ & $\mathrm{SV}+\mathrm{O}$ & $\mathrm{SV}$ & $\mathrm{S} \phi \mathrm{V}$ & $\# \# \#$ \\
\hline $\begin{array}{c}\text { 'aprender' } \\
\text { (VI) }\end{array}$ & $\mathbf{1}$ & $\mathrm{S} \phi \mathrm{V}$ & $\mathrm{S} \phi \mathrm{V}+\mathrm{O}$ & $\mathrm{SV}$ & $\mathrm{S} \phi \mathrm{V}+\mathrm{O}$ & $\mathrm{S} \phi \mathrm{V}+\mathrm{O}$ & $\mathrm{S} \phi \mathrm{V}$ & $\mathrm{S} \phi \mathrm{V}$ \\
\hline
\end{tabular}

Encontramos acima esse quadro que apresenta os VI. Observamos que o lugar da posição do sujeito é preenchido por um sintagma nominal ou é usado o sujeito nulo. Encontramos também nos dados usados pelos participantes, a ordem $\mathrm{V}$ sem os argumentos. Por isso perguntamos: por que podem elaborar a frase com a ausência da posição do sujeito? Refletimos que uma hipótese é que o surdo não adquiriu o conhecimento do pronome em português (escrito) (L2), por falta de ensinamento na escola - nos termos da gramática gerativa, por falta de input linguístico.

Mostramos abaixo a quantificação das ordens das palavras encontradas.

Quadro B3a: Ordem dos termos e VI ( $8^{\circ}$ e $9^{\circ}$ ano $)$

\footnotetext{
${ }^{7}$ Nesse dado, podemos analisar como objeto do verbo 'falar' a oração 'passear na praça' $\rightarrow$ Ele falou para os amigos para passear na praça/Ele falou para os amigos: (vamos) passear na praça? Da mesma forma, podemos analisar o objeto do verbo 'avisar': '(ele) avisou para os amigos conversar na rua'.
} 


\begin{tabular}{|r|c|c|}
\hline \multicolumn{2}{|c|}{ ORDEM } & QTS \\
\hline $\mathrm{SV}+\mathrm{O}=$ & $\mathrm{SV}$ & 8 \\
\hline $\mathrm{S} \phi \mathrm{V}+\mathrm{O}=\mathrm{S} \phi \mathrm{V}=$ & $\mathrm{V}$ & 17 \\
\hline
\end{tabular}

Encontramos o sujeito nulo em 17 sentenças, e o sujeito preenchido pelo sintagma nominal (SN) em 8 sentenças. Destacamos também um caso em que a oração com verbo intransitivo aparece com um objeto.

O quadro B3b apresenta os mesmos dados quantitativos, em um gráfico diferente:

Quadro B3b: Ordem dos termos e VI ( $8^{\circ}$ e $9^{\circ}$ ano $)$

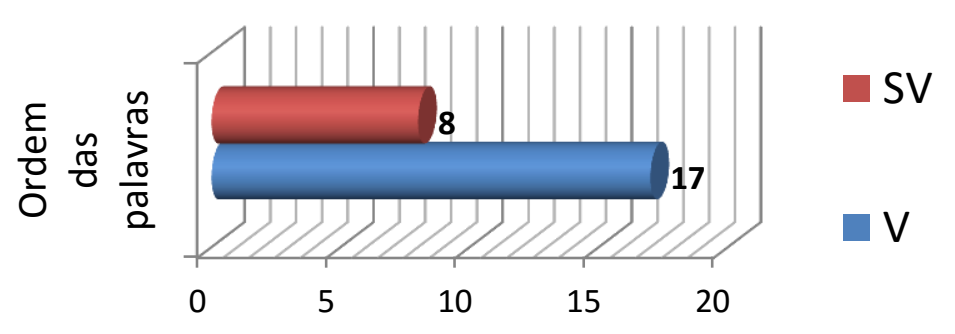

A seguir, apresentamos um exemplo para ilustrar cada ordem encontrada nos dados:

(1) SV:

$($ nascer - VI) $\rightarrow$ RA8(15) = "Mulher vontade quero nasceu." $\rightarrow \mathrm{SV}$

(2) $\mathrm{V}$ :

(aprender - VI) $\rightarrow \mathrm{BH} 9(19)=$ "Aprender mais presente mesma." $\rightarrow \mathrm{S} \phi \mathrm{V}$

Notamos, a seguir, para os participantes de $8^{\circ}$ ao $9^{\circ}$ ano do ensino fundamental, os números totais da ordem das palavras que foram analisados. Encontramos que o resultado [VO] é maior (34), que em segundo lugar, é [V] (31), e em terceiro lugar é [SV] (19), e depois, por último, [SVO] (15). Quando analisamos esse resultado já verificamos que os alunos estão melhorando sua aprendizagem na escrita de português em relação aos outros participantes de $4^{\circ}$ ao $5^{\circ}$. Encontramos somente 6 sentenças que não utilizam a ordem básica. Essas sentenças ocorrem na ordem VSO e VS, mas não encontramos ordem $\mathrm{OV}(\mathrm{S})$. 
Quadro A4: Total da ordem dos termos

\begin{tabular}{|c|c|c|}
\hline \multirow{7}{*}{ 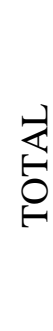 } & SVO & 15 \\
\hline & SV & 19 \\
\hline & SOV & 3 \\
\hline & V & 31 \\
\hline & $\mathrm{VO}$ & 34 \\
\hline & VSO & 1 \\
\hline & VS & 2 \\
\hline
\end{tabular}

O quadro A+B apresenta a quantificação de todos os dados coletados nesta pesquisa. Verificamos que o resultado geral na ordem das palavras ficou em primeiro a ordem [VO] (34). Em seguida, aparece à sentença com [V] (31), e depois a ordem [SV] (19), e a ordem [SVO] (15). A quantificação total não permite distinguir os tipos de verbo. No entanto, podemos concluir que a preferência pela ordem VO indica que a relação entre $\mathrm{V}$ e seu objeto é muito importante para o significado da sentença, pois o objeto (direto) é selecionado pelo verbo. Como o verbo tem o mesmo significado, a relação entre o verbo e o objeto é a mesma em português e em LIBRAS. Em relação ao sujeito, é diferente. Nossa hipótese é que o aluno pode construir a sentença com o sujeito nulo e ter como referente à $1^{\mathrm{a}}$ pessoa (EU). O uso da primeira pessoa como sujeito nulo é possível com vários sinais da LIBRAS, com verbos de concordância (ver Capítulo 2) e também com outros verbos (se o sinal é realizado no corpo do falante). Nesse caso, podemos dizer que é uma interferência da L1. Em orações na ordem [SV] e [SVO] já estão marcados pelo sujeito, e pelo objeto. Isso mostra que os alunos conseguiram construir a estrutura da oração inserindo a posição de sujeito. Essa posição é preenchida por um SN ou pelos pronomes pessoais adquiridos na segunda língua na modalidade escrita em língua portuguesa.

Finalmente, destacamos que é muito pequeno o número de sentenças que não segue a ordem básica (11), em relação ao número de sentenças na ordem básica (99). Conforme mencionado, esse resultado confirma que o aluno utiliza a ordem básica da LIBRAS, que é a mesma a ordem básica em português. Sabemos que as sentenças em LIBRAS podem ocorrer em outras ordens, com topicalização, com duplicação de foco, mas essa questão não foi testada, porque a atividade pedia que o aluno escrevesse uma frase com o verbo. Nesse caso, a tendência é que a sentença tem foco largo, ou seja, elas respondem a uma pergunta do tipo: $\mathrm{O}$ que aconteceu? 
Quadro A+B: Ordem dos termos e tipos de verbo

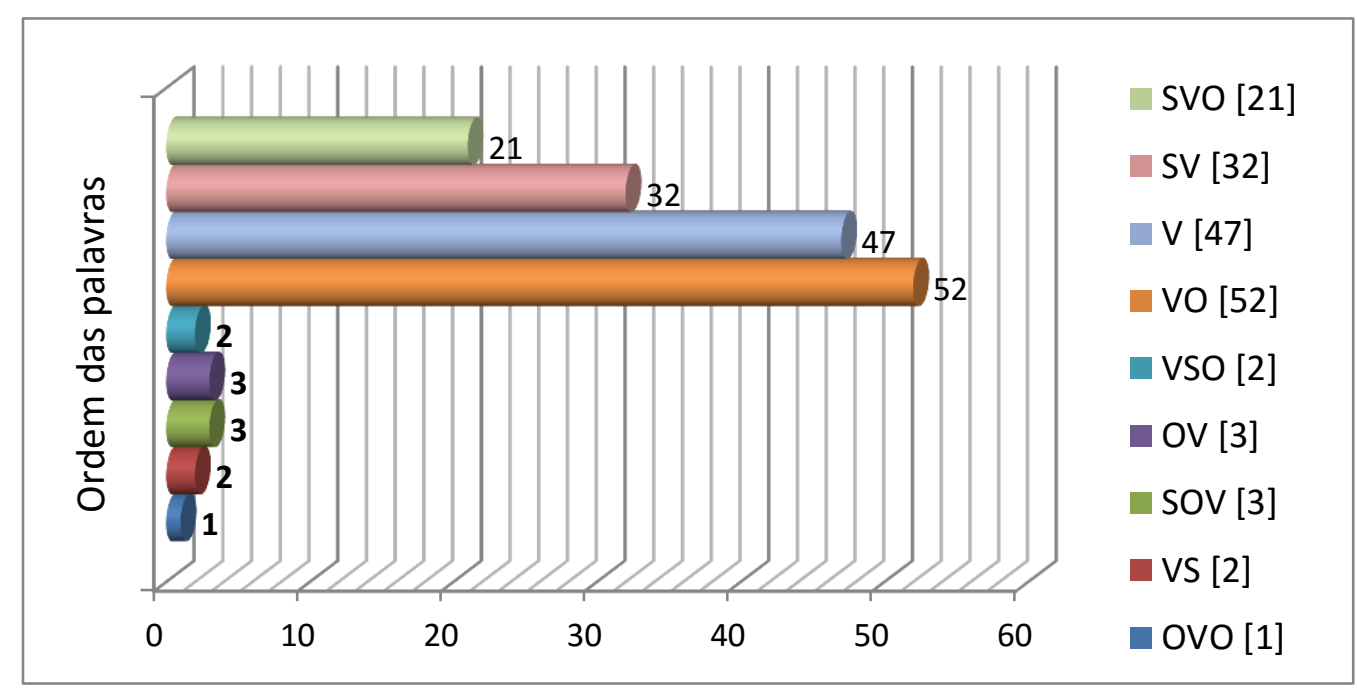

\subsubsection{Atividade 2: ordem dos termos e preenchimento da posição de sujeito e de complemento em narrativas}

$\mathrm{Na}$ atividade 2, analisamos a ordem dos termos e o preenchimento da posição de sujeito e de complemento em narrativas. A atividade é proposta para demonstrar a posição dos argumentos. Nessa atividade, o aluno deve criar um texto de acordo com as cenas em sequência de uma estória em quadrinhos (ver anexo 2).

Para tanto, inicialmente, pedimos aos participantes para expressar suas ideias sobre as imagens fazendo uso de LIBRAS. Após a discussão em LIBRAS, os participantes expressaram as ideias por escrito em português.

A análise dos dados será muito importante para investigar a expressão sintática da estrutura argumental, isto é, para verificar como marcaram a posição do sujeito e do objeto, considerando também a retomada a anafórica por meio de pronomes. Examinamos os dados dos participantes de $4^{\circ}$ ao $5^{\circ}$ e $8^{\circ}$ ao $9^{\circ}$ ano do ensino fundamental. Como na seção anterior, o $4^{\circ}$ e o $5^{\circ}$ ano ficaram no Grupo A, e o $8^{\circ}$ e o $9^{\circ}$ ano ficaram no Grupo B.

A seguir, escolhemos alguns participantes para mostrar as análises que exemplificam o resultado. Veja as legendas para analisar os dados:

$$
\begin{aligned}
X & =\text { ARGUMENTO PRESENTE } \\
\varnothing & =\text { ARGUMENTO NULO }
\end{aligned}
$$




$$
\begin{aligned}
& ?=D U ́ V I D A \\
& --\quad=A U S E N T E
\end{aligned}
$$

\section{Grupo A: $4^{\circ}$ e $5^{\circ}$ ano}

Selecionamos o participante VC4(10), e verificamos os verbos que aparecem no texto, que podem ser classificados como verbos transitivos diretos (VTD) e transitivos diretos e indiretos (VTDI) e intransitivos (VI). Vejamos o quadro com frases retiradas da produção de textos do participante VC4(10):

Quadro A1a: Verbo transitivo direto (VTD)

\begin{tabular}{|l|c|c|c|}
\hline \multicolumn{1}{|c|}{ FRASES RETIRADAS DO TEXTO } & $\begin{array}{c}\text { QTS } \\
\text { ARGUMENTOS }\end{array}$ & EXTERNO & INTERNO \\
\hline Margarida pegando furta (frutas) & 2 & $\mathrm{X}$ & $\mathrm{X}$ \\
\hline Cebolinha jogarndo [água] & 2 & $\mathrm{X}$ & --- \\
\hline [Ele] plantar floroes (flores), milho. & 2 & $\varnothing$ & $\mathrm{X}$ \\
\hline Cebolinha pegou goiaba & 2 & $\mathrm{X}$ & $\mathrm{X}$ \\
\hline Magali ajudarndo [Cebolinha] & 2 & $\mathrm{X}$ & $\varnothing$ \\
\hline Cascão colher [frutas] & 2 & $\mathrm{X}$ & $\varnothing$ \\
\hline Mônica fazendo anotar [=anotação] & 2 [?] & $\mathrm{X}$ & $\varnothing$ \\
\hline
\end{tabular}

No Quadro A1a, observamos que, na maioria dos dados, o aluno preenche a posição de sujeito com o argumento externo para introduzir os personagens da narrativa. Em um dado, ocorre o sujeito nulo [Ele], que pode ser recuperado pelo antecedente [Cebolinha]. Em relação ao argumento interno, temos três casos de preenchimento da posição de objeto (direto): 'pegando furta', 'plantar floroes, milho', 'pegou goiaba'. Observamos um caso em que é possível recuperar o argumento externo (retomada anafórica): 'Magali ajudando [Cebolinha]', e dois casos em que o argumento interno é nulo e pode ser recuperado pelo significado do verbo ou com o apoio da imagem: ‘jogarndo [água]'; 'Cascão colher [frutas]'.

Quadro A1b: Verbo transitivo direito e indireto (VTDI)

\begin{tabular}{|c|c|c|c|c|}
\hline FRASES RETIRADAS DO TEXTO & $\begin{array}{c}\text { QTS } \\
\text { ARGUMENTOS }\end{array}$ & \multicolumn{2}{|c|}{ EXTERNO } & \multicolumn{2}{|c|}{ INTERNO } \\
\hline [Cebolinha] [colocar] [goiaba] [na] cesta & 3 & $\varnothing$ & $\varnothing$ & $X$ \\
\hline
\end{tabular}

No Quadro A1b, um dado ocorre com o sujeito nulo, que pode ser recuperado pelo antecedente. Pela presença do argumento 'cesta', e com o apoio da imagem, supomos 
que o verbo é 'colocar' (VTDI). Na posição do complemento desse dado ocorre o objeto direto nulo, que pode ser recuperado pelo antecedente [goiaba], e o objeto indireto está presente, e realizado pelo item lexical 'cesta', que indica o argumento interpretado como o alvo da transferência, ou o lugar.

Quadro A1c - Verbo intransitivo

\begin{tabular}{|l|c|c|c|}
\hline \multicolumn{1}{|c|}{ FRASES RETIRADAS DO TEXTO } & $\begin{array}{c}\text { QTS } \\
\text { ARGUMENTOS }\end{array}$ & EXTERNO & INTERNO \\
\hline Cascão trator arar & 1 & $\mathrm{X}$ & \\
\hline Caminhão viajar & 1 & $\mathrm{X}$ & \\
\hline Mónica fazendo anotar (=anotando) & 1 [?] & $\varnothing$ & \\
\hline Caminhão saiu & 1 & & $\mathrm{X}$ \\
\hline
\end{tabular}

No Quadro A1c, mostramos que o participante surdo consegue preencher a posição do sujeito com argumento externo quando o verbo é intransitivo. Um dado ocorre com o sujeito nulo, pois o argumento externo é recuperado [Cascão trator arar. [Ele] caminhão viajar]. Em um dado ficamos em dúvida, pois não sabemos se colocamos 'anotar' como um argumento do verbo 'fazendo' [fazendo anotar (=anotação)], ou se consideramos como uma estrutura com dois verbos [fazendo anotar (=anotando)], para dar o sentido da estrutura sintática. O último dado permite duas análises: o argumento 'caminhão' preenche a posição de sujeito do verbo 'sair' [O caminhão saiu], ou o sujeito do verbo 'sair' é nulo, com o antecedente Cascão, e o sintagma nominal 'caminhão' é um adjunto adverbial [=(ele) saiu (de) caminhão].

Nos quadros A2a, abaixo, apresentamos a quantificação do preenchimento da estrutura argumental de verbos VTD/ VTDI encontrados nas narrativas:

Quadro A2a - Preenchimento da estrutura argumental VTD/ VTDI

- Participantes de $4^{o}$ ao $5^{\circ}$

\begin{tabular}{|c|c|c|c|c|c|c|c|c|}
\hline & & $\begin{array}{l}\text { VTD/ } \\
\text { VTDI }\end{array}$ & $\begin{array}{c}\text { Argu } \\
\text { Pre } \\
\end{array}$ & $\begin{array}{l}\text { ento } \\
\text { nte }\end{array}$ & & $\begin{array}{l}\text { nento } \\
\text { lo }\end{array}$ & \multirow{3}{*}{$\begin{array}{c}\text { Dúvida } \\
\text { (argumento) }\end{array}$} & $\begin{array}{l}\text { Argumento } \\
\text { ausente }\end{array}$ \\
\hline & & \multirow{2}{*}{$\begin{array}{c}\text { Qts } \\
\text { verbos }\end{array}$} & \multicolumn{2}{|c|}{ VTD/VTDI } & \multicolumn{2}{|c|}{ VTD/VTDI } & & VTD/VTDI \\
\hline & & & Ext. & Int. & Ext. & Int. & & V \\
\hline 1 & $\operatorname{VC4}(10)$ & 8 & 6 & 4 & 2 & 4 & 1 & 1 \\
\hline 2 & JA5(11) & 6 & 1 & 2 & 5 & 2 & \# & 2 \\
\hline 3 & LF5(11) & 3 & 1 & 1 & 2 & 2 & \# & \# \\
\hline 4 & LH5(11) & 4 & 1 & 2 & 3 & 2 & \# & \# \\
\hline \multicolumn{2}{|c|}{ TOTAL } & 21 & 9 & 9 & 12 & 10 & 1 & 3 \\
\hline
\end{tabular}


Obs.: Símbolo \# (hashtag) marca que nenhum foi marcado na análise do quadro.

Em relação aos participantes de $4^{\circ}$ ao $5^{\circ}$ ano do ensino fundamental, encontramos o preenchimento da estrutura argumental com verbos VTD/ VTDI. A maioria dos participantes realizou a posição do sujeito com o argumento nulo (12), que pode ser ou não recuperado pela antecedente. Encontramos 10 (dez) casos de verbos (VTD/VTDI) com argumento interno nulo, isto é, não realizaram a posição de objeto direto ou indireto. $\mathrm{O}$ argumento externo está presente em 9 (nove) casos. Em um dado não sabemos definir a estrutura sintática e em 3 dados o verbo ocorre isolado, ou seja, estão ausentes o argumento externo e o(s) argumento(s) interno(s).

No quadro A2b, abaixo, apresentamos a quantificação do preenchimento da estrutura argumental de verbos intransitivos (VI) encontrados nas narrativas:

Quadro A2b - Preenchimento da estrutura argumental VI - Participantes de $4^{\circ}$ ao $5^{\circ}$

\begin{tabular}{|c|c|c|c|c|c|c|c|c|}
\hline & VI & $\begin{array}{r}\text { Argu } \\
\text { Pre } \\
\end{array}$ & $\begin{array}{l}\text { ento } \\
\text { nte }\end{array}$ & $\begin{array}{r}\text { Argu } \\
\mathrm{N} \\
\end{array}$ & $\begin{array}{l}\text { ento } \\
\text { o } \\
\end{array}$ & \multirow{3}{*}{$\begin{array}{c}\text { Dúvida } \\
\text { (argumento) }\end{array}$} & $\begin{array}{c}\text { Argumento } \\
\text { Ausente }\end{array}$ \\
\hline & & \multirow{2}{*}{$\begin{array}{c}\text { Qts } \\
\text { verbos }\end{array}$} & \multicolumn{2}{|c|}{ VI } & \multicolumn{2}{|c|}{ VI } & & VI \\
\hline & & & Ext. & Int. & Ext. & Int. & & $\mathrm{V}$ \\
\hline 1 & VC4(10) & 4 & 2 & 1 & 1 & \# & 1 & \# \\
\hline 2 & JA5(11) & 6 & 4 & \# & 2 & \# & \# & \# \\
\hline 3 & LF5(11) & 7 & 3 & \# & 4 & \# & \# & $\#$ \\
\hline 4 & LH5(11) & 4 & 3 & \# & 1 & \# & \# & $\#$ \\
\hline \multicolumn{2}{|c|}{ TOTAL } & 21 & 12 & 1 & 8 & \# & 1 & \# \\
\hline
\end{tabular}

Observamos os participantes de $4^{\circ}$ ao $5^{\circ}$ ano do ensino fundamental, em relação ao preenchimento da estrutura argumental VI. Passamos a explicar o resultado do quadro acima: notamos que, proporcionalmente, os participantes preencheram mais o argumento externo do que VTD/VTDI. Nossa hipótese é que o VI tem um argumento apenas, e o significado do verbo depende desse argumento. Podemos concluir que os alunos sabem preencher a posição do sujeito com o argumento presente (12) ou com o argumento nulo (8). Temos um dado com o verbo inacusativo 'sair', que seleciona um argumento interno. Um dado apresenta dúvida por falta de esclarecimento da estrutura sintática. 


\section{Grupo B: $8^{\circ}$ e $9^{\circ}$ ano}

Selecionamos o participante RA8(15), e verificamos os verbos que aparecem no texto, que podem ser classificados como verbo transitivo direto (VTD) e transitivo direto e indireto (VTDI) e verbo intransitivo (VI).

Vejamos o quadro B1 com frases retiradas da produção de texto do participante RA8(15) com verbos transitivos diretos (VTD) e transitivos diretos e indiretos (VTDI):

Quadro B1a: Verbo transitivo direto (VTD) e Verbo transitivo direto e indireto (VTDI)

\begin{tabular}{|c|c|c|c|c|}
\hline FRASES RETIRADAS DO TEXTO & $\begin{array}{c}\text { QTS } \\
\text { ARGUMENTOS }\end{array}$ & EXTERNO & INTERNO $_{1}$ & INTERNO $_{2}$ \\
\hline Cascão falar: & 3 & $\mathrm{x}$ & $\begin{array}{c}\mathrm{X} \\
\text { [oração } \\
\text { seguinte] }\end{array}$ & $\begin{array}{c}\varnothing \\
\text { [discurso } \\
\text { direto] }\end{array}$ \\
\hline $\begin{array}{l}\text { [Nós vamos] juntos prepara terra } \\
\text { plantar }\end{array}$ & 2 & $x$ & $x$ & \\
\hline Margarida [joga] semente & 2 & $x$ & $x$ & \\
\hline Cascão falar: Tchau Margarida & 3 & $x$ & $x$ & $\begin{array}{c}\varnothing \\
\text { [discurso } \\
\text { direto] }\end{array}$ \\
\hline Cebolinha pegar [mangueira] & 2 & $x$ & $\begin{array}{ll}--- \\
\end{array}$ & \\
\hline [para] aguar [plantas] & 2 & $\varnothing$ & $\begin{array}{ll}--- \\
\end{array}$ & \\
\hline $\begin{array}{l}\text { [ele] Prescia [Precisa] água [para] } \\
\text { plantar }\end{array}$ & 2 & $\mathrm{x}$ & $\mathrm{x}$ & \\
\hline Cebolinha pegar escada [e] cesta & 2 & $\mathrm{x}$ & $x$ & \\
\hline [Ele] pegar maçã & 2 & $\varnothing$ & $x$ & \\
\hline Cascão falar: & 3 & $\mathrm{x}$ & $\begin{array}{c}\mathrm{X} \\
\text { [oração } \\
\text { seguinte] }\end{array}$ & $\begin{array}{c}\varnothing \\
\text { [discurso } \\
\text { direto] }\end{array}$ \\
\hline [Eu] ajudar [vocês] & 2 & $\varnothing$ & $\varnothing$ & \\
\hline [Cebolinha] aceitou [ajuda] sim & 2 [?] & $\varnothing$ & ---- & \\
\hline Florzinha levar pessoas & 2 & $\mathrm{X}$ & $\mathrm{x}$ & \\
\hline $\begin{array}{l}\text { Cascão falar: [eu vou] sair / muito } \\
\text { obrigado, amiga (o) Florzinha }\end{array}$ & 3 & $\mathrm{x}$ & $\begin{array}{c}\mathrm{X} \\
\text { [oração } \\
\text { seguinte] }\end{array}$ & $\begin{array}{c}\varnothing \\
\text { [discurso } \\
\text { direto] }\end{array}$ \\
\hline
\end{tabular}

No Quadro B1, mostramos que o participante preenche a posição de sujeito com argumento externo para introduzir os personagens da narrativa. Quanto ao complemento (argumento interno) notamos que o participante preenche quase todos. Em 4 (quatro) dados, ocorre o sujeito nulo, que pode ser recuperado pelo antecedente e em um dado do complemento ocorre objeto nulo. No Quadro B1a, observamos ainda que o verbo transitivo direto e indireto 'falar', que apresenta 3 (três) argumentos, tem 4 (quatro) ocorrências. No entanto, em todas as ocorrências o verbo 'falar' introduz o discurso 
direto. $\mathrm{O}$ argumento interno interpretado como alvo é nulo, pois o falante se dirige diretamente ao seu interlocutor. O outro argumento interno é o conteúdo do que é falado, ou seja é o tema e ocorre no diálogo.

\section{Quadro B1b - Verbo intransitivo}

\begin{tabular}{|c|c|c|c|}
\hline FRASES RETIRADAS DO TEXTO & $\begin{array}{c}\text { QTS } \\
\text { ARGUMENTOS }\end{array}$ & EXTERNO & INTERNO \\
\hline $\begin{array}{c}\text { Acabou [de colher maçã] Magai } \\
\text { (Magali)/ acabou [maçã] }\end{array}$ & 1 [?] & & $X$ \\
\hline [Florzinha] aceitou [ajudar] sim & 1 & $\varnothing$ & \\
\hline [Eu vou] sair/ muito obrigado & 1 & & $\varnothing$ \\
\hline
\end{tabular}

No Quadro B1b, acima, em 2 (dois) dados ocorre o verbo intransitivo. O primeiro dado permite duas análises: em uma, o verbo 'acabar' forma uma locução com outro verbo, como acabou de colher, e o verbo seleciona um argumento interno, 'maçã'; em outra análise, o verbo 'acabar' é intransitivo, e temos de perguntar: o que acabou? Pode ser que o participante esteja pensando que seria 'maçã', e nesse caso, o argumento é nulo, recuperado pelo contexto. O segundo dado é o verbo 'sair', que é um verbo inacusativo de movimento, e possui um argumento interno que é o sujeito nulo, que pode ser recuperado pela antecedente.

No quadro B2a, abaixo, apresentamos a quantificação do preenchimento da estrutura argumental de verbos transitivos diretos (VTD) e transitivos diretos e indiretos (VTDI) encontrados nas narrativas:

Quadro B2a - Preenchimento da estrutura argumental VTD/ VTDI

- Participantes de $8^{\circ}$ ao $9^{\circ}$

\begin{tabular}{|c|c|c|c|c|c|c|c|c|}
\hline & $\begin{array}{l}\text { VTD/ } \\
\text { VTDI }\end{array}$ & $\begin{array}{r}\text { Argl } \\
\text { Pre }\end{array}$ & $\begin{array}{l}\text { ento } \\
\text { nte }\end{array}$ & & $\begin{array}{l}\text { iento } \\
\text { o }\end{array}$ & \multirow{3}{*}{$\begin{array}{c}\text { Dúvida } \\
\text { (argumento) }\end{array}$} & $\begin{array}{c}\text { Argumento } \\
\text { Ausente }\end{array}$ \\
\hline & & \multirow{2}{*}{$\begin{array}{l}\text { Qts } \\
\text { verbos }\end{array}$} & \multicolumn{2}{|c|}{ VTD/VTDI } & \multicolumn{2}{|c|}{ VTD/VTDI } & & VTD/VTDI \\
\hline & & & Ext. & Int. & Ext. & Int. & & $\mathrm{V}$ \\
\hline 1 & IS8(18) & 10 & 5 & 9 & 5 & 3 & \# & 1 \\
\hline 2 & MM8(16) & 13 & 6 & 6 & 7 & 3 & $\#$ & 4 \\
\hline 3 & RA8(15) & 14 & 10 & 10 & 4 & 1 & 1 & 3 \\
\hline 4 & RS8(20) & 8 & 3 & 7 & 5 & 1 & \# & 1 \\
\hline 5 & TR8(14) & 13 & 7 & 9 & 6 & 2 & $\#$ & 2 \\
\hline 6 & ВH9(19) & 9 & 5 & 6 & 4 & 2 & 1 & 1 \\
\hline 7 & EL9(19) & 7 & 4 & 6 & 3 & 1 & $\#$ & 1 \\
\hline \multicolumn{2}{|c|}{ TOTAL } & 74 & 40 & 53 & 34 & 13 & 2 & 13 \\
\hline
\end{tabular}


Obs.: Símbolo \# (hashtag) marca como nenhum foi marcado na análise da tabela.

Em relação aos participantes de $8^{\circ}$ ao $9^{\circ}$ ano, encontramos o seguinte resultado do preenchimento da estrutura argumental VTD/ VTDI. A posição do objeto com argumento presente em 53 dados, e a posição de sujeito com o argumento externo presente em 40 dados. $\mathrm{O}$ argumento nulo ocorre em 34 dados na posição de argumento externo e em 13 dados ocorre na posição do objeto nulo que pode ser recuperado pela antecedente. Os argumentos foram considerados ausentes em 13 dados. Em 2 (dois) dados temos dúvida em relação à estrutura da oração.

No quadro B2b, abaixo, apresentamos a quantificação do preenchimento da estrutura argumental de VI encontrado nas narrativas:

Quadro B2b - Preenchimento da estrutura argumental VI - Participantes de $8^{\circ}$ ao $9^{\circ}$

\begin{tabular}{|c|c|c|c|c|c|c|c|c|}
\hline & VI & \multirow{2}{*}{\multicolumn{2}{|c|}{$\begin{array}{c}\begin{array}{c}\text { Argumento } \\
\text { Presente }\end{array} \\
\text { VI }\end{array}$}} & \multirow{2}{*}{\multicolumn{2}{|c|}{$\begin{array}{c}\begin{array}{c}\text { Argumento } \\
\text { Nulo }\end{array} \\
\text { VI }\end{array}$}} & \multirow{3}{*}{$\begin{array}{c}\text { Dúvida } \\
\text { (argumento) }\end{array}$} & \multirow{2}{*}{$\begin{array}{c}\begin{array}{c}\text { Argumento } \\
\text { Ausente }\end{array} \\
\text { VI } \\
\end{array}$} \\
\hline & & \multirow{2}{*}{$\begin{array}{l}\text { Qts } \\
\text { verbos }\end{array}$} & & & & & & \\
\hline & & & Ext. & Int. & Ext. & Int. & & $\mathrm{V}$ \\
\hline 1 & IS8(18) & 3 & 1 & $\#$ & 2 & \# & \# & \# \\
\hline 2 & MM8(16) & 4 & 2 & $\#$ & 2 & $\#$ & $\#$ & $\#$ \\
\hline 3 & RA8(15) & 3 & 1 & \# & 2 & \# & 1 & $\#$ \\
\hline 4 & RS8(20) & 2 & 1 & $\#$ & 1 & \# & \# & \# \\
\hline 5 & TR8(14) & 2 & 2 & $\#$ & \# & $\#$ & $\#$ & $\#$ \\
\hline 6 & BH9(19) & 3 & \# & 2 & 1 & \# & $\#$ & $\#$ \\
\hline 7 & EL9(19) & 4 & 3 & $\#$ & 1 & $\#$ & $\#$ & $\#$ \\
\hline & TOTAL & 21 & 10 & 2 & 9 & \# & 1 & \# \\
\hline
\end{tabular}

Em relação aos participantes de $8^{\circ}$ ao $9^{\circ}$ ano, encontramos o seguinte preenchimento da estrutura argumental de verbos intransitivos (VI). Mostramos no resultado que 10 dados com argumento presente ocorrem na posição do sujeito e 9 (nove) dados com argumento nulo na posição de sujeito. Em 2 (dois) dados ocorre o argumento interno presente na posição de sujeito com o verbo 'sair' e 'nascer', são verbos inacusativos, portanto os verbos selecionam apenas um argumento interno. Em um dado, temos dúvida no sentido e, portanto, demos dúvida em relação à estrutura sintática. 
O quadro A+B apresenta o preenchimento da estrutura argumental de todos os dados coletados nesta pesquisa.

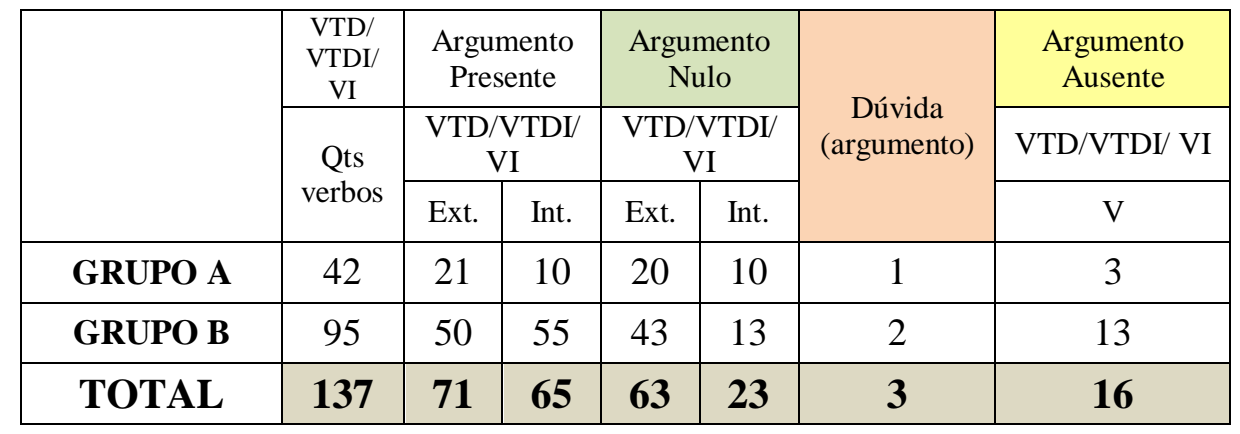

Verificamos o resultado geral da quantificação em relação à realização sintática da estrutura argumental: o grupo de $4^{\circ}$ e $5^{\circ}$ ano com 42 verbos produzidos de textos e o grupo de $8^{\circ}$ e $9^{\circ}$ ano com 95 verbos. Comparamos esses dados do desenvolvimento linguístico nos níveis de escolaridade e verificamos que os participantes adquiriram novos itens lexicais. A aprendizagem indica que o input oferecido aos aprendizes foi significativo e por isso os participantes são capazes de descrever suas ideias para produzir o texto em português.

Verificamos que os participantes dos grupos A e B conseguiram preencher a posição do sujeito e do objeto das sentenças. No entanto, o grupo A apresentou 21 dados com argumento (externo) e 1 (um) dado com argumento interno do verbo inacusativo e 10 dados com argumento interno na posição de objeto. No grupo B, os participantes conseguiram a mesma quantidade de argumentos externo e interno: 50 dados com argumento externo e 2 (dois) dados com argumento interno de verbo inacusativo e 55 dados com argumento interno, respectivamente. Portanto, considerando que o nível escolar do Grupo B é mais adiantado, esse resultado mostra que os participantes já sabem construir melhor a estrutura sintática para ter bom resultado da produção de texto.

Além disso, os resultados mostram que existem muitos casos de argumento nulo. Assim, a posição do sujeito nulo e do objeto nulo é muito usada. Considerando sentenças com VTD e VTDI, o resultado mostra que o grupo A usa mais argumentos nulos do que argumentos presentes. Nas sentenças transitivas, foram encontradas 12 ocorrências sujeito nulo e 10 de objeto nulo $(12+10=22)$, e 9 (nove) ocorrências de sujeitos presente e 9 (nove) de objeto (direto/indireto) presente. No grupo B, 
verificamos que os participantes construíram mais sentenças com o sujeito e o objeto presente do que com o sujeito nulo e o objeto nulo. Nas sentenças transitivas, foram encontradas 34 ocorrências de sujeito nulo e 13 sentenças com objeto nulo, e 40 ocorrências de sujeito presente e 53 ocorrências de objeto presente.

A presença de argumentos nulos pode ser explicada pela possibilidade de recuperar a referência por um antecedente na narrativa nos grupos A e B. O argumento realizado na função de sujeito e de objeto em maior número no grupo B indica que os participantes preenchem as funções sintáticas da oração. Esse resultado confirma a hipótese, pois o grupo B, que recebeu mais input linguístico, apresenta desenvolvimento linguístico em relação ao grupo A, que recebeu menos input linguístico, pois é menos adiantado academicamente. 


\section{CAPITIOLO V}

\section{CONSIDERAÇÕES FINAIS}

Neste estudo, abordamos nos capítulos anteriores, a realização da posição de sujeito e de objeto, tendo como foco a estrutura argumental do predicado, na interlíngua de surdos aprendizes de português (L2). Para examinar a interlíngua de surdos, observamos a expressão morfossintática dos argumentos internos e externos dos verbos nas frases, considerando a interferência da L1 na interlíngua.

Sabemos que a primeira língua do surdo é a língua de sinais. Quando qualquer aluno surdo é matriculado na escola, na faixa etária acima de 10 a 20 anos, a pergunta é: onde ele pode aprender sua língua? Qual é a língua que ele deve aprender: LIBRAS ou língua portuguesa? No passado, os surdos tinham de aprender o português e muitas vezes não aprendiam a língua de sinais (pois os pais, na maioria ouvintes, e não conheciam essa língua e a escola também não conhecia a língua de sinais). Essa situação mudou, e hoje a língua de sinais ganhou espaço nas famílias, na escola e na sociedade. Nosso trabalho mostra esse avanço, na situação linguística e cultural dos surdos, pois desenvolvemos a pesquisa de campo em uma escola bilíngue, onde os estudantes surdos recebem instrução em LIBRAS e aprendem o português L2 escrito.

Fizemos um estudo da situação socioeducacional dos surdos que participaram de nossa pesquisa. Identificamos, na pesquisa realizada, que a maioria dos surdos são filhos de pais ouvintes e essa situação pode dificultar sua aquisição da L1 e também da L2. Em nossa pesquisa, partimos da hipótese de que o início do processo da aquisição da primeira língua (L1) tem a Gramática Universal (GU) representada na mente do indivíduo, que é uma capacidade inata. Uma segunda hipótese de nosso trabalho considera que a L1 é o estado mental inicial para a aquisição de segunda língua (L2).

Em relação à segunda língua, como uma necessidade social, as comunidades surdas precisam assumir, adquirir, compreender, saber ler e escrever a língua oficial do Brasil, que é a Língua Portuguesa. Com a Lei 10.436/2002 que reconhece a Língua Brasileira de Sinais como língua oficial da comunidade surda, a comunidade se torna bilíngue, pois a LIBRAS passa a ser obrigatória na formação acadêmica dos estudantes surdos. Além disso, fomos à escola onde os alunos estudam com acesso à educação bilíngue (Língua de Sinais Brasileira (LIBRAS) e português na modalidade escrita), e 
observamos em nosso trabalho de campo as atividades na escola, assistimos as aulas e pegamos as informações das aulas de português e LIBRAS. Anotamos também que a escola tem suas disciplinas como matemática, geografia, ciências, história, arte com as aulas ministradas por professores usuários de Libras.

Antes de fazer esta pesquisa, tivemos contato com aprendizes de português como segunda língua de outra instituição, que tinham dificuldade de argumentar, de entender os textos, porém, percebemos que a escrita do português não era de sua primeira língua e sim uma interlíngua, pois era uma situação de aquisição de português como L2. No entanto, o input linguístico será muito importante para o estudante surdo adquirir o conhecimento da regra gramatical do português.

Este trabalho foi realizado em uma instituição educacional bilíngue (LIBRAS e português (escrito)) em Uberaba-MG. Essa instituição, em suas atividades pedagógicas, exercita os alunos surdos no uso de duas línguas, como estudantes bilíngues. Ou seja, as atividades pedagógicas consideram que as línguas de sinais são distintas das línguas orais (em modalidade escrita), e podem transmitir suas informações, expressar os pensamentos mais complexos, as ideias mais abstratas e objetivas.

Exatamente por essa razão o surdo pode adquirir a língua oral na modalidade escrita como segunda língua. Mas para isso acontecer, é preciso que o estudante surdo tenha acesso aos dados da língua, para que possa adquirir a regra gramatical que determina o uso das categorias lexicais e gramaticais. Em nosso trabalho discutimos a aquisição da gramática, pois trabalhamos para analisar a realização sintática da estrutura argumental, buscando identificar como os argumentos são colocados na posição do sujeito e objeto do predicado. Este estudo adotou uma metodologia de pesquisa exploratória, qualitativa e quantitativa.

Para analisar os dados, fizemos um estudo teórico sobre a ordem dos constituintes em LIBRAS, a classificação dos verbos em relação à estrutura argumental e o sistema pronominal no português e em LIBRAS. Para a análise dos dados da produção escrita desses participantes surdos, partimos da hipótese de que a L1 intervém na estrutura da interlíngua dos aprendizes de português como segunda língua.

De acordo com Quadros (2006), a interferência da L1 sobre a L2, os 'erros' cometidos por aprendizes de L2 podem ocorrer por falta ou inadequação de elementos funcionais (artigos, preposições, conjunções, verbos de ligação), pode ser a existência de irregularidades nas flexões nominais e verbais, falta de argumentos dos predicados, de pronomes de pessoas e ainda a ausência de pontuação nos textos elaborados pelos 
surdos. Neste trabalho, fizemos a investigação dessas questões, considerando em particular a falta de argumentos dos predicados e a falta de pronomes, pela análise controlada do processo de aquisição dessas estruturas, por meio de uma metodologia transversal, que considere o acesso ao input do português L2 no processo educacional.

Neste estudo, mostramos a realização sintática dos argumentos na aquisição de português pelos aprendizes de português L2. Ficou demonstrado que existe dificuldade na realização sintática dos argumentos do predicado na estrutura oracional, por meio do preenchimento da posição sintática de sujeito e de complemento e do uso da flexão verbal.

Os alunos foram divididos em dois grupos, do $4^{\circ}$ e do $5^{\circ}$ ano, e do $8^{\circ}$ e do $9^{\circ}$ ano. A hipótese é que nas séries iniciais, os estudantes receberam menos input e vão ter mais dificuldade no preenchimento dos argumentos na posição de sujeito e de objeto do que os estudantes do grupo mais adiantados. Apresentamos várias atividades e escolhemos duas. Na atividade 1 , os estudantes deveriam escrever sentenças a partir de verbos da língua de LIBRAS apresentados em imagens. Na atividade 2, os estudantes deveriam escrever uma narrativa a partir de imagens em sequência, que contavam um pequeno episódio.

Sabemos que, no contexto escolar, os alunos têm diferentes níveis de proficiência na Língua Portuguesa (na modalidade escrita). Analisamos a realização dos argumentos interno e externo na estrutura sintática e os resultados foram os seguintes:

1. $\mathrm{Na}$ atividade 1 , observamos que o argumento externo está mais ausente do que o interno. Nossa hipótese é que o argumento interno forma com o verbo uma unidade de significado, por isso ocorre o preenchimento. Na posição de sujeito, o argumento é nulo. Acreditamos que, nesse caso, ocorre interferência da L1, pois na $1^{\text {a }}$ pessoa, o sujeito é nulo, pois sinal o ponto de articulação do sinal é realizado no próprio corpo.

2. Comparando os resultados do grupo A e do grupo B, verificamos que existe mais preenchimento das posições de sujeito e de objeto no grupo B. Isso confirma a hipótese do desenvolvimento linguístico.

3. Na atividade 2, como na atividade 1, encontramos argumentos nulos na posição de sujeito e de objeto. No entanto, observamos que, no Grupo B, existe mais preenchimento do argumento externo e do argumento interno do que no Grupo A. 
4. Verificamos também que os participantes do Grupo B produziram um número maior de verbos do que os participantes do Grupo A. Esse resultado confirma a hipótese do desenvolvimento linguístico, pois os participantes do Grupo B estão mais adiantados e receberam mais input linguístico.

5. Um resultado que chamou a atenção nos Grupos A e B é que a maioria dos dados estão na ordem básica SVO, SV ou VO. Assim, nos dois grupos, existem poucos dados na ordem VSO e (S)OV. Esse resultado é esperado, pois a ordem básica em LIBRAS e em português é SVO.

6. Outro resultado que chamou a atenção é que os participantes dos Grupo A e B não utilizaram pronomes pessoais, nem na atividade 1 , nem na atividade 2 . Esse resultado mostra que existe uma dificuldade muito grande em relação ao uso dessa categoria funcional.

A fim de chegar em outro aspecto da motivação deste estudo, gostaríamos de observar que é necessário aprofundar as estratégias de ensino, para oferecer o input adequado, estudar mais novas teorias, analisar as estruturas das sentenças produzidas pelos alunos para buscar o conhecimento dos dados de sua interlíngua. Entendemos que a aquisição de L2 carece de inúmeras pesquisadores que continuem investigando a interlíngua dos surdos em contexto educacional para buscar informações para desenvolver metodologias de ensino-aprendizagem. Podemos contribuir nos estudos e pesquisas linguísticas da LIBRAS e da interlíngua do surdo aprendiz de português L2. 


\section{REFERÊNCIAS BIBLIOGRÁFICAS}

ADJENIAN, D. La especificidad de la interlengua y la idealización en el análisis de lenguas segundas em Liceras (ver nessas referências) (1992, p 158).

BRASIL. Decreto $n^{o}$ 5626, de 22 de dezembro de 2005. Brasília: Presidência da República, Casa Civil, Subchefia para assuntos jurídicos. Disponível em http:// http://www.presidencia.gov.br/ccivil/__Ato2004-2006/2005/Decreto/D5626.htm. Acesso em 18 de abr 2008.

. Lei 10.436, de 24 de abril de 2002, que dispõe sobre a Língua Brasileira de Sinais - Libras. Disponível em: http://www.planalto.gov.br/ccivil_03/leis/2002/ 110436.htm Acesso em: 15 ago. 2013.

CAPOVILlA, F. C; RAPHAEL, W. D. Dicionário Enciclopédico Ilustrado Trilíngue da Lingua de Sinais Brasileira. $2^{\text {a }}$ edição - São Paulo: Editora da Universidade de São Paulo: Imprensa Oficial do Estado, 2001.

CHOMSKY, N. Aspects of the Theory of Syntax. Cambridge, MA: MIT Press, 1965.

O Conhecimento da Língua - sua natureza, origem e uso. Trad. Anabela Gonçalves e Ana Teresa Alves (1994). Lisboa: Caminho,1986.

The minimalism program. Cambridge, Massachusetts: The MIT Press, 1995.

CUNHA, C. \& CINTRA, L. Nova gramática do Português Contemporâneo. Lexikon, São Paulo, $5^{\text {a }}$ ed., 1985/2010.

CYRINO, S. Objeto Nulo no Português do Brasil- um estudo sintático diacrônico. Londrina, Ed. da Universidade de Londrina, 1997.

ELLIS, R. The Study of Second Language Acquisition. Oxford: Oxford University Press, 1994.

FELIPE, T. A. A Relação Sintático-Semântica dos Verbos e seus Argumentos na Língua de Sinais Brasileira - LIBRAS - Tese de doutorado. Volume II. Rio de Janeiro: Universidade Federal do Rio de Janeiro. 1998.

FELIPE, T. A. \& MONTEIRO M. S. Libras em Contexto : Curso Básico : Livro do Professor/instrutor. Brasília: Programa Nacional de Apoio à Educação dos Surdos, MEC: SEESP, 2007.

FERREIRA, G. A. Um estudo sobre os verbos manuais da Lingua de Sinais Brasileira (LSB). Dissertação (Mestrado em Linguística) - Universidade de Brasília, 2013.

FERREIRA-BRITO, L. Por uma gramática de línguas de sinais. Rio de Janeiro: Tempo Brasileiro, 1995. 
A aquisição do português por surdos sob uma perspectiva semânticopragmática. In: Anais do III Congresso da SIPLE - Desafios e respostas para o ensino de português como segunda língua. Universidade de Brasília, Brasília, 2001.

GRANNIER, Daniele Marcelle. Português por escrito para usuários de Libras. Revista integração. Ministério da Educação. Secretaria de Educação Especial. Brasília. Ano14 $\mathrm{n}^{\mathrm{o}} 24, \mathrm{p} .49-51,2002$.

GREENBERG, J. H. Universals of language. Cambridge: MIT Press, 1966.

KENEDY, E. Curso básico de linguística gerativa. São Paulo: Contexto, 2013.

KLIMA, E. \& BELLUGI, U. The signs of language. 1.ed. Cambridge, Mass.:Harvard University Press, 1979.

LEHMANN, W. P. (Ed.) Sintactic typology. Sussex: The Harvester Press, 1978.

LILLO-MARTIM, D. \& KLIMA, E. Pointing out diferences: ASL pronouns in syntactic theory. In: Theorical issues in sign language research. v.1: Linguistics. Chicago, IL: University of chicago Press, 1990, p. 191-210.

LIMA, M. D. Um estudo sobre aquisição de ordem e concordância no português escrito por surdos. Dissertação de Mestrado em Linguística. Universidade de Brasília DF, 2011.

LIMA-SALLES, H. M. M. e NAVES, R. R. (org) Estudos gerativos de língua de sinais brasileira e de aquisição do português (L2) por surdos. Goiânia: Cânone Editorial, 2010.

LYONS, J. Lingua(gem) e Lingüística: uma introdução. Rio de Janeiro: LTC, 1987.

MEIR, I., PADDEN, C., ARONOFF, M. e SANDLER, W. Repensando classes verbais em linguas de sinais: $O$ corpo como sujeito. In: QUADROS, R. M.; VASCONCELLOS, M. L. B. (Org.). Questões teóricas das pesquisas em línguas de sinais. Petrópolis, RJ: ED. Arara Azul, 2008, p. 87-106.

MIOTO, Carlos; FIGUEIREDO-SILVA, Maria C.; LOPES, Ruth E. V. Novo Manual de Sintaxe. $3^{\mathrm{a}}$ ed. Florianópolis: Insular, 2007. $3^{\mathrm{a}}$ ed., 2007. 280p.: il. ISBN 85-7474199-x

NEMSER, W. "Approximative system of foreign language learners" em IRAL IX, 1994.

PETITTO, L.A. \& MARENTETTE, P. Babbling in the manual mode: Evidence for the ontogeny of language. Reprinted from: Science, vol. 251,(pages 1483-1496), 1991.

PEZATTI, E. G. A ordem de palavras e o caráter nominativo/ergativo do português falado. Alfa, São Paulo, p. 159-178, 1993. 
QUADROS, R. M \& KARNOPP, L. B. Língua de Sinais Brasileira: Estudos lingüísticos. Porto Alegre: Artmed, 2004.

2006.

“Idéias para ensinar português para alunos surdos”. Brasília: MEC, SEESP,

QUADROS, R. M. "Aquisição de L1 e L2: o contexto da pessoa surda”. Paper apresentado no Seminário Desafios e possibilidades na Educação bilíngüe para Surdos, Santa Catarina: UFSC. Anais. Santa Catarina, 1997b p.70-87. Disponível em: <http://www.ronice.ced.ufsc.br/publicacoes/contexto.pdf> Acesso em: 07 nov. 2010.

1997.

Educação de surdos: a aquisição da linguagem. Porto Alegre: Artes Médicas,

Phrase structure of Brazilian sign language. Teste de Doutorado. Porto Alegre: PUC/RS, 1999.

RABELO, P. C. Argumentos (EPP) nulos no português do Brasil em contextos oracionais finitos e infinitivos. Tese de Doutorado em Linguística. Universidade de Brasília - DF, 2010.

RAPOSO, E. P. Teoria da gramática: a faculdade da linguagem. Lisboa: Editorial Caminho, 1992.

ROBERTS, I. Diachronic Syntax. Oxford: Oxford University Press, 2007.

SALLES, H. M. M. L. et al. Ensino de Língua Portuguesa para Surdos: caminhos para a prática pedagógica. Brasília: MEC/SEESP, 2004.

SELINKER, L. Interlanguage. In: IRAL vol. 10, no. 3, 1972, p. 209-231.

SILVA, M. da P. M. A construção de sentidos na escrita do aluno surdo. São Paulo: Plexus, 2001.

SVARTHOLM, K. Second language learning in the deaf. In: Bilinguism in deaf education. Ahlgren; Hyltenstam (eds) Hamburg: Signum-Verl, p. 61-70, 1994.

WHITE, L. Second Language Acquisition and Universal Grammar. Cambridge University Press, 2003. 
VII. ANEXOS

Anexo 1 


\section{FORMULÁRIO DE IDENTIFICAÇÃO DO ALUNO}

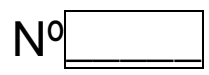

1. Nome completo:

Série/ano:

2. Sexo: ( ) masculino ( ) feminino

IDADE:

3. Local e data de nascimento:

4. Você nasceu surdo? （） Sim （） Não

5. Você ficou surdo com que idade? anos.

6. Sua surdez é... ( ) unilateral $\quad(\quad)$ bilateral

7. O seu grau de surdez é... ( ) leve ( ) moderada ( ) severa ( ) profunda

8. Você foi oralizado? ( ) Sim Não

9. Você se comunica oralmente... ( ) bem $\quad(\quad)$ mal $\quad(\quad)$ razoável

10. Você usa prótese auditiva? （ ) Sim （） Não

11. Seus pais são... ( ) surdos $(\quad)$ ouvintes

12. Você tem algum familiar surdo? ( ) Sim Não

13. Sua família fala a LIBRAS? ( ) sim ( ) não ( ) ás vezes

14. Você adquiriu/aprendeu LIBRAS com que idade? anos.

15. Onde e com quem você aprendeu LIBRAS?

16. Você começou a frequentar a escola com que idade? anos.

17. Você foi alfabetizado (começou a ler e a escrever) com que idade? anos.

18. O aluno escreve ( )muito bem( )bem ( ) pouco ( ) quase nada

19. Na sua casa você vê televisão com closed caption?

( ) sempre ( ) nunca ( ) ás vezes

20. O que você costuma ler? ( ) livros de história ( ) jornal ( ) site da internet ( ) e-mail ( ) revista ( ) história em quadrinhos 
Anexo 2 
Nome:

Série/ano:

Data:

Turno:

$\underline{\text { Atividade } 1}$

1 Crie frase de cada verbo:
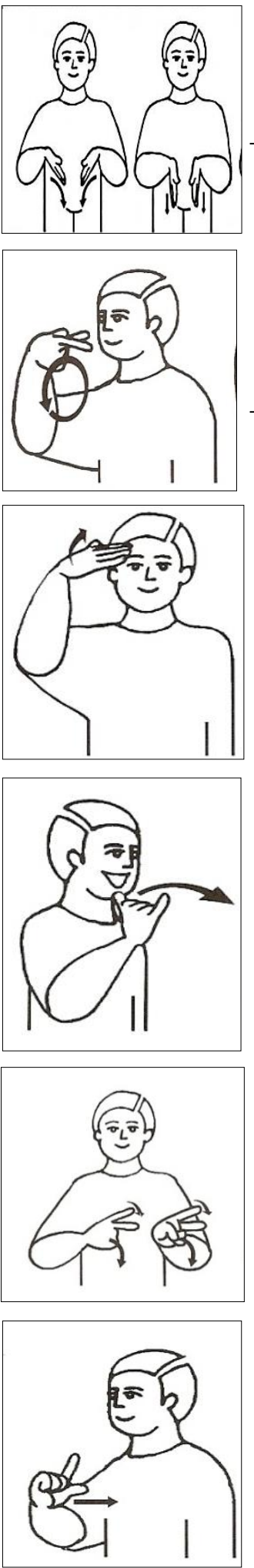

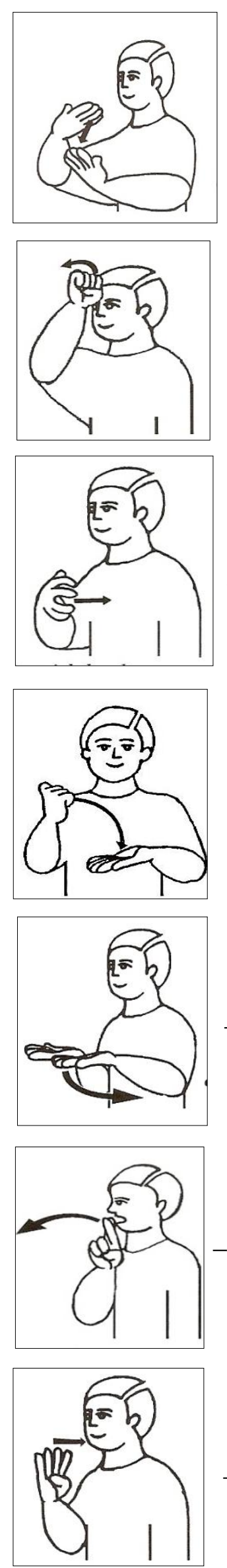
Nome:

Série/ano:

Data:

Turno:

\section{Atividade 2}

\section{HISTÓRIA EM SEQUÊNCIA}

Observe as cenas da história e explore em Língua Brasileira de Sinais (LIBRAS) os elementos apresentados na gravura, concretos e abstratos (objetos, ações, sentimentos, fenômenos da natureza, etc).

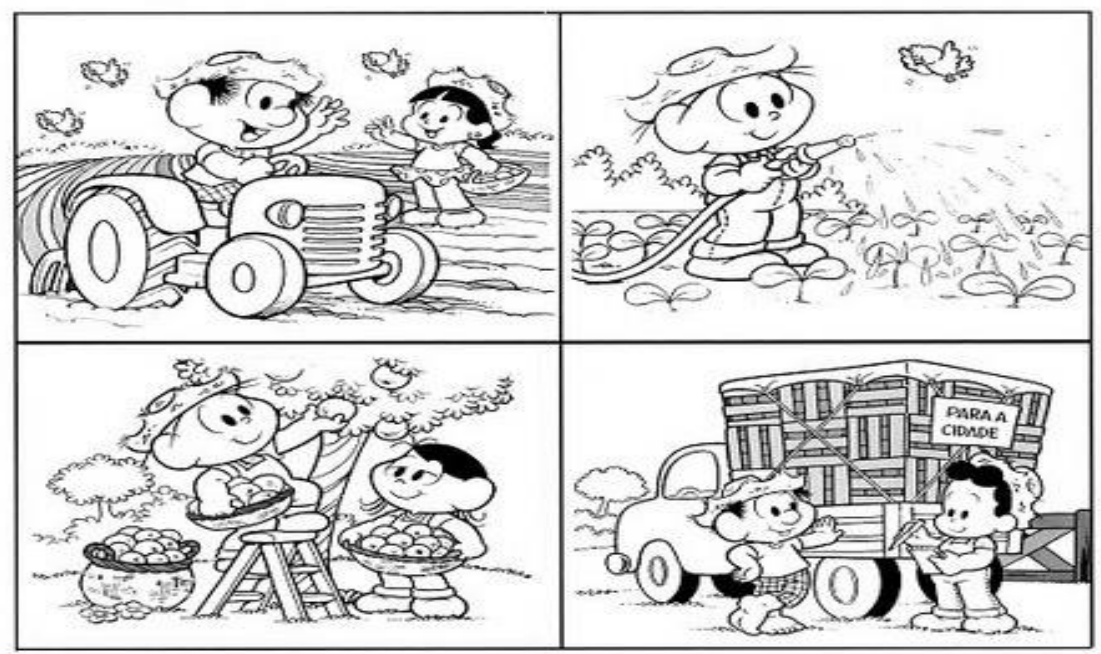

Fonte: http://picasaweb.google.com/Janny153/HistoriasEmSequencia\#5328395022096021202

Agora, crie um texto de acordo com as cenas e dê-lhe um título bem legal.

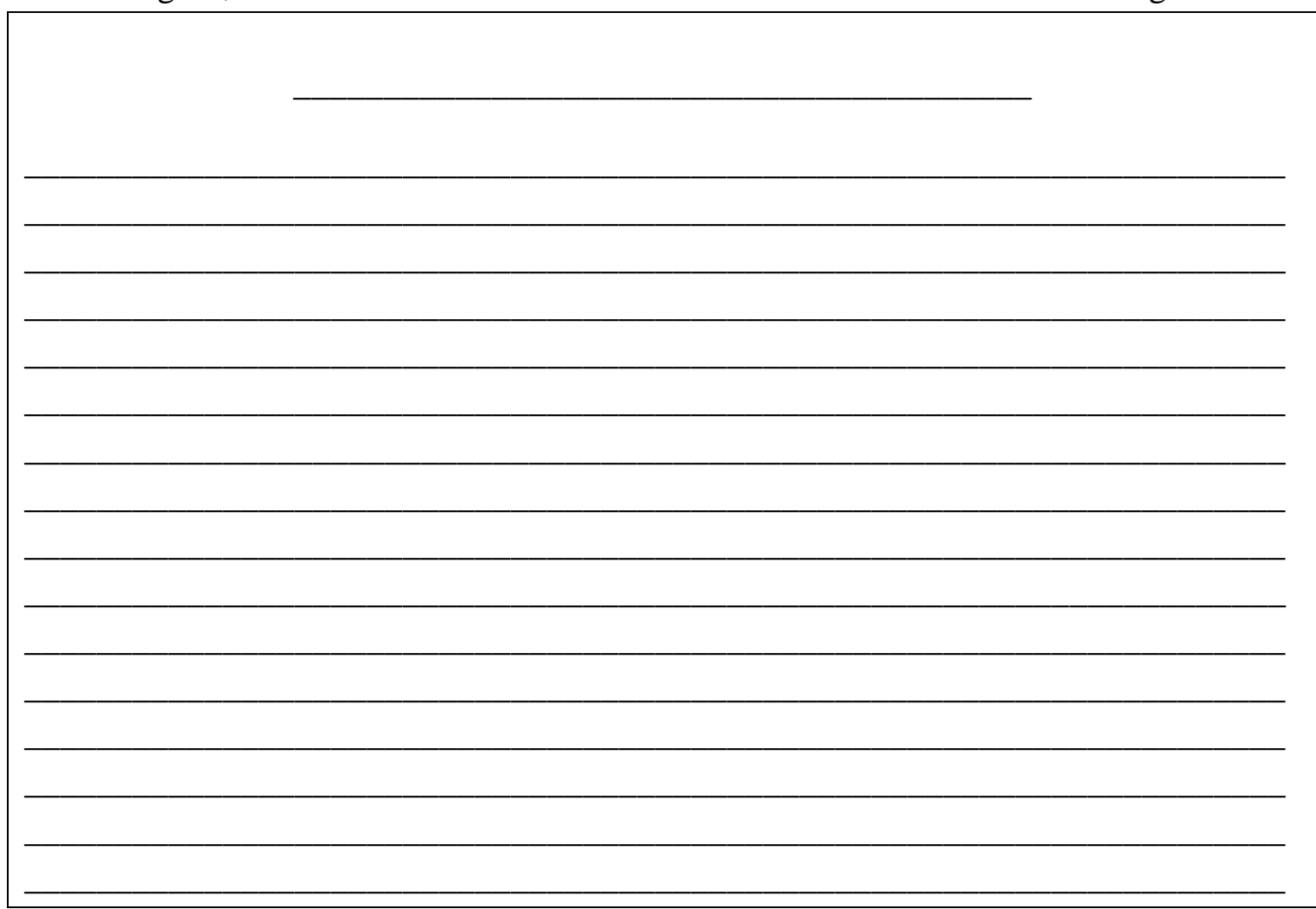


Anexo 3 


\section{INSTITUTO DE CIÊNCIAS \\ HUMANAS / UNIVERSIDADE \\ DE BRASÍLIA / CAMPUS}

\section{PARECER CONSUBSTANCIADO DO CEP}

\section{DADOS DO PROJETO DE PESQUISA}

Título da Pesquisa: A interlíngua de surdos aprendizes de português como segunda língua (L2): Uma análise da expressão sintática da estrutura argumental

Pesquisador: Hely César Ferreira

Área Temática:

Versão: 2

CAAE: 48483615.1 .0000 .5540

Instituição Proponente:

Patrocinador Principal: Financiamento Próprio

\section{DADOS DO PARECER}

Número do Parecer: 1.372.410

\section{Apresentação do Projeto:}

O projeto busca analisar as atividades de produções escritas pelos alunos surdos matriculados em contexto educacional, em uma escola para Surdos de Uberaba-MG. Parte da hipótese de que a aquisição da segunda língua (L2) é mediada pela primeira língua (L1 - no caso LIBRAS), com acesso parcial à Gramática Universal (GU), tem-se a observação de que, apesar da interferência de Libras, a interlíngua não viola os princípios da GU. Tem como hipótese que ocorre interferência da primeira língua (L1 - LIBRAS) no processo de aquisição da L2. Portanto, a interlíngua na modalidade escrita será diferente de produção escrita de um falante da LP que tem essa língua como L1. Metodologicamente, propõe um teste experimental, que consiste em atividades escritas em português a partir de um tema proposto livre e comum pela pesquisadora. Propõe também aplicar questionários de pesquisa de campo para a identificação dos sujeitos.

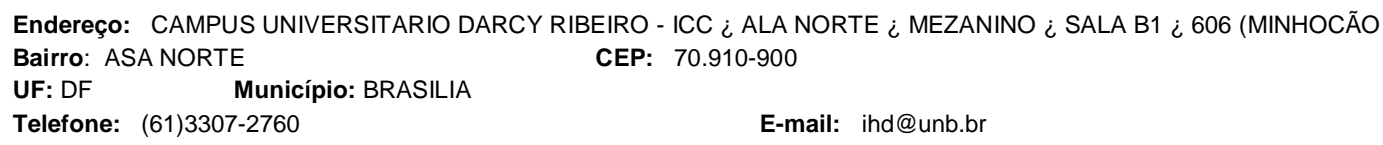




\section{INSTITUTO DE CIÊNCIAS HUMANAS / UNIVERSIDADE DE BRASÍLIA / CAMPUS}

Continuação do Parecer: 1.372 .410

A pesquisa pretende selecionar 19 indivíduos, sem, no entanto, justificar o número.

\section{Objetivo da Pesquisa:}

Analisar a produção escrita em língua portuguesa (LP) como segunda língua (L2) por surdos, investigando as características da interlíngua em relação à expressão morfossintática da estrutura argumental.

\section{Avaliação dos Riscos e Benefícios:}

A pesquisadora afirma que não há riscos aos participantes e não apresenta benefícios diretamente, embora afirme que a pesquisa servirá de fundamento teórico para a metodologia de ensino de português como segunda língua (L2).

\section{Comentários e Considerações sobre a Pesquisa:}

O projeto de pesquisa está adequado às exigências da Resolução CNS 466/2012 e complementares.

\section{Considerações sobre os Termos de apresentação obrigatória:}

Sem observações

Recomendações:

Conclusões ou Pendências e Lista de Inadequações:

Aprovado

Considerações Finais a critério do CEP:

Este parecer foi elaborado baseado nos documentos abaixo relacionados:

\begin{tabular}{|c|c|c|c|c|}
\hline Tipo Documento & Arquivo & Postagem & Autor & Situação \\
\hline $\begin{array}{l}\text { Informações } \\
\text { Básicas do Projeto }\end{array}$ & $\begin{array}{l}\text { PB_INFORMAÇŌES_BÁSICAS_DO_ } \\
\text { PROJETO_552488.pdf }\end{array}$ & $\begin{array}{c}22 / 09 / 2015 \\
14: 26: 58\end{array}$ & & Aceito \\
\hline Outros & Termo_de_responsabilidade_Hely.pdf & $\begin{array}{c}22 / 09 / 2015 \\
14: 17: 07\end{array}$ & Hely César Ferreira & Aceito \\
\hline Outros & Carta_de_encaminhamento_Hely.pdf & $\begin{array}{l}22 / 09 / 2015 \\
14: 16: 35\end{array}$ & Hely César Ferreira & Aceito \\
\hline Folha de Rosto & Folha_de_Rosto_Hely.pdf & $\begin{array}{c}22 / 09 / 2015 \\
14: 15: 47\end{array}$ & Hely César Ferreira & Aceito \\
\hline Outros & Questionario_Hely.pdf & $22 / 09 / 2015$ & Hely César Ferreira & Aceito \\
\hline
\end{tabular}

Endereço: CAMPUS UNIVERSITARIO DARCY RIBEIRO - ICC ¿ ALA NORTE ¿ MEZANINO ¿ SALA B1 ¿ 606 (MINHOCÃO Bairro: ASA NORTE

UF: DF Município: BRASILIA CEP: $70.910-900$

Telefone: (61)3307-2760

E-mail: ind@unb.br 


\section{INSTITUTO DE CIÊNCIAS HUMANAS / UNIVERSIDADE DE BRASÍLIA / CAMPUS}

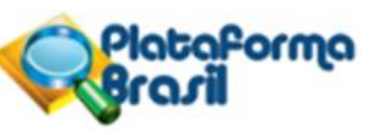

Continuação do Parecer: 1.372.410

\begin{tabular}{|c|c|c|c|c|}
\hline Outros & Questionario_Hely.pdf & $13: 56: 48$ & Hely César Ferreira & Aceito \\
\hline Outros & Carta_revisao_etica_Hely.pdf & $\begin{array}{c}22 / 09 / 2015 \\
13: 55: 41\end{array}$ & Hely César Ferreira & Aceito \\
\hline Cronograma & Cronograma_Projeto_Pesquisa_Hely.pdf & $\begin{array}{c}22 / 09 / 2015 \\
13: 51: 58\end{array}$ & Hely César Ferreira & Aceito \\
\hline $\begin{array}{l}\text { Projeto Detalhado } \\
\text { / Brochura } \\
\text { Investigador }\end{array}$ & $\begin{array}{l}\text { SUBMETER_PROJETO_PESQUISA_ } \\
\text { Hely.pdf }\end{array}$ & $\begin{array}{c}22 / 09 / 2015 \\
13: 49: 10\end{array}$ & Hely César Ferreira & Aceito \\
\hline Outros & Lattes_Hely.pdf & $\begin{array}{c}22 / 09 / 2015 \\
13: 44: 50\end{array}$ & Hely César Ferreira & Aceito \\
\hline Outros & Atividades_propostas_2_Hely.pdf & $\begin{array}{c}22 / 09 / 2015 \\
13: 39: 43\end{array}$ & Hely César Ferreira & Aceito \\
\hline Outros & Atividade_proposta_1_Hely.pdf & $\begin{array}{c}22 / 09 / 2015 \\
13: 39: 20\end{array}$ & Hely César Ferreira & Aceito \\
\hline Outros & Termo_de_autorizacao_Hely.pdf & $\begin{array}{c}\text { 22/09/2015 } \\
13: 35: 09\end{array}$ & Hely César Ferreira & Aceito \\
\hline Outros & Aceite_institucional_Hely.pdf & $\begin{array}{c}22 / 09 / 2015 \\
13: 31: 31\end{array}$ & Hely César Ferreira & Aceito \\
\hline $\begin{array}{l}\text { TCLE / Termos de } \\
\text { Assentimento / } \\
\text { Justificativa de } \\
\text { Ausência }\end{array}$ & Termo_de_assentimento_Hely.pdf & $\begin{array}{c}22 / 09 / 2015 \\
13: 28: 11\end{array}$ & Hely César Ferreira & Aceito \\
\hline $\begin{array}{l}\text { TCLE / Termos de } \\
\text { Assentimento / } \\
\text { Justificativa de } \\
\text { Ausência }\end{array}$ & TCLE_Hely.pdf & $\begin{array}{c}22 / 09 / 2015 \\
11: 15: 49\end{array}$ & Hely César Ferreira & Aceito \\
\hline
\end{tabular}

\section{Situação do Parecer:}

Aprovado

\section{Necessita Apreciação da CONEP:}

Não

BRASILIA, 16 de Dezembro de 2015

\section{Assinado por: \\ Lívia Barbosa \\ (Coordenador)}

Endereço: CAMPUS UNIVERSITARIO DARCY RIBEIRO - ICC ¿ ALA NORTE ¿ MEZANINO ¿ SALA B1 ¿ 606 (MINHOCÃO Bairro: ASA NORTE CEP: $70.910-900$

UF: DF Município: BRASILIA

E-mail: ind@unb.br 
Anexo 4 


\section{Termo de Assentimento}

$\mathrm{Eu}$ menor, estou sendo convidado

a participar da pesquisa "A INTERLÍNGUA DE SURDOS APRENDIZES DE PORTUGUÊS COMO SEGUNDA LÍNGUA (L2): UMA ANÁLISE DA EXPRESSÃO SINTÁTICA DA ESTRUTURA ARGUMENTAL. Este estudo tem como objetivo analisar a produção escrita em língua portuguesa (LP) como segunda língua (L2) por surdos, investigando as características da interlíngua em relação à expressão morfossintática da estrutura argumental. Fui informado pelo pesquisador HELY CÉSAR FERREIRA, RUA CORONEL MANOEL BORGES, 511 APTO 204, telefone (34) 9207-3248 de maneira clara e detalhada de todas as etapas da pesquisa. Sei que a qualquer momento poderei solicitar novos esclarecimentos e o meu responsável poderá modificar a decisão de participar se assim o desejar. Tendo o consentimento do meu responsável já assinado, declaro que aceito participar do estudo, sabendo que tenho liberdade de recusar responder qualquer questionamento sem que haja nenhum tipo de prejuízo seja ele físico, psicológico ou financeiro bem como de retirar meu consentimento a qualquer momento. Este termo foi revisado e aprovado pelo Comitê de Ética em Pesquisa do Instituto de Ciências Humanas da Universidade de Brasília - CEP/IH. As informações dos direitos do sujeito da pesquisa podem ser obtidas através do e-mail do CEP/IH: cep_ih@unb.br.

Brasília , de de 


\section{CARTA DE REVISÃO ÉTICA}

O presente projeto desenvolve-se em contexto educacional, no horário em que os participantes frequentam a escola, estando às atividades previstas de acordo com a rotina acadêmica. Não existe nenhuma atividade que propicie situação de esforço para a além do que o participante desempenha em sua prática escolar, sendo permitida a interrupção e a retomada da atividade em tempo posterior. Por essa razão, não depreendemos riscos para os participantes. No entanto, consideramos que as atividades realizadas, por promoverem a reflexão sobre o conhecimento da língua portuguesa na comparação com a Língua Brasileira de Sinais (LIBRAS), podem contribuir para o desenvolvimento acadêmico dos participantes.

Hely César Ferreira 


\section{CARTA DE ENCAMINHAMENTO}

Ao Comitê de Ética em Pesquisa do Instituto de Ciências Humanas Universidade de Brasília

Senhor(a) Coordenador(a),

Eu, Hely César Ferreira, RG no MG-10.561.776 PC/MG, encaminho o projeto de pesquisa intitulado " $A$ interlíngua de surdos aprendizes de português como segunda língua (L2): Uma análise da expressão sintática da estrutura argumental" para revisão ética por parte deste Comitê.

Natureza do projeto: Projeto de dissertação de mestrado em Linguística

Instituição a qual o projeto está vinculado: Programa de pós-graduação em Linguística da Universidade de Brasília.

Pesquisador (a) responsável: Hely César Ferreira Link para o lattes:

http://buscatextual.cnpq.br/buscatextual/visualizacv.do?id=K4906264P8

E-mail pra contato: helycesar247@gmail.com

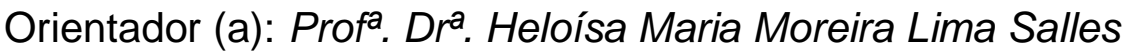

Link para

0

lattes:

http://buscatextual.cnpq.br/buscatextual/visualizacv.do?id=K4784178D1

E-mail pra contato: heloisasalles@gmail.com

Equipe de pesquisa: Hely César Ferreira

http://buscatextual.cnpq.br/buscatextual/visualizacv.do?id=K4906264P8

Instituição onde será realizada a pesquisa: Escola para Surdos "Dulce de Oliveira"

Início da pesquisa/fase de coleta de dados: Outubro/2015.

Eu me comprometo a iniciar a pesquisa/fase de coleta de dados apenas quando houver a aprovação ética de meu projeto de pesquisa por parte do Comitê de Ética em Pesquisa do Instituto de Ciências Humanas $(\mathrm{CEP} / \mathrm{lH})$. 


\section{Termo de Consentimento Livre e Esclarecido}

Você está sendo convidado a participar da pesquisa " $A$ interlíngua de surdos aprendizes de português como segunda língua (L2): Uma análise da expressão sintática da estrutura argumental', de responsabilidade de Hely César Ferreira, aluno(a) de mestrado da Universidade de Brasília. O objetivo desta pesquisa é contribuir para os estudos gramaticais do português e da LSB; examinar a interlíngua de surdos, observando como expressam os argumentos internos e externos dos verbos nas frases, considerando a interferência da $L 1$ na interlíngua. Assim, gostaria de consultá-lo(a) sobre seu interesse e disponibilidade de cooperar com a pesquisa.

Você receberá todos os esclarecimentos necessários antes, durante e após a finalização da pesquisa, e lhe asseguro que o seu nome não será divulgado, sendo mantido o mais rigoroso sigilo mediante a omissão total de informações que permitam identificá-lo(a). Os dados provenientes de sua participação na pesquisa, tais como questionários, entrevistas, fitas de gravação ou filmagem, ficarão sob a guarda do pesquisador responsável pela pesquisa.

A coleta de dados será realizada por meio de atividades escritas em Português a partir de um tema proposto livre e comum, serem aplicadas aos participantes surdos matriculados da Escola para Surdos "Dulce de Oliveira" em Uberaba/MG. É para estes procedimentos que você está sendo convidado a participar. Sua participação na pesquisa não implica em nenhum risco.

Espera-se com esta pesquisa possa melhorar a qualidade de análises da produção de sentenças escritas em Língua Portuguesa pelos informantes de LSB para verificar se há a variabilidade de argumentos interno e externo nas sentenças produzidas por surdos como segunda língua, considerando a interferência da L1 na interlíngua.

Sua participação é voluntária e livre de qualquer remuneração ou benefício. Você é livre para recusar-se a participar, retirar seu consentimento ou interromper sua participação a qualquer momento. A recusa em participar não irá acarretar qualquer penalidade ou perda de benefícios.

Se você tiver qualquer dúvida em relação à pesquisa, você pode me contatar através do telefone/ celular: (34)9207-3248 ou pelo e-mail helycesar247@gmail.com.

A equipe de pesquisa garante que os resultados do estudo serão devolvidos aos participantes por meio de apresentação em Seminários de Pesquisas em dias e horários organizados pelo Programa de Pós-Graduação (PPGL), na própria universidade, sendo aberto ao público interessado, podendo ser publicados posteriormente na comunidade científica.

Este projeto foi revisado e aprovado pelo Comitê de Ética em Pesquisa do Instituto de Ciências Humanas da Universidade de Brasília - CEP/IH. As informações com relação à assinatura do TCLE ou os direitos do sujeito da pesquisa podem ser obtidos através do e-mail do CEP/lH cep_ih@unb.br.

Este documento foi elaborado em duas vias, uma ficará com o(a) pesquisador(a) responsável pela pesquisa e a outra com o senhor(a).

Assinatura do (a) participante

Assinatura do (a) pesquisador (a)

Brasília, de de 


\section{ACEITE INSTITUCIONAL}

$\mathrm{O}$ (A) Sr./Sra. Florence Alves Pereira de Queiroz, diretora do(a) Escola para Surdos "Dulce de Oliveira", está de acordo com a realização da pesquisa A interlíngua de surdos aprendizes de português como segunda língua (L2): Uma análise da expressão sintática da estrutura argumental, de responsabilidade do(a) pesquisador(a) Hely César Ferreira aluno(a) de mestrado no Departamento de Linguística, Português e Línguas Clássicas LIP e Programa de Pós-graduação em Linguística- PPGL da Universidade de Brasília, realizado sob orientação de Profạ. Drạ. Heloísa Maria Moreira Lima Salles, após revisão e aprovação pelo Comitê de Ética em Pesquisa do Instituto de Ciências Humanas da Universidade de Brasília - CEP/IH.

O estudo envolve a realização de atividades escritas em Português a partir de um tema proposto livre e comum, a serem aplicadas aos participantes surdos matriculados na Escola para Surdos "Dulce de Oliveira" em Uberaba/MG. A pesquisa terá a duração de dois meses, com previsão de início em Outubro de 2015 e término em Novembro de 2015.

Eu, Florence Alves Pereira de Queiroz, diretora do(a) Escola para Surdos "Dulce de Oliveira", declaro conhecer e cumprir as Resoluções Éticas Brasileiras, em especial a Resolução CNS 196/96. Esta instituição está ciente de suas co-responsabilidades como instituição co-participante do presente projeto de pesquisa, e de seu compromisso no resguardo da segurança e bemestar dos sujeitos de pesquisa nela recrutados, dispondo de infra-estrutura necessária para a garantia de tal segurança e bem-estar.

Brasília, de de 20

Nome do(a) responsável pela instituição
Assinatura e carimbo do(a) responsável pela instituição 


\section{Termo de Autorização para Utilização de Imagem e Som de Voz para fins de pesquisa}

$\mathrm{Eu}$, , autorizo a utilização da minha imagem e som de voz, na qualidade de participante/entrevistado(a) no projeto de pesquisa intitulado $A$ interlíngua de surdos aprendizes de português como segunda língua (L2): Uma análise da expressão sintática da estrutura argumental, sob responsabilidade de Hely César Ferreira vinculado(a) ao/à Programa de Pós-Graduação em Linguística da Universidade de Brasília.

Minha imagem e som de voz podem ser utilizadas apenas para em forma de filme ou fotografia exclusivamente para fins científicos e de estudos, em livros, artigos, slides ou transparências, em favor exclusivamente da pesquisa, obedecendo ao que está previsto nas Leis que resguardam os direitos das pessoas com deficiência (Decreto № 3.298/1999, alterado pelo Decreto №5.296/2004).

Tenho ciência de que não haverá divulgação da minha imagem nem som de voz por qualquer meio de comunicação, sejam elas televisão, rádio ou internet, exceto nas atividades vinculadas ao ensino e a pesquisa explicitadas acima. Tenho ciência também de que a guarda e demais procedimentos de segurança com relação às imagens e sons de voz são de responsabilidade do(a) pesquisador(a) responsável.

Deste modo, declaro que autorizo, livre e espontaneamente, o uso para fins de pesquisa, nos termos acima descritos, da minha imagem e som de voz.

Este documento foi elaborado em duas vias, uma ficará com o(a) pesquisador(a) responsável pela pesquisa e a outra com o(a) participante.

Brasília, de de 


\section{TERMO DE RESPONSABILIDADE PELO USO DE INFORMAÇÕES E CÓPIAS DE DOCUMENTOS PARA FINS DE PESQUISA}

Hely César Ferreira, portador(a) do documento de identificação de no $M G$ 10.561.776 / PC MG e do CPF no 036.012.626-06, domiciliado(a) à(ao)/na(no) Rua Coronel Manoel Borges, 511 - Bairro Mercês, Uberaba/MG.

DECLARA estar ciente:

a) De que os documentos aos quais solicitou acesso e/ou cópias são custodiados pelo(a) Escola para Surdos "Dulce de Oliveira";

b) Da obrigatoriedade de, por ocasião da divulgação, se autorizada, das referidas reproduções, mencionar sempre que os respectivos documentos em suas versões originais pertencem ao acervo do/da Escola para Surdos "Dulce de Oliveira";

c) De que as cópias dos documentos objetos deste termo não podem ser repassadas a terceiros;

d) Das restrições a que se referem os art. 4 e 6 da Lei n8.159 de 08.01.1991 (Lei de Arquivos); da Lei o 9610, de 19.02.1998 (Lei de Direitos Autorais); dos art. 138 e 145 do Código Penal, que prevê os crimes de calúnia, injúria e difamação; bem como da proibição, decorrente do art. 5ㅇ, inciso X, da Constituição da República Federativa do Brasil, de 1988, de difundir as informações obtidas que, embora associadas a interesses particulares, digam respeito à honra e à imagem de terceiros;

e) De que a pessoa física ou jurídica, responsável pela utilização dos documentos, terá inteira e exclusiva responsabilidade, no âmbito civil e penal, a qualquer tempo, sobre danos materiais ou morais que possam advir da divulgação das informações contidas nos documentos bem como do uso das cópias fornecidas, eximindo, consequentemente, de qualquer responsabilidade, Escola para Surdos "Dulce de Oliveira".

DECLARA igualmente que as informações e as cópias fornecidas serão utilizadas exclusivamente por Hely César Ferreira para fins de pesquisa no âmbito do projeto "A interlíngua de surdos aprendizes de português como segunda língua (L2): Uma análise da expressão sintática da estrutura argumental" vinculado ao/à Programa de Pós-Graduação em Linguística da Universidade de Brasília.

Brasília, de de 2015.

Assinatura do(a) pesquisador(a) 